INTER NATIONAL MONETARY FUND

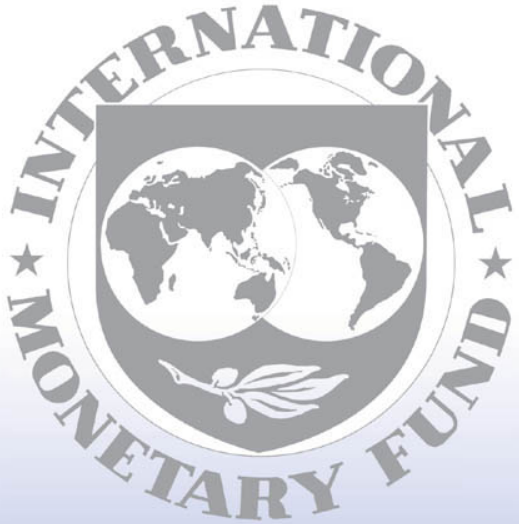

Staff

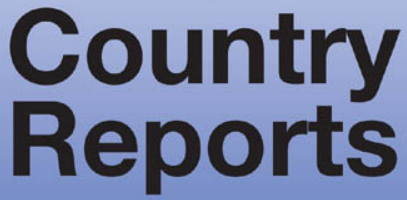




\title{
Bosnia and Herzegovina: Staff Report for the First Review Under the Stand-By Arrangement
}

The following documents have been released and are included in this package:

- The staff report, prepared by a staff team of the IMF, following discussions that ended on March 31, 2010 with the officials of Bosnia and Herzegovina on economic developments and policies. Based on information available at the time of these discussions, the staff report was completed on March 18, 2010. The views expressed in the staff report are those of the staff team and do not necessarily reflect the views of the Executive Board of the IMF.

- $\quad$ A Press Release

- $\quad$ A statement by the Executive Director for Bosnia and Herzegovina

The document(s) listed below will be separately released.

Letter of Intent sent to the IMF by the authorities of Bosnia and Herzegovina*

Technical Memorandum of Understanding*

*Also included in Staff Report

The policy of publication of staff reports and other documents allows for the deletion of market-sensitive information.

\author{
Copies of this report are available to the public from \\ International Monetary Fund • Publication Services \\ $70019^{\text {th }}$ Street, N.W. • Washington, D.C. 20431 \\ Telephone: (202) 623-7430 • Telefax: (202) 623-7201 \\ E-mail: publications@imf.org Internet: http://www.imf.org
}

\section{International Monetary Fund Washington, D.C.}




\title{
INTERNATIONAL MONETARY FUND
}

\author{
BOSNIA AND HERZEGOVINA
}

\section{First Review Under the Stand-By Arrangement}

Prepared by the European Department

(In consultation with other departments)

Approved by Adam Bennett and Dominique Desruelle

March 8, 2010

Stand-By Arrangement (SBA). A 36-month, SDR 1,014.6 million (about US\$1.6 billion, 600 percent of quota) SBA was approved by the Executive Board on July 8, 2009 (Country Report No. 09/226). An initial purchase of SDR 182.6 million (108 percent of quota) was made following the Board meeting. The program foresees a purchase of SDR 121.75 million (72 percent of quota) following the completion of this review after March 10, 2010.

Program status. All end-September 2009 and end-December 2009 quantitative performance criteria were met. An end-August 2009 structural benchmark on parliamentary approval of rebalanced entity budgets was also met, the continuous benchmark on the publication of fiscal statistics was partially met with a delay, and all other benchmarks pertaining to fiscal and financial sector reforms were met albeit with some delay. However, the program's fiscal deficit objective for 2009 was exceeded because of revenue shortfalls and, under unchanged policies, the fiscal deficit for 2010 would have exceeded the program's objective. On the basis of the corrective actions described in the attached letter of intent (LOI) and in the report, staff support the authorities' request for completion of the first review.

Discussions. During November 4-20, the staff team met with: (i) at the State level: Member of the Presidency Komšić, the Chair of the Council of Ministers Špirić, the Minister of Finance and Treasury Vrankić, and Central Bank Governor Kozarić; (ii) in the Federation of Bosnia and Herzegovina: Prime Minister Mujezinović and Minister of Finance Bevanda; and (iii) in the Republika Srpska: Prime Minister Dodik and Minister of Finance Džombić. The Fund staff also met with other senior officials, High Representative Inzko, ambassadors, trade unions, and representatives of the private sector.

Staff. The mission team comprised Mr. Christou (head); Mr. Iossifov (both EUR), Ms. Karpowicz (FAD), Mr. Darbar (MCM), and Ms. Khachatryan (SPR). Mr. Cuc (resident representative) assisted the mission and Ms. Kinoshita (EUR) supported the mission's work from HQ. Mr. Tomić (OED) attended all policy meetings. The mission coordinated closely with World Bank staff on structural issues. 


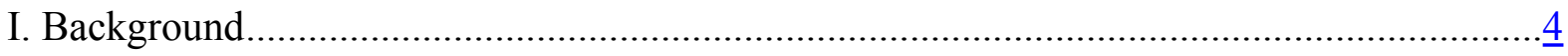

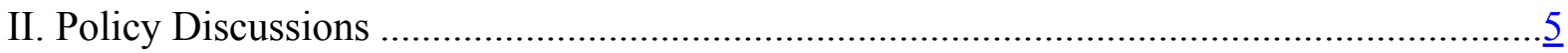

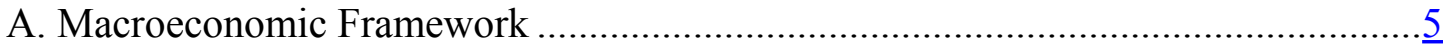

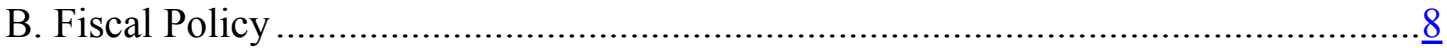

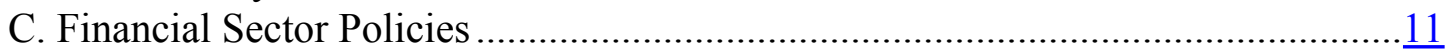

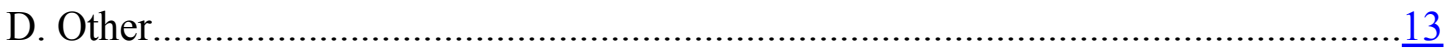

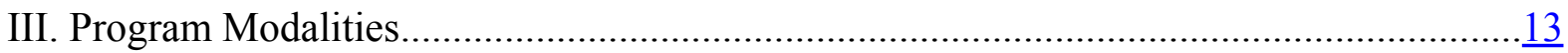

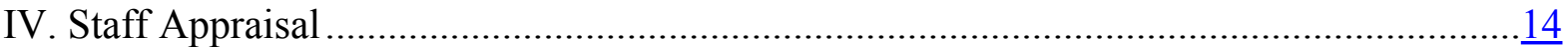

Attachments

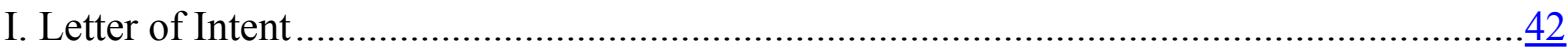

II. Technical Memorandum of Understanding..................................................................

Boxes

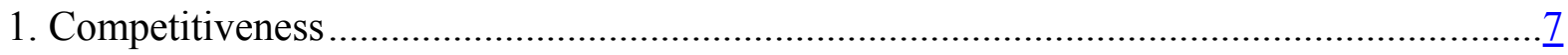

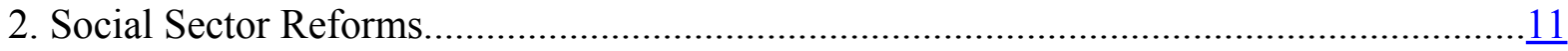

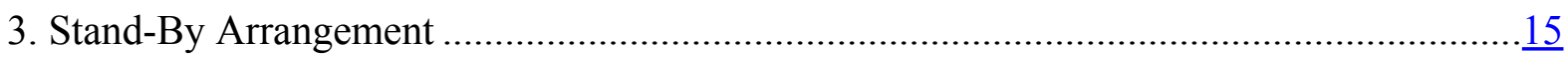

Figures

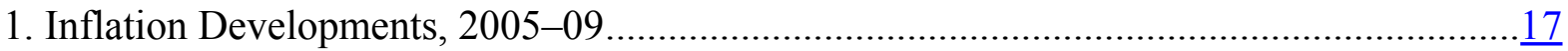

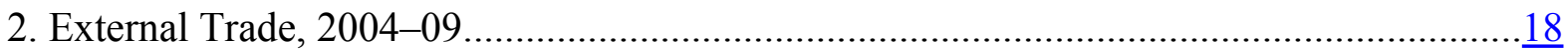

3. Central Bank's Foreign Assets and Commercial Bank Reserves, 2008-09 ………............19

Tables

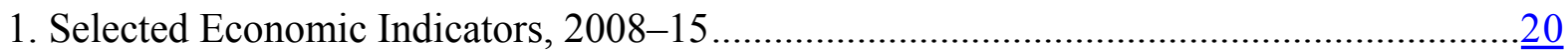

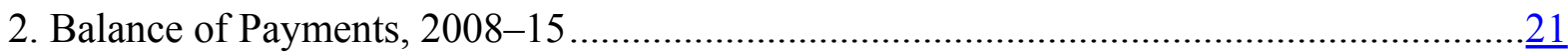

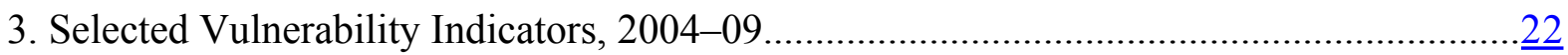

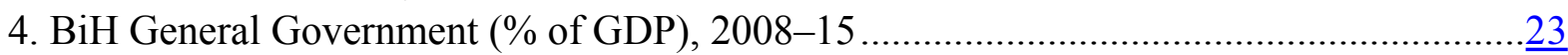

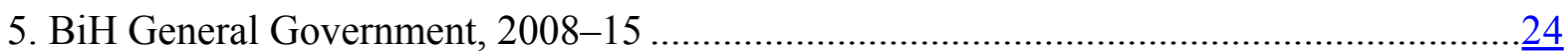

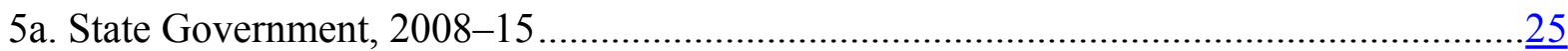

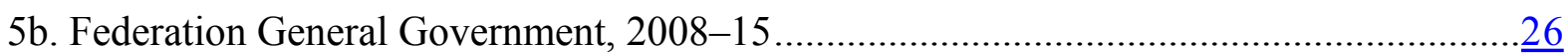

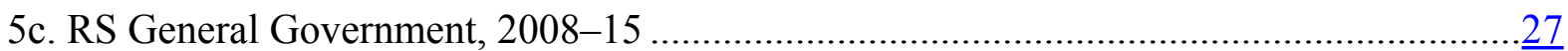

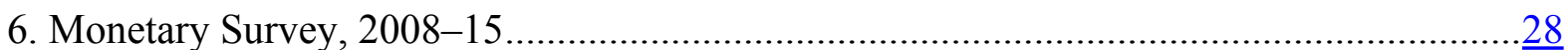

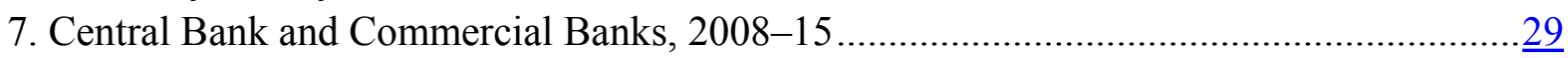

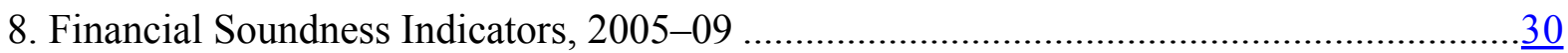

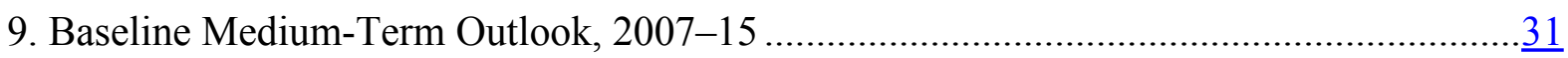

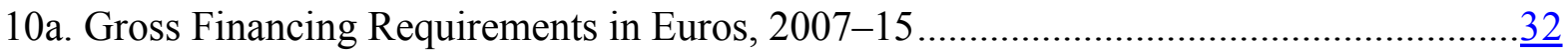

10b. Gross Financing Requirements in Percent of GDP, 2007-15 ………………............... 
11. Indicators if Capacity to Repay the Fund, 2008-15 .....................................................

12. Performance Criteria Under the 2009-12 SBA, 2009 ....................................................

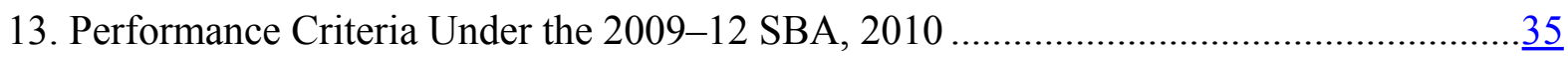

14. Performance for the First Review Under the 2009-12 SBA ……………………............

15. Schedule of Purchases Under the SBA, 2009-12 ……...............................................

Appendix Figures

1. External Debt Sustainability: Bound Tests.................................................................

2. Public Debt Sustainability: Bound Tests …………....................................................

Appendix Tables

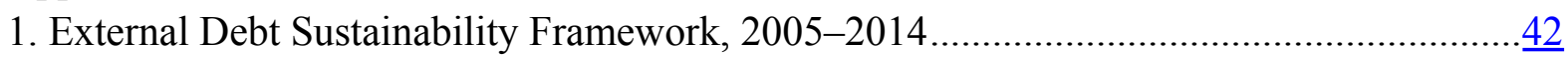

2. Public Sector Debt Sustainability Framework, 2005-14 ……………………………....... 


\section{BACKGROUND}

1. Macroeconomic developments remain broadly in line with program projections, except for a larger-than-anticipated contraction of the current account deficit.

Following several years of strong growth increasingly accompanied by external and internal imbalances, economic activity in Bosnia and Herzegovina $(\mathrm{BiH})$ began to decelerate in late 2008. The downturn spread quickly across all sectors in 2009 , with the exception of refined petroleum and electricity production in Republika Srpska (RS). The precipitous drop in demand for BiH's exports and the drying up of foreign direct investment triggered a sharp decline in private investment. Tightening credit conditions and the ensuing uncertainty put a further squeeze on spending on capital goods and consumer durables.

Private consumption of non-durables softened but to a lesser extent, on the back of moderate growth in wages and social benefits. Core inflation has remained stable while headline
BIH: Leading Indicators, December 2009 (percent change year-to-date over corresponding period in previous year)

\begin{tabular}{lrl}
\hline Industrial production & & \\
$\quad$ Federation & -11.6 & \\
RS & 19.0 & 1 \\
Gross wage, all sectors (12-month growth rate) & 4.8 & 2 \\
Net wage, all sectors (12-month growth rate) & 1.9 & 2 \\
Retail trade (Federation) & -12.4 & \\
Value-added tax (net of refunds) & -9.3 & -24.4 \\
Imports & -39.0 & -39.5 \\
Capital goods & -4.4 & -17.9 \\
Durable consumer goods & -52.9 & 3 \\
Non-durable consumer goods & -3.8 & \\
Exports & & \\
Foreign direct investment & & \\
Credit to private sector (12-month growth rate) & & \\
\end{tabular}

${ }^{1}$ Figure affected by the re-start of a large refinery in late 2008. ${ }^{2}$ Nov, 2009

3 Jan - Sep, 2009. inflation turned negative with declines in food and energy prices (Figure 1). The trade deficit has been narrowing faster than anticipated leading to a sharp reduction in the current account deficit (Figure 2).

\section{Financial market stress has eased, reflecting an improvement in market}

sentiment. The currency board (with the convertible marka pegged to the euro) continues to enjoy strong support and remains a key macroeconomic policy anchor. Meanwhile, there are signs of a return of confidence in the banking system: nongovernment deposits have been flowing back, which has allowed foreign parent banks to scale down their support for local subsidiaries. Foreign reserves of the Central Bank of Bosnia and Herzegovina (CBBH) have strengthened by 9 percent from the June 2009 lows, in large part owing to the first purchase under the SBA and SDR allocations (Figure 3). Commercial banks appear liquid and adequately funded. Nevertheless, the general Bosnia and Herzegovina: Commercial Banks' Funding Sources (cumulative change since October 2008)

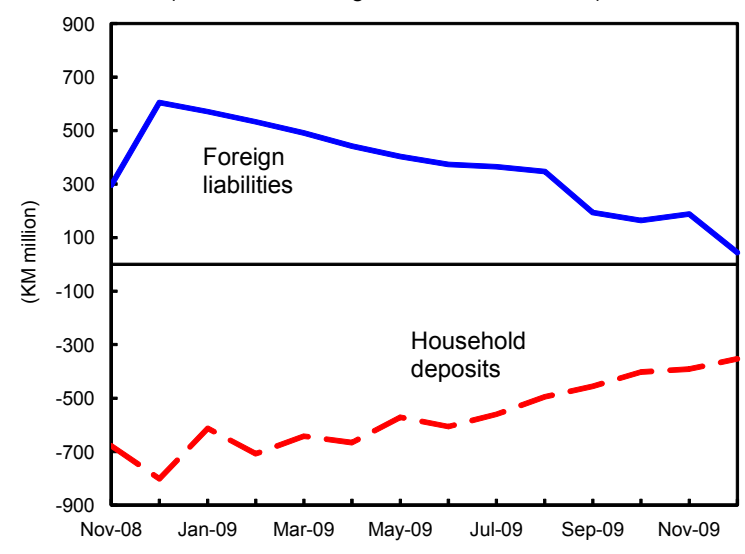
worsening of economic environment and stricter lending standards have brought private 
sector credit growth to a halt (3.8 percent yo-y decline in December 2009 compared with a 21 percent y-o-y increase in December 2008). With the downturn taking its toll on the financial health of enterprises and households, the system-wide NPL ratio has been edging up, while increased provisioning and lower activity has hurt bank profitability.

BiH: Financial Soundness Indicators, 2008-09

\begin{tabular}{lrr}
\hline & 2008 & 2009 \\
& Dec. & Dec. \\
\hline Tier 1 capital to risk-weighted assets & 12.0 & 12.4 \\
Nonperforming loans to total loans & 3.1 & 5.8 \\
Return on equity & 4.3 & 1.1 \\
Liquid assets to short- term financial liabilities & 51.8 & 52.9 \\
Net open position & 6.2 & 1.7 \\
\hline Source: CBBH. & &
\end{tabular}

Banks have reacted by raising interest rates on loans, further tightening credit conditions.

3. External financing has been somewhat better than expected. Non-bank private inflows - including FDI, and trade and private non-bank credits - were stronger than anticipated through September 2009. This was partly offset by lower-than-expected government foreign borrowing, and lower rollover rate for banks — 91 percent against the program projection of 100 percent. Gross official international reserves were above program projections by $€ 242$ million at end-December 2009 .

4. The difficult political situation complicates policymaking. Since the signing of the Stabilization and Association Agreement with the EU in June 2008, little progress has been made on reforms necessary for accession. Moreover, recent attempts by the international community to advance constitutional reform appear to have stalled, and conflicting views on the future makeup of the country suggest still little common ground. In addition, policymakers are keeping an eye on the October 2010 general elections.

5. Nevertheless, early program performance has been promising. All end-September and end-December 2009 quantitative performance criteria, an end-August 2009 structural benchmark on parliamentary approval of rebalanced entity budgets, and an end-February 2010 benchmark on the establishment of universal membership in the Deposit Insurance Agency were met (Tables 12 and 14). The authorities also took steps toward strengthening the financial sector, and reforming the budget process and the system of rights-based benefits-all corresponding structural benchmarks were met, albeit with some delay. Finally, substantial progress was made on improving fiscal data reporting, although only partial general government data have been published with a delay (continuous benchmark).

\section{Policy Discussions}

\section{A. Macroeconomic Framework}

6. The approved program's macroeconomic framework remains broadly valid:

- Real GDP is estimated to have contracted by $3 \frac{1}{2}$ percent in 2009 (compared to a 3 percent decline in the program). With external demand already showing signs of a recovery, output is set to grow modestly by $1 / 2$ percent in 2010 . 
Bosnia and Herzegovina: Key Macroeconomic Indicators, 2008-10

(In percent of GDP, unless otherwise indicated)

\begin{tabular}{lrrrrrrr}
\hline & 2008 & \multicolumn{2}{c}{2009} & & \multicolumn{2}{c}{2010} \\
& & & $\begin{array}{c}\text { EBS/09/94 } \\
\text { Prog. }\end{array}$ & Proj. & $\begin{array}{c}\text { EBS/09/94 } \\
\text { Prog. }\end{array}$ & Prog. \\
\hline Real GDP growth (percent) & 5.4 & -3.0 & -3.4 & & 0.5 & 0.5 \\
CPI (change in percent; average) & 7.4 & 1.6 & -0.4 & & 2.3 & 1.6 \\
Credit to the private sector growth (percent) & 20.8 & & & -3.0 & & 4.0 & -2.7 \\
Current account balance & -14.9 & -9.7 & -7.5 & & -9.6 & -7.3 \\
General government balance & -4.8 & -4.7 & -5.3 & & -4.0 & -4.5 \\
Reserve cover (months of imports) & 5.7 & 4.7 & 5.3 & & 4.5 & 5.4 \\
Gross external debt & 48.9 & 52.4 & 53.0 & & 56.7 & 58.3 \\
Total public debt & 30.8 & 34.7 & 33.4 & & 39.8 & 38.1 \\
\hline
\end{tabular}

Sources: Bosnian authorities; and IMF staff estimates and projections.

- Inflation is expected to be somewhat lower than in the program, and remain low in line with inflation in the euro area.

The current account deficit has been narrowing faster than anticipated and the trend decline is expected to persist over the medium term, thus bringing the deficit to a level considered sustainable over the medium term (Appendix Table 1). This reflects the projected permanent decline in domestic absorption, and imports, relative to GDP (as in the rest of the region), driven by fiscal consolidation and the end of the rapid credit growth funded by foreign savings. Continued strong export performance should be underpinned by an assumed robust recovery in the growth of BiH's trading partners, adequate external

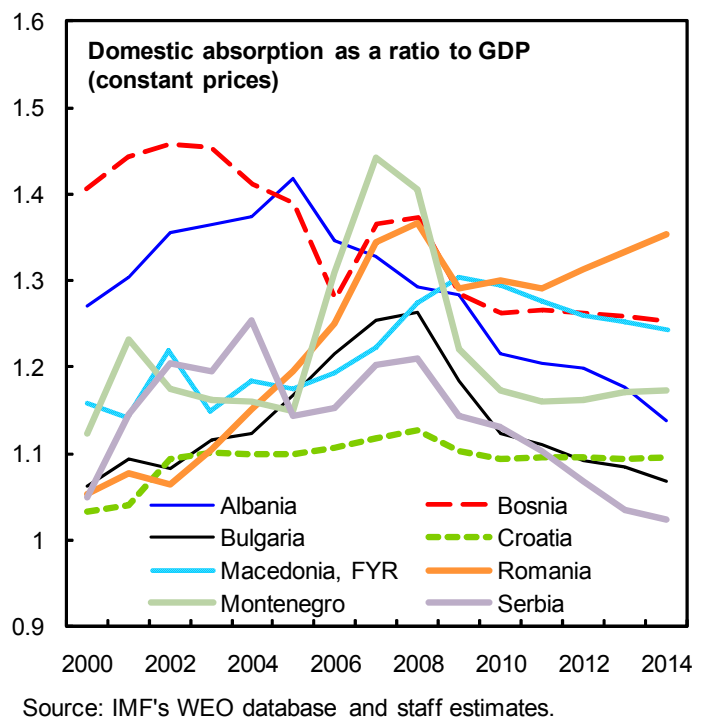
competitiveness (Box 1) and ongoing reforms to enhance it further, and a shift toward higher value-added exports.

The revised outlook for the capital and financial accounts reflects slower privatization in the Federation and lower debt rollover from parent banks to subsidiaries. Over the medium term, the program assumes that the entities will be able to service their external debt in part by privatization receipts (Federation) and by accessing international capital markets (RS). Official reserves are expected to remain adequate at 4-5 months of next-year imports. 


\section{Box 1. Bosnia and Herzegovina: Competitiveness}

Real effective exchange rate (REER) developments indicate stable (based on relative consumer prices) to improving (based on relative unit labor costs) external competitiveness of $\mathrm{BiH}$ that has underpinned its growing export market shares. A closer look at the evolution of unit labor cost shows a decline in employment, while output and wages have been increasing. At the same time, BiH's export structure has shifted toward higher-value added manufacturing goods. The growth of the more capital-intensive export sectormetal and aluminumimplies an upward

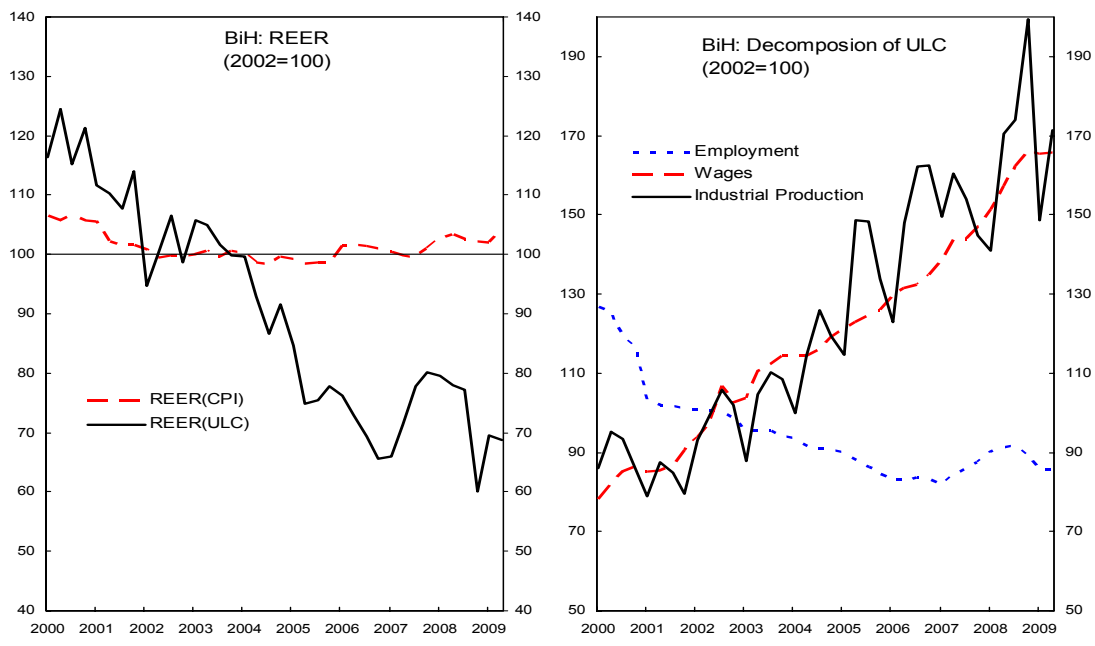
shift in the capital-labor ratio over time. This argues for caution in interpreting the otherwise positive trends in competitiveness based on labor cost indicators.

Private sector growth in $\mathrm{BiH}$ is hampered by various structural impediments. According to the World Bank Doing Business Report 2010, a cross-country ranking of business environment indicators shows BiH's sub-par performance relative to neighboring countries (116 out of 183 countries). This conclusion was confirmed in the mission's meetings with private sector representatives. According to them, key factors impeding FDI and higher access of companies to foreign markets include: (i) political instability; (ii) complicated and "expensive" bureaucracy; (iii) lack of clear vision for economic development; (iv) corruption and weak legislative framework; and (v) poor quality control (i.e., local certification and standardization). Substantial opportunities lie in enhanced productivity via bigger investment in R\&D and human capital.

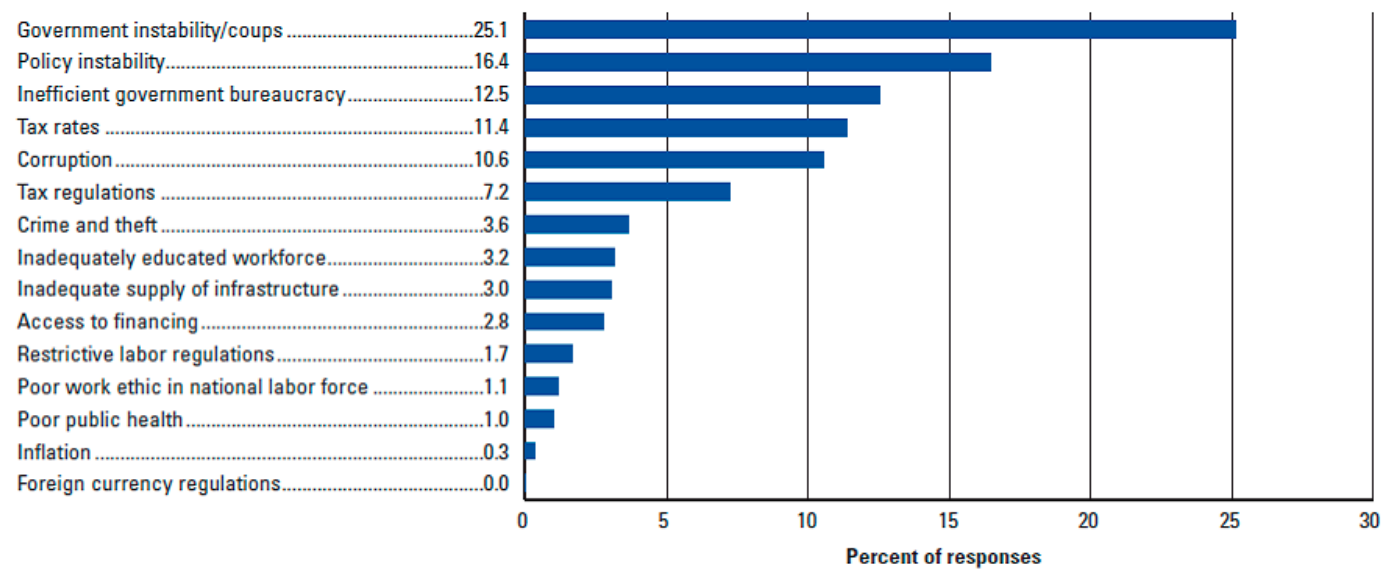

Note: From a list of 15 factors, respondents were asked to select the five most problematic for doing business in their country/economy and to rank them between 1 (most problematic) and 5 . The bars in the figure show the responses weighted according to their rankings.

Source: World Economic Forum, Competitiveness Report 2009-2010. 
7. Risks to the outlook appear balanced. High frequency indicators suggest that the economy may be bottoming out and that growth is likely to pick up in early 2010. Also, indications of a faster economic recovery in the EU support better prospects for external demand and private capital inflows. However, downside risks remain. With nonperforming loans still edging upward, banks need to maintain adequate capital cushions - something that may act as a drag on the projected recovery in bank credit growth. Moreover, the difficult political situation could hamper program implementation.

\section{B. Fiscal Policy}

\section{The 2009 fiscal deficit objective was exceeded and the fiscal outlook has}

worsened. Preliminary data indicate that, on account of revenue shortfalls and despite lowerthan-programmed expenditures, the 2009 general government deficit reached 5.3 percent of GDP compared with the program target of 4.7 percent. Overruns on wages and transfers were offset by strict control over other current spending and by underperformance of the capital budget. The endSeptember and end-December 2009 targets for net bank financing were met, as the entities partially replaced expected budget-support funds from the IMF and the World Bank with funds from the SDR allocations, and increased float (by 1 percent of GDP) to finance the deficit. However, under

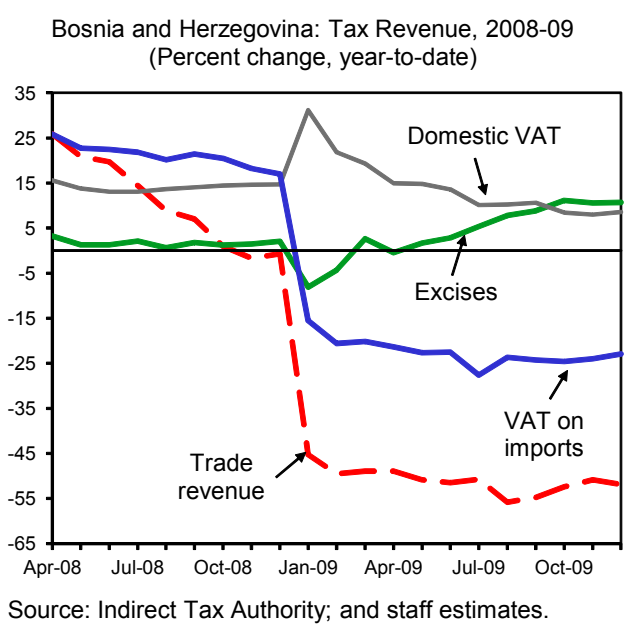
unchanged policies, the fiscal deficit would reach 6 percent in 2010, thus putting fiscal sustainability at risk.

\section{Against this backdrop, the revised fiscal} strategy accommodates a slightly higher deficit for Bosnia and Herzegovina: General Government Fiscal Balance, in percent of GDP 2010, while advancing structural fiscal reforms. The fiscal balance has been revised to $4 \frac{1}{2}$ percent in 2010 (from the original 4 percent), with approval of all 2010 budgets and supporting legislation prior actions for the review (met). Structural fiscal reforms aim at putting public finances on a sustainable footing by helping reduce the public debt-to-GDP ratio to below 30 percent over the medium term (Appendix Table 2). ${ }^{1}$ On the revenue side, further

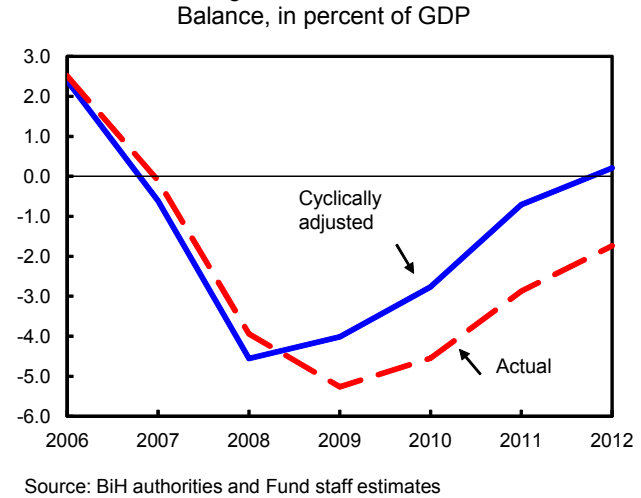

\footnotetext{
${ }^{1}$ Keeping the primary fiscal deficit at its pre-program level over 2009-14 (no adjustment scenario) would have doubled the public debt-to-GDP ratio.
} 
increases in tobacco excises to bring them more in line with the EU have already been approved. As for expenditure:

\begin{tabular}{|c|c|c|c|c|c|c|c|}
\hline & \multirow[b]{2}{*}{2006} & \multirow[b]{2}{*}{2007} & \multirow[b]{2}{*}{2008} & \multicolumn{2}{|l|}{2009} & \multicolumn{2}{|l|}{2010} \\
\hline & & & & $\begin{array}{c}\text { Prog. } \\
\text { EBS/09/94 }\end{array}$ & Proj. & $\begin{array}{c}\text { Prog. } \\
\text { EBS/09/94 }\end{array}$ & Prog. \\
\hline Revenue and grants & 47.5 & 47.2 & 45.5 & 45.0 & 44.1 & 45.9 & 44.3 \\
\hline Tax & 38.4 & 38.2 & 37.6 & 36.9 & 36.7 & 37.4 & 37.1 \\
\hline Non-tax & 6.5 & 6.1 & 5.7 & 5.8 & 5.6 & 5.5 & 5.3 \\
\hline Grants & 2.6 & 3.1 & 2.2 & 2.3 & 1.8 & 3.0 & 1.9 \\
\hline $\begin{array}{l}\text { Expenditure } \\
\text { of which }\end{array}$ & 45.3 & 47.3 & 50.3 & 49.7 & 49.4 & 49.9 & 48.8 \\
\hline $\begin{array}{l}\text { Current spending } \\
\text { of which }\end{array}$ & 39.1 & 40.6 & 41.5 & 42.1 & 42.9 & 41.8 & 42.4 \\
\hline Wage bill & 11.1 & 11.4 & 12.0 & 12.4 & 12.7 & 12.5 & 12.3 \\
\hline Goods and services & 10.0 & 9.5 & 9.1 & 9.8 & 9.9 & 9.5 & 10.1 \\
\hline Subsidies and transfers & 13.7 & 15.8 & 16.3 & 16.1 & 17.2 & 15.9 & 16.6 \\
\hline Capital spending & 6.1 & 6.6 & 6.5 & 7.1 & 6.0 & 7.9 & 6.2 \\
\hline Fiscal balance & 2.2 & -0.1 & -4.8 & -4.7 & -5.3 & -4.0 & -4.5 \\
\hline Primary balance & 2.9 & 0.5 & -4.3 & -3.8 & -4.7 & -3.0 & -3.9 \\
\hline
\end{tabular}

- $\quad$ State. Following wage reductions in 2009, the State will freeze wages at the 2009 levels. Substantial savings from past years will support an increase in employment in newly-created institutions and higher capital investment

- Federation. The 2010 budget targets reductions in recurrent expenditure, thus allowing for an increase in investment expenditure ( 0.3 percent of GDP). A new civil service wage law will be prepared (end-March 2010 structural benchmark), which, in addition to rationalizing the wage bill, will also improve transparency by consolidating a large number of allowances into the base wage. Moreover, substantial savings are envisaged in transfers due to the elimination of special unemployment benefits for demobilized soldiers effective May 1, 2010 (prior action-met), the implementation of eligibility audits for civil and war benefit recipients, and strict control over pensions provided with favorable terms (LOI, $\mid 20-24)$.

- $\quad \boldsymbol{R S}$. Spending on wages will be rationalized, including through reductions in wages of the highest paid government officials by 15 percent and of employees in public administration by 10 percent. Although spending on untargeted transfers to individuals has already been reduced substantially, the continuation of eligibility audits will yield further savings; and the first results of the pension reform will already be evident in 2010 (LOI, $\mid 25-27)$.

- $\quad$ State and Entity authorities stand ready to take further compensatory measures, if needed, focusing mainly on the expenditure side.

10. Despite larger deficits in 2009-10, the envisaged exit strategy from the use of Fund resources for the budget remains appropriate. Accommodating larger deficits in 
2009-10 will widen the fiscal financing gap only slightly, and the additional financing needs will be met through bank financing. Over the medium term, the ongoing fiscal adjustment and the structural fiscal reforms envisaged under the program, along with a return of confidence and improved external conditions, would allow an exit from temporary budget financing using Fund resources. To this end, the Federation should be able to finance its transition to a more sustainable fiscal path through privatization proceeds, while the RS would tap international capital markets.

\section{The authorities will undertake a series of structural fiscal reforms.}

- Rights-based benefits. An action plan to reform the system of rights-based benefitswhich is an end-November 2009 structural benchmark for the Federation-was prepared in consultation with the World Bank and approved by the government on December 14, 2009 (Box 2). Moreover, framework legislation has been enacted by the Federation and the RS (prior action—met), with the objective of rationalizing and streamlining those benefits, and improving targeting (LOI, $\mid 20-21$ and $\mid 27$ ). The authorities have committed to consult with staff on the introduction of new rightsbased benefits.

- Pensions. The authorities plan to initiate reforms of the pensions systems (end-March 2010 structural benchmarks). In the Federation, a new law introducing second and third pillars is under preparation. The RS strategy — which has already been approved by government — aims at modifying the first pillar to ensure medium-term sustainability. Reform elements include efforts to increase contributions (through broadening of the tax base and improving administration) and streamline benefits (by increasing years of contributions and indexing pensions to inflation as opposed to wage growth) (LOI, $\mid 20-21$ and $\ 26$ ).

- Budget process. Albeit with some delay, important first steps have been made by the Federation to improve the budget process: amendments to the Organic Budget Law forbidding passing of unfunded legislation — an end-November 2009 structural benchmark — were approved by government on December 14 and submitted to parliament. To further promote fiscal discipline, and drawing on advice from the Fund, the government will initiate the preparation of a Fiscal Responsibility Law (LOI, ๆ24).

12. The Entity governments are committed to safeguarding public investment and protecting vulnerable groups. Capital spending is projected to increase by 0.2 percent of GDP in 2010 and efforts will be made to improve implementation capacity; also, a number of investment projects that could be executed through public-private partnerships are already in the pipeline. Moreover, the authorities are committed to protect vulnerable groups, by improving the targeting of social benefits, and preserving the financial integrity of the public pensions and unemployment insurance funds. 


\section{Box 2. Bosnia and Herzegovina: Social Sector Reforms}

The proposed Development Policy Loan (DPL) from the World Bank aims to reform public expenditures that have been the main driver of pro-cyclical fiscal policies, notably excessive and regressive social transfers, and a high wage bill. In addition, the program will aim at lowering social contribution rates to encourage formal sector employment and enhance competitiveness and private sector development.

Pillar I of the reform program focuses on social benefits administration, and targeting of social protection programs. Short term measures include the revision of laws that would mandate means-testing for all civilian and war-related benefits, would reduce allowances for medal holders, and eliminate special unemployment benefits to demobilized soldiers.

In the medium term, census of income and property will be carried out to provide the basis for means testing. With a substantial elimination of double-dipping, expenditure on non-insurance social benefits would be reduced to a range of 1 to 2 percent of GDP by 2012 (from about 4 percent of GDP currently).

The public sector wage bill reform contemplated under Pillar II will result in more transparent salary laws that better link pay with responsibility. Wage growth would be contained and the wage bill lowered to give a signal of restraint for private sector settlements thus enhancing external competitiveness.

In support of competitiveness, Pillar III will harmonize the bases for social contributions, reduce health plan contributions and bring indirect taxes in line with EU legislation. Reforms in these areas will follow a number of steps, with the preparatory documents finalized by endyear, and enactment of relevant legislation to occur in 2010-11.

\section{Financial Sector Policies}

\section{The authorities remain vigilant to any signs of stress in the banking system,} which has thus far withstood the impact of the global financial crisis. The capital adequacy ratio has remained stable, partly reflecting the decline in risk-weighted assets in line with the decline in lending growth. Banks have also retained 2008 profits to increase their buffers. Nevertheless, profitability has declined and NPLs have crept up. Going forward, profitability is likely to be weak and NPLs are expected to edge up further. Thus, there was recognition of the need to continuously monitor developments and ensure that commercial banks have a forward looking plan to address any potential deterioration in capital. The authorities are also going to suggest to banks to retain their 2009 profits to further strengthen their capital base (LOI $₫ 29$ ).

\section{The authorities have secured commitments from the parents of the largest} foreign-owned banks toward their continued support to BiH (LOI 930 ). Following meetings in Vienna in June 2009 and in Sarajevo in September 2009 under the European 
Bank Coordination Initiative (EBCI), specific bilateral commitment letters were received from 9 parent banks. The 13 subsidiaries of these banks account for 87 percent of banking sector assets. Parent banks agreed to maintain their exposures at the end-2008 level throughout the program period and to recapitalize their subsidiaries as needed. It was also agreed that a review of these commitments will be undertaken on a semiannual basis.

\section{While exposure commitments of parent banks have been broadly consistent with expectations, lack of comprehensive data does not allow full evaluation of their} exposure commitments. Data for the 9 parents indicate that parent banks' exposure to their subsidiaries has declined by about 7 percent between December 2008 Parent Bank Exposure in BIH (In millions of $\mathrm{KM}$ ) and December 2009. This trend is consistent with balance of payments developments. Nevertheless, banks have maintained liquidity buffers, as nongovernment deposits are flowing back into the system while credit demand remains weak amidst tighter

\begin{tabular}{lrrr}
\hline & Dec '08 & Dec '09 & $\begin{array}{r}\text { Percent } \\
\text { change }\end{array}$ \\
\hline Exposure to subsidiaries & 5,270 & 4,919 & -6.7 \\
All other exposures ${ }^{1}$ & 1,134 & 1,296 & 14.3 \\
Total & 6,405 & 6,215 & -3.0 \\
\hline
\end{tabular}

${ }^{1}$ Partial data for 3 of the 9 banks. lending standards. The decline in parent banks' exposure to subsidiaries was partially offset by an increase in exposure to other entities during the same period. The $\mathrm{CBBH}$ has developed a reporting format that will allow a comprehensive monitoring of overall exposures to $\mathrm{BiH}$ going forward.

16. The program includes steps to ensure banks remain adequately capitalized. To this end, the $\mathrm{CBBH}$ in cooperation with the banking agencies are in the process of conducting stress tests on the subsidiaries participating in the EBCI. The stress tests are based on two macroeconomic scenarios, one relying on the program macroeconomic assumptions and another, more pessimistic scenario. ${ }^{2}$ Going forward, the authorities are expected to finalize the stress tests, discuss the results on a bilateral basis with the banks, and review each institution's capital adequacy as per the commitment under the EBCI (LOI 930 ). Staff urges the $\mathrm{CBBH}$ to continuously monitor vulnerabilities in the banking system in part by conducting top-down stress tests on a regular basis in cooperation with the banking agencies.

\section{Important steps have been made toward strengthening crisis preparedness and} safeguarding financial stability. A Standing Committee for Financial Stability (SCFS) has been established and a Memorandum of Understanding on financial stability, crisis preparedness and management has been signed on December 22, 2009 (end-November 2009

\footnotetext{
2 The stress tests will be conducted in line with the framework of the IMF-led CESE regional stress testing exercise. The authorities also benefited from an MCM TA mission which overlapped with the review mission.
} 
structural benchmark). The SCFS plans to meet at least once every quarter or as necessary to discuss and exchange information related to financial stability. The authorities have also amended the regulation (on October 28, 2009) to allow all banks, regardless of ownership, membership in the deposit insurance scheme (end-February 2010 structural benchmark) (LOI $\llbracket 32$ ).

\section{Other}

18. Substantial progress has been made on improving the quality of statistics (LOI, q33). A coordinating group has been set up, with the task of collecting and consolidating fiscal statistics harmonized with Eurostat and the IMF's Government Finance Statistics guidelines from all levels of government. Albeit with some delay, the group has already published partial general government data for end-September 2009 and end-December 2009 (continuous benchmark). The authorities have stepped up their efforts to ensure that they meet the benchmark without delay in the future.

\section{Program Modalities}

\section{The attached LOI describes the authorities' progress in implementing their} economic program and sets out their commitments for 2010.

- $\quad \mathrm{BiH}$ continues to face sizeable balance of payments financing needs over the next three years. Nevertheless. the Fund arrangement remains adequate to meet BiH's balance of payments needs through 2012, alongside financing commitments from the European Commission and the World Bank. While the estimated external financing needs for 2009-10 have declined somewhat against the backdrop of a faster-thanexpected external adjustment, it is proposed to leave the phasing as initially programmed given the fragility of the stabilization process and uncertainties going forward.

- $\quad$ The first review under the SBA was delayed to give the authorities more time to adopt a number of reforms of rights-based benefits. Since the conditions prescribed by the SBA for the authorities to request the purchase of the tranche that becomes available on March 10, 2010 have been met, the authorities intend to draw the amount available at the completion of the review (SDR 121.75 million), with the entire purchase used for budget support. As noted above, going forward it is envisaged to stick to the program's exit strategy from temporary budget financing using Fund resources.

- New structural conditionality will continue to focus on the fiscal area (Box 3), and it is deemed necessary to address long-standing structural problems and ensure a return of public finances to a sustainable medium-term path. 
20. BiH's capacity to repay the Fund is expected to remain good. The country's excellent record of serving its Fund obligations, the expectation that the program would lay the foundations for the return to a sustainable medium-term growth path, and a strong political commitment to the Fund-supported program provide assurances that $\mathrm{BiH}$ will be able to discharge its Fund obligations in a timely manner. By the end of the SBA, Fund credit outstanding is projected to be 7.6 percent of GDP (28.7 percent of gross reserves).

\section{The updated safeguards assessment of the $\mathrm{CBBH}$ was completed in October}

2009. The assessment found that in general the $\mathrm{CBBH}$ has further improved its safeguards framework by adopting a bank-wide risks assessment methodology, strengthening the internal audit function, and amending the Audit Committees' by-laws. Nevertheless, the authorities have committed to further strengthen the safeguards framework (LOI $\mid 34$ ).

\section{STAFF Appraisal}

22. Initial implementation of Bosnia and Herzegovina's stabilization program has been encouraging. Fiscal restraint and structural fiscal reforms are targeting expenditure categories that led to large imbalances in recent years. Financial sector policies are helping to support adequate liquidity in the banking sector. As a result, the severity of the downturn has been contained, confidence in the currency board maintained, household deposits are recovering, and the international reserve position has strengthened. Early performance under the program has been satisfactory, with all quantitative performance criteria for endSeptember 2009 and end-December 2009 having been met. Structural reforms have progressed, albeit with some delay.

\section{Continued challenges call for the steadfast implementation of strong policies.}

Although the short-term economic and financial outlook has stabilized, strong efforts are still needed to ensure fiscal and external sustainability. Temporary measures now need to yield to more systemic reforms of: rights-based benefits and untargeted transfers; public wages in the Federation; and pension systems. Successful implementation of these reforms requires broad political support and stronger consensus among social partners and the public. 


\section{Box 3. Bosnia and Herzegovina: Stand-By Arrangement}

Access: SDR 1,014.6 million, 600 percent of quota.

Length: 36 months.

Phasing: SDR182.6 million was made available upon the Board's approval of the arrangement to address fiscal and balance of payment needs during the rest of the year. The availability of the second tranche (SDR 87.9 million) is subject to the completion of this (first) review. The ten subsequent quarterly tranches ending in June 2012, will equal SDR 744 million, and be contingent upon completion of further quarterly reviews.

\section{Conditionality}

\section{Quantitative Performance Criteria}

- Ceiling on accumulation of net credit of the banking system to:

$\checkmark$ consolidated general government

$\checkmark$ State government

$\checkmark$ RS consolidated government

$\checkmark$ Federation consolidated government

- Ceiling on new guarantees and the assumption of enterprise debt to banks by the public sector

- Ceiling on accumulation external debt service arrears

- Ceiling on contracting new short-term nonconcessional external debt

- Ceiling on accumulation of domestic arrears of:

$\checkmark$ the State government

$\checkmark$ the RS Government

$\checkmark$ the Federation government

\section{Prior Actions}

- Approve by State and Entity Parliaments 2010 budgets consistent with the program, including supporting legislation

- Enact by Entity Parliaments framework legislation in preparation for the transition to a means-tested system of rights-based benefits (Federation, RS)

- Enact law to eliminate special unemployment benefits granted to demobilized soldiers effective May 1, 2010 (Federation)

\section{Structural Benchmarks}

- Adhere to the Currency Board Arrangement as constituted under the law (Continuous)

- Publish on the State government's web site quarterly consolidated general government accounts with a 5 week lag (Continuous)

- Agree on an action plan acceptable to the World Bank and IMF staffs to reform the system of rightsbased transfers in the Federation (end-November 2009)

- Submit to the Federation Parliament a Law forbidding passing of unfunded legislation (end-November 2009)

- Form a standing committee of financial stability and sign the MoU on financial stability, crisis preparedness and crisis management (end-November 2009)

- The Deposit Insurance Agency to impose a principle of universal membership requirements, including for partially state-owned banks (end-February 2010).

- Carry out eligibility audits for civil and war benefit recipients; publish results (quarterly within 4 weeks after the end of each quarter) of audits, including expected savings from disqualifications (Federation, RS)

(Continuous)

- Adopt by Parliament wage legislation consistent with the 2010 fiscal policy objectives (Federation) (end March 2010)

- Reform privileged pensions by entity governments (Federation, RS) (end March 2010)

- Prepare a strategy for pension reform by entity governments (Federation, RS) (end March 2010) 


\section{Credible fiscal measures are critical to restore fiscal sustainability. Staff}

acknowledges the authorities' efforts to keep expenditure under control, and recognizes that the program's 2009 fiscal deficit objective was exceeded owing to revenue shortfalls. With revenue performance still weak and strong expenditure pressures ahead of the October 2010 elections, the authorities are to be commended for their commitment to fiscal restraint. To this end, the revised 2010 general government deficit objective strikes an appropriate balance between fiscal policy's response to the cycle and medium-term consolidation objectives. The revised fiscal program focuses on measures that would secure a permanent reduction in recurrent government spending, and strengthens structural fiscal reform commitments.

\section{There is a pressing need to protect spending on public investment and}

vulnerable social groups. The program's focus on lasting reforms to reduce recurrent spending and provide more space for capital expenditure is welcome, and staff emphasizes the need to improve implementation capacity. Social protection is a key element of the authorities' program to reform social benefits. It is thus important to ensure that, through better targeting, these benefits reach the most vulnerable groups. Moreover, staff urges the authorities to strengthen the financial integrity of the public pension systems.

26. It is essential to remain vigilant to any sign of stress in the financial sector. Staff welcomes steps to enhance the monitoring of financial stability, and improve crisis preparedness and management, and urges the authorities to further increase cooperation between the central bank and banking agencies. The commitments by foreign parent banks to maintain their exposure vis-à-vis $\mathrm{BiH}$ and keep their subsidiaries well capitalized should help contain external financing gaps and support market confidence. Staff also welcomes improvements in the capacity to conduct stress tests and urges the authorities to continuously monitor vulnerabilities in the banking system.

27. Political risks to the implementation of the program are rising. With general elections approaching, the political support for the needed adjustment measures and key fiscal structural reforms may fade. To address these concerns, approval of the 2010 budgets and of key fiscal measures are prior actions for Board consideration of the request for completion of this review. In addition, the authorities recognize the need for continued careful program monitoring, and they are committed to adjust policies as circumstances change.

28. Full implementation of the authorities' program offers the best chance for BiH to emerge from the economic crisis ready to resume stronger growth and make faster progress in EU-convergence. In light of performance to date and the policy intentions expressed by the authorities, staff support their request for completion of the first review under the Stand-By Arrangement. 
Figure 1. Bosnia and Herzegovina: Inflation Developments, 2005-09
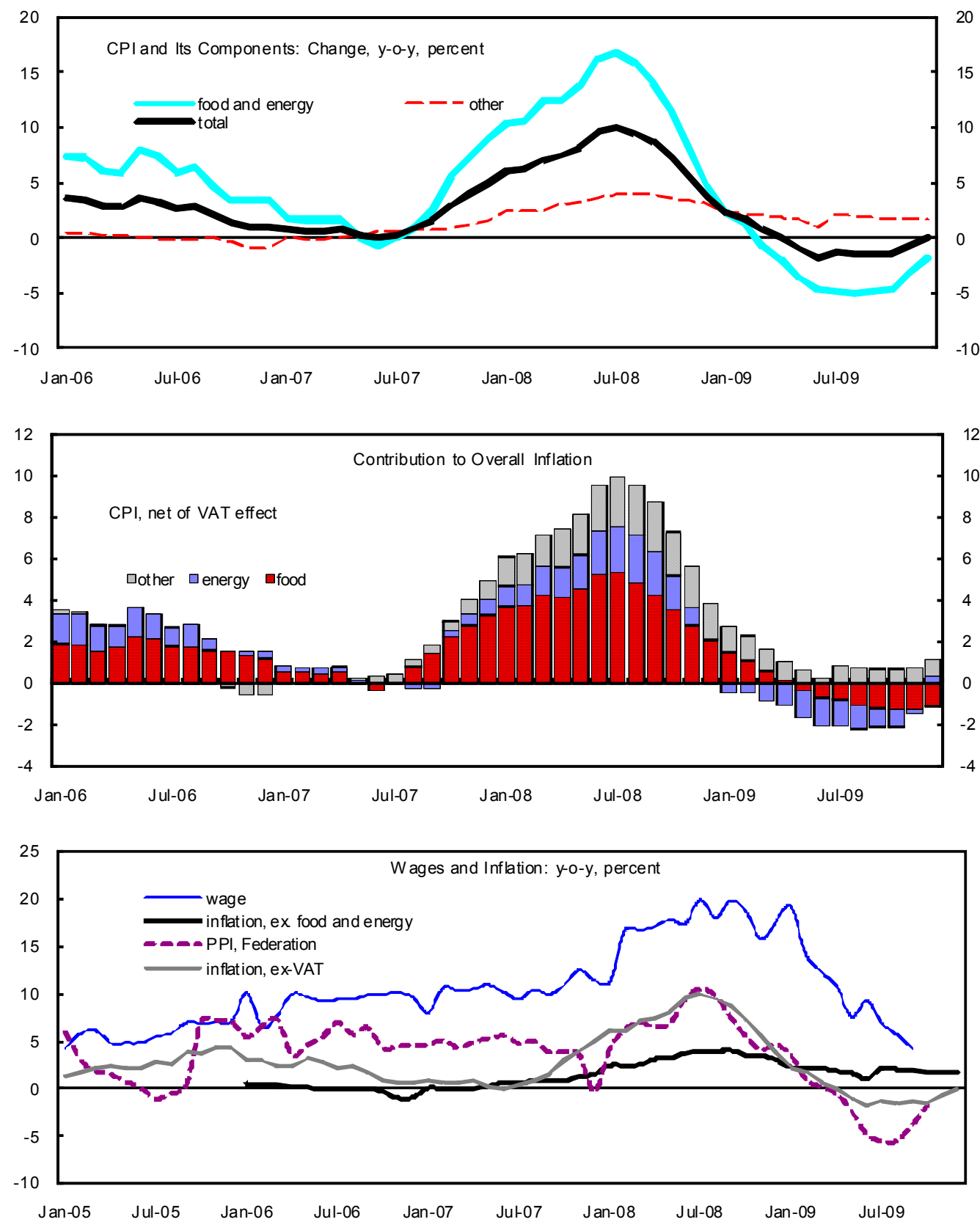

Sources: BiH authorities; and IMF staff calculations. 
Figure 2. Bosnia and Herzegovina: External Trade, 2004-09
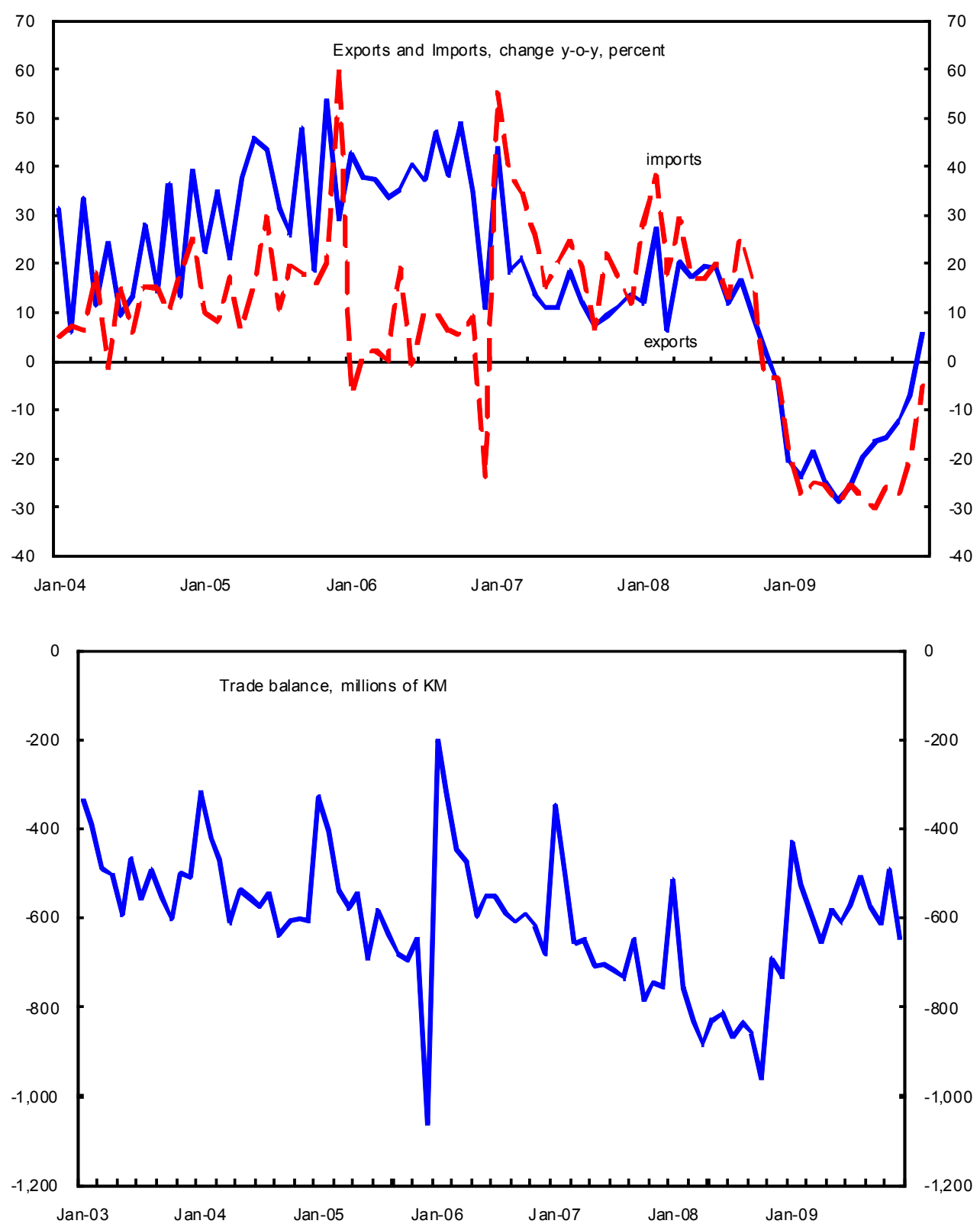

Sources: $\mathrm{CBBH}$; and IMF staff calculations. 
Figure 3. Bosnia and Herzegovina: Central Bank's Foreign Assets and Commercial Bank Reserves, 2008-09
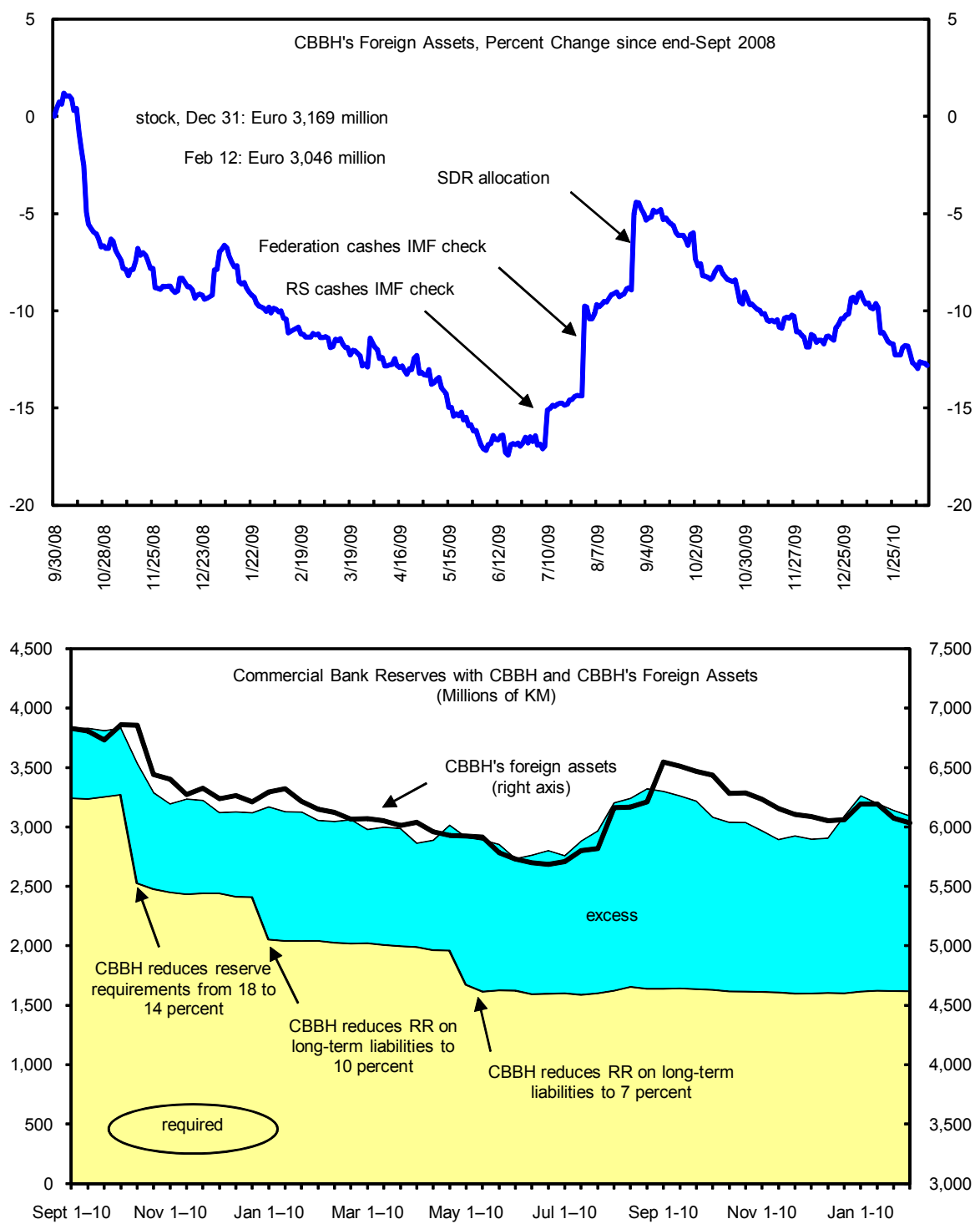

Sources: CBBH; and IMF staff calculations. 
Table 1. Bosnia and Herzegovina: Selected Economic Indicators, 2008-15

\begin{tabular}{|c|c|c|c|c|c|c|c|c|c|c|}
\hline & \multirow[t]{2}{*}{2008} & \multicolumn{2}{|c|}{2009} & \multicolumn{2}{|c|}{2010} & \multirow[t]{2}{*}{2011} & \multirow[t]{2}{*}{2012} & \multirow{2}{*}{$\frac{2013}{\text { Proj. }}$} & \multirow[t]{2}{*}{2014} & \multirow[t]{2}{*}{2015} \\
\hline & & $\begin{array}{c}\text { EBS/09/94 } \\
\text { Prog. }\end{array}$ & Proj. & $\begin{array}{c}\text { EBS/09/94 } \\
\text { Prog. }\end{array}$ & Prog. & & & & & \\
\hline Nominal GDP (KM million) & 24,717 & 24,298 & 24,121 & 25,036 & 24,775 & 26,411 & 28,641 & 30,904 & 33,231 & 35,734 \\
\hline Gross national saving (in percent of GDP) & 9.9 & 10.6 & 11.6 & 13.4 & 14.0 & 15.9 & 15.9 & 16.6 & 17.2 & 17.1 \\
\hline \multirow[t]{2}{*}{ Gross investment (in percent of GDP) } & 24.8 & 20.2 & 19.1 & 23.1 & 21.3 & 22.9 & 22.9 & 22.9 & 23.0 & 22.8 \\
\hline & \multicolumn{10}{|c|}{ (Percent change) } \\
\hline Real GDP & 5.4 & -3.0 & -3.4 & 0.5 & 0.5 & 4.0 & 5.8 & 5.3 & 4.5 & 4.5 \\
\hline $\mathrm{CPI}$ (period average) & 7.4 & 1.6 & -0.4 & 2.3 & 1.6 & 1.9 & 2.1 & 2.3 & 2.5 & 2.5 \\
\hline \multicolumn{11}{|l|}{ Money and credit (end of period) } \\
\hline Broad money & 4.3 & 0.6 & 1.7 & 3.9 & 0.3 & 6.6 & 8.4 & 7.9 & 7.5 & 7.5 \\
\hline Credit to the private sector & 20.8 & 0.0 & -3.8 & 4.0 & -2.7 & 7.3 & 9.3 & 9.1 & 7.9 & 7.9 \\
\hline & \multicolumn{10}{|c|}{ (In percent of GDP) } \\
\hline \multicolumn{11}{|l|}{ General government budget } \\
\hline Revenue & 45.5 & 45.0 & 44.1 & 45.9 & 44.3 & 44.3 & 44.7 & 44.8 & 44.9 & 44.9 \\
\hline Of which: grants & 2.2 & 2.3 & 1.8 & 3.0 & 1.9 & 1.9 & 1.9 & 1.9 & 1.9 & 1.8 \\
\hline Expenditure (on a commitment basis) & 50.3 & 49.7 & 49.4 & 49.9 & 48.8 & 47.2 & 46.4 & 46.0 & 45.4 & 44.9 \\
\hline Of which: investment expenditure & 6.5 & 7.1 & 6.0 & 7.9 & 6.2 & 6.1 & 5.8 & 5.9 & 5.9 & 5.7 \\
\hline Primary balance & -4.3 & -3.8 & -4.7 & -3.0 & -3.9 & -2.2 & -1.0 & -0.5 & 0.0 & 0.5 \\
\hline Overall balance & -4.8 & -4.7 & -5.3 & -4.0 & -4.5 & -2.9 & -1.7 & -1.1 & -0.5 & 0.0 \\
\hline External public debt & 17.2 & 21.5 & 19.9 & 26.3 & 25.5 & 27.2 & 26.7 & 24.2 & 21.1 & 19.4 \\
\hline Total public debt & 30.8 & 34.7 & 33.4 & 39.8 & 38.1 & 38.5 & 36.9 & 33.1 & 28.8 & 25.7 \\
\hline & \multicolumn{10}{|c|}{ (In millions of euros) } \\
\hline \multicolumn{11}{|l|}{ Balance of payments } \\
\hline Exports of goods and services & 4,648 & 3,843 & 3,831 & 4,108 & 4,144 & 4,478 & 4,779 & 5,144 & 5,484 & 5,781 \\
\hline Imports of goods and services & 8,780 & 7,050 & 6,725 & 7,476 & 7,194 & 7,631 & 8,094 & 8,578 & 9,077 & 9,505 \\
\hline Unrequited transfers, net & 1,844 & 1,771 & 1,662 & 1,903 & 1,724 & 1,781 & 1,862 & 1,968 & 2,101 & 2,139 \\
\hline Current account balance & $-1,879$ & $-1,201$ & -921 & $-1,234$ & -930 & -953 & $-1,018$ & -996 & -981 & $-1,039$ \\
\hline (In percent of GDP) & -14.9 & -9.7 & -7.5 & -9.6 & -7.3 & -7.1 & -7.0 & -6.3 & -5.8 & -5.7 \\
\hline Foreign direct investment & 716.9 & 258 & 300.0 & 500 & 350.0 & 678.0 & 728.0 & 758.0 & 778.0 & 778.0 \\
\hline (In percent of GDP) & 5.7 & 2.1 & 2.4 & 3.9 & 2.8 & 5.0 & 5.0 & 4.8 & 4.6 & 4.3 \\
\hline Gross official reserves & 3,219 & 2,932 & 3,176 & 3,007 & 3,421 & 3,751 & 3,915 & 3,821 & 3,636 & 3,618 \\
\hline (In months of imports) & 5.7 & 4.7 & 5.3 & 4.5 & 5.4 & 5.6 & 5.5 & 5.1 & 4.6 & 4.6 \\
\hline External debt, percent of GDP & 48.9 & 52.4 & 53.0 & 56.7 & 58.3 & 59.5 & 58.0 & 54.8 & 51.0 & 48.7 \\
\hline External debt service & 415 & 433 & 452 & 504 & 542 & 571 & 628 & 802 & 1,005 & 831 \\
\hline (In percent of exports of goods and services) & 8.9 & 11.3 & 11.8 & 12.3 & 13.1 & 12.8 & 13.1 & 15.6 & 18.3 & 14.4 \\
\hline
\end{tabular}

Sources: Bosnian authorities; and IMF staff estimates and projections. 
Table 2. Bosnia and Herzegovina: Balance of Payments, 2008-15

(In millions of euros, unless otherwise indicated)

\begin{tabular}{|c|c|c|c|c|c|c|c|c|c|c|c|c|c|c|}
\hline & \multirow{3}{*}{$\begin{array}{c}2008 \\
\text { Est. }\end{array}$} & \multicolumn{2}{|l|}{2009} & \multicolumn{6}{|c|}{2010} & 2011 & 2012 & 2013 & 2014 & 2015 \\
\hline & & \multirow{2}{*}{$\begin{array}{c}\text { EBS/09/94 } \\
\text { Prog. }\end{array}$} & \multirow{2}{*}{ Proj. } & \multicolumn{4}{|c|}{ Flows by quarter } & \multirow{2}{*}{$\begin{array}{c}\text { EBS/09/94 } \\
\text { Prog. }\end{array}$} & \multirow{2}{*}{ Prog. } & \multicolumn{5}{|c|}{ Proj. } \\
\hline & & & & Jan-Mar & Apr-Jun & Jul-Sep & Oct-Dec & & & & & & & \\
\hline Merchandise trade & $-4,819$ & $-3,912$ & $-3,480$ & -991 & -762 & -985 & -920 & $-4,096$ & $-3,658$ & $-3,800$ & $-3,997$ & $-4,165$ & $-4,374$ & $-4,508$ \\
\hline Exports, f.o.b. & 3,522 & 2,713 & 2,819 & 738 & 777 & 843 & 735 & 2,941 & 3,093 & 3,365 & 3,600 & 3,887 & 4,144 & 4,406 \\
\hline Imports, f.o.b. & $-8,341$ & $-6,625$ & $-6,298$ & $-1,729$ & $-1,539$ & $-1,828$ & $-1,656$ & $-7,037$ & $-6,751$ & $-7,166$ & $-7,597$ & $-8,052$ & $-8,519$ & $-8,914$ \\
\hline Reconstruction & -194 & -321 & -267 & $\ldots$ & $\ldots$ & $\ldots$ & $\ldots$ & -357 & -274 & -291 & -258 & -279 & -303 & -306 \\
\hline Other & $-8,147$ & $-6,304$ & $-6,032$ & $\ldots$ & $\ldots$ & $\ldots$ & $\ldots$ & $-6,680$ & $-6,478$ & $-6,874$ & $-7,339$ & $-7,773$ & $-8,216$ & $-8,608$ \\
\hline Services, net & 687 & 704 & 585 & 135 & 175 & 148 & 150 & 728 & 608 & 648 & 682 & 730 & 781 & 784 \\
\hline Exports & 1,126 & 1,130 & 1,012 & 216 & 279 & 319 & 238 & 1,167 & 1,051 & 1,113 & 1,179 & 1,257 & 1,339 & 1,375 \\
\hline Imports & -439 & -425 & -427 & -79 & -101 & -176 & -86 & -439 & -443 & -465 & -496 & -526 & -558 & -591 \\
\hline Income, net & 409 & 235 & 311 & 124 & 79 & 108 & 86 & 231 & 396 & 419 & 435 & 470 & 511 & 546 \\
\hline Credit & 821 & 535 & 611 & 165 & 169 & 206 & 179 & 535 & 718 & 757 & 798 & 849 & 906 & 964 \\
\hline Debit & -411 & -300 & -300 & -47 & -88 & -97 & -90 & -304 & -322 & -338 & -363 & -379 & -395 & -418 \\
\hline Of which: interest & -99 & -125 & -115 & -22 & -32 & -22 & -33 & -147 & -137 & -145 & -159 & -164 & -168 & -178 \\
\hline Current transfers, net & 1,844 & 1,771 & 1,662 & 375 & 447 & 468 & 433 & 1,903 & 1,724 & 1,781 & 1,862 & 1,968 & 2,101 & 2,139 \\
\hline Receipts & 2,020 & 1,944 & 1,847 & $\ldots$ & $\ldots$ & $\ldots$ & $\ldots$ & 2,085 & 1,919 & 1,982 & 2,069 & 2,182 & 2,320 & 2,370 \\
\hline Public & 169 & 180 & 120 & $\ldots$ & $\ldots$ & $\ldots$ & $\cdots$ & 272 & 146 & 151 & 171 & 193 & 214 & 214 \\
\hline Private & 1,851 & 1,764 & 1,727 & $\ldots$ & $\ldots$ & $\ldots$ & $\ldots$ & 1,813 & 1,773 & 1,831 & 1,898 & 1,989 & 2,106 & 2,156 \\
\hline Payments & -176 & -173 & -185 & $\ldots$ & $\ldots$ & $\ldots$ & $\ldots$ & -182 & -195 & -201 & -207 & -213 & -220 & -231 \\
\hline Current account balance & $-1,879$ & $-1,201$ & -921 & -357 & -61 & -261 & -251 & $-1,234$ & -930 & -953 & $-1,018$ & -996 & -981 & $-1,039$ \\
\hline Capital and Financial Accounts & 1,805 & 481 & 632 & 42 & 64 & 167 & 191 & 747 & 463 & 959 & 991 & 903 & 796 & 1,020 \\
\hline Capital account & 198 & 218 & 191 & 45 & 52 & 47 & 50 & 230 & 195 & 210 & 215 & 221 & 226 & 232 \\
\hline Capital transfers & 198 & 218 & 191 & 45 & 52 & 47 & 50 & 230 & 195 & 210 & 215 & 221 & 226 & 232 \\
\hline Official transfers & 91 & 106 & 92 & 23 & 26 & 21 & 23 & 112 & 93 & 105 & 107 & 109 & 111 & 114 \\
\hline Private transfers & 107 & 112 & 99 & 22 & 26 & 26 & 28 & 118 & 102 & 105 & 108 & 111 & 115 & 118 \\
\hline Financial account & 1,607 & 263 & 441 & -3 & 12 & 120 & 141 & 517 & 269 & 749 & 776 & 682 & 570 & 789 \\
\hline Direct investment & 717 & 258 & 300 & 51 & 69 & 115 & 115 & 500 & 350 & 678 & 728 & 758 & 778 & 778 \\
\hline Outward & -9 & 0 & 0 & 0 & 0 & 0 & 0 & 0 & 0 & 0 & 0 & 0 & 0 & 0 \\
\hline Inward & 726 & 258 & 300 & 51 & 69 & 115 & 115 & 500 & 350 & 678 & 728 & 758 & 778 & 778 \\
\hline Portfolio investment & -6 & 0 & 0 & 0 & 0 & 0 & 0 & 0 & 0 & 0 & 0 & 0 & 0 & 0 \\
\hline Other investment & 896 & 5 & 141 & -54 & -57 & 4 & 26 & 17 & -81 & 71 & 48 & -76 & -208 & 11 \\
\hline Assets (increase, - ) & -221 & 103 & -113 & -52 & -45 & 1 & 24 & 59 & -73 & -119 & -124 & -130 & -122 & -129 \\
\hline Commercial banks & 230 & 82 & 60 & -38 & -29 & -4 & 48 & 50 & -23 & -104 & -106 & -110 & -102 & -109 \\
\hline Other & -451 & 21 & -173 & -14 & -17 & 5 & -24 & 9 & -50 & -15 & -18 & -20 & -20 & -20 \\
\hline Liabilities & 1,117 & -98 & 255 & -2 & -12 & 3 & 2 & -42 & -8 & 190 & 171 & 54 & -85 & 139 \\
\hline Trade credits & 282 & -5 & 178 & 42 & 49 & 50 & 45 & 70 & 187 & 205 & 226 & 248 & 273 & 300 \\
\hline Commercial banks & 732 & 0 & -287 & 7 & 7 & 7 & 7 & 0 & 29 & 148 & 187 & 198 & 210 & 223 \\
\hline Amortization & -279 & -308 & -337 & -97 & -114 & -99 & -96 & -357 & -405 & -427 & -469 & -639 & -837 & -653 \\
\hline Drawing of loans & 382 & 215 & 539 & 45 & 45 & 45 & 45 & 245 & 181 & 263 & 228 & 246 & 268 & 269 \\
\hline Project & 103 & 215 & 175 & 45 & 45 & 45 & 45 & 245 & 181 & 186 & 151 & 170 & 192 & 192 \\
\hline Program & 0 & 0 & 203 & 0 & 0 & 0 & 0 & 0 & 0 & 77 & 77 & 77 & 77 & 77 \\
\hline Other government liabilities & 0 & 0 & 161 & 0 & 0 & 0 & 0 & 0 & 0 & 0 & 0 & 0 & 0 & 0 \\
\hline Reserve assets (increase, - ) & 206 & 287 & 45 & 100 & -101 & -56 & -188 & -75 & -245 & -329 & -164 & 93 & 185 & 19 \\
\hline Net Errors and Omissions & -132 & 0 & 0 & & & & & 0 & 0 & 0 & 0 & 0 & 0 & 0 \\
\hline External financing gap & $\ldots$ & 433 & 0 & 215 & 98 & 151 & 248 & 563 & 712 & 323 & 191 & 0 & 0 & 0 \\
\hline \multicolumn{15}{|l|}{ Memorandum items: } \\
\hline Current account balance (percent of GDP) & -14.9 & -9.7 & -7.5 & $\ldots$ & $\ldots$ & $\ldots$ & $\ldots$ & -9.6 & -7.3 & -7.1 & -7.0 & -6.3 & -5.8 & -5.7 \\
\hline Trade balance (percent of GDP) & -38.1 & -31.5 & -28.2 & $\cdots$ & $\ldots$ & $\ldots$ & $\ldots$ & -32.0 & -28.9 & -28.1 & -27.3 & -26.4 & -25.7 & -24.7 \\
\hline Import of goods (change, percent) & 15.3 & -19.7 & -24.5 & $\ldots$ & $\ldots$ & $\ldots$ & $\ldots$ & 6.2 & 7.2 & 6.1 & 6.0 & 6.0 & 5.8 & 4.6 \\
\hline Export of goods (change, percent) & 13.9 & -21.4 & -20.0 & $\ldots$ & $\ldots$ & $\ldots$ & $\ldots$ & 8.4 & 9.7 & 8.8 & 7.0 & 8.0 & 6.6 & 6.3 \\
\hline Transfers (percent of GDP) & 14.6 & 14.3 & 13.5 & $\ldots$ & $\ldots$ & $\ldots$ & $\ldots$ & 14.9 & 13.6 & 13.2 & 12.7 & 12.5 & 12.4 & 11.7 \\
\hline Net foreign direct investment (percent of GDP) & 5.7 & 2.1 & 2.4 & $\ldots$ & $\ldots$ & $\ldots$ & $\ldots$ & 3.9 & 2.8 & 5.0 & 5.0 & 4.8 & 4.6 & 4.3 \\
\hline External debt/GDP (percent) & 48.9 & 52.4 & 53.0 & $\ldots$ & $\ldots$ & $\ldots$ & $\ldots$ & 56.7 & 58.3 & 59.5 & 58.0 & 54.8 & 51.0 & 48.7 \\
\hline Private & 31.8 & 30.8 & 33.0 & $\ldots$ & $\ldots$ & $\ldots$ & $\ldots$ & 30.4 & 32.8 & 32.2 & 31.3 & 30.6 & 29.9 & 29.3 \\
\hline Public & 17.2 & 21.5 & 19.9 & $\ldots$ & $\ldots$ & $\ldots$ & $\ldots$ & 26.3 & 25.5 & 27.2 & 26.7 & 24.2 & 21.1 & 19.4 \\
\hline External public debt service/exports of G\&S (\%) & 8.9 & 11.3 & 11.8 & $\ldots$ & $\ldots$ & $\ldots$ & $\ldots$ & 12.3 & 13.1 & 12.8 & 13.1 & 15.6 & 18.3 & 14.4 \\
\hline Gross official reserves & 3,219 & 2,932 & 3,176 & $\ldots$ & $\ldots$ & $\ldots$ & $\ldots$ & 3,007 & 3,421 & 3,751 & 3,915 & 3,821 & 3,636 & 3,618 \\
\hline (Months of imports of goods and services) & 5.7 & 4.7 & 5.3 & & & 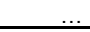 & $\ldots$ & 4.5 & 5.4 & 5.6 & 5.5 & 5.1 & 4.6 & 4.6 \\
\hline
\end{tabular}

Sources: BiH authorities; and IMF staff estimates and projections. 
Table 3. Bosnia and Herzegovina: Selected Vulnerability Indicators, 2004-09

\begin{tabular}{|c|c|c|c|c|c|c|c|}
\hline & 2004 & 2005 & 2006 & 2007 & $\begin{array}{r}2008 \\
\text { Est. }\end{array}$ & $\begin{array}{c}2009 \\
\text { Latest }\end{array}$ & \\
\hline \multicolumn{8}{|l|}{ External sector } \\
\hline Exports of goods (change, percent, in euros) & 28.7 & 22.8 & 30.5 & 15.0 & 13.9 & -20.0 & Dec-C \\
\hline Imports of goods (change, percent, in euros) & 7.6 & 12.5 & 1.2 & 18.7 & 15.3 & -24.5 & Dec-C \\
\hline Terms of trade (change, percent) & 3.8 & 6.2 & 8.4 & 5.5 & -1.5 & -6.4 & Sep-C \\
\hline Current account balance (percent of GDP) & -16.3 & -18.0 & -8.4 & -12.6 & -14.9 & -6.8 & Sep-C \\
\hline Capital and financial account (percent of GDP) & 16.8 & 19.7 & 12.7 & 16.6 & 14.3 & 6.3 & Sep-C \\
\hline Net FDI inflows (percent of GDP) & 7.0 & 5.5 & 5.8 & 13.2 & 5.7 & 2.5 & Sep-C \\
\hline Gross international reserves (end of period, millions of euros) & 1,768 & 2,145 & 2,761 & 3,425 & 3,219 & 3,176 & Dec-C \\
\hline In months of prospective imports of goods and services & 3.3 & 4.0 & 4.3 & 4.7 & 5.7 & 5.3 & Dec-C \\
\hline In percent of short-term debt at remaining maturity & 448.7 & 469.2 & 743.4 & 370.7 & 392.4 & 365.1 & Dec-C \\
\hline In percent of reserve money & 106.7 & 105.7 & 106.9 & 107.5 & 110.4 & 110.0 & Dec-C \\
\hline Total gross external debt (percent of GDP) & 48.7 & 52.7 & 47.2 & 48.2 & 48.9 & 52.4 & Sep-C \\
\hline Of which short-term external debt (remaining maturity, percent of GDP) & 5.6 & 7.2 & 5.5 & 7.8 & 6.4 & 7.0 & Sep-C \\
\hline Of which extermal public debt (percent of GDP) & 25.5 & 25.6 & 21.2 & 18.2 & 17.2 & 19.5 & Sep-C \\
\hline REER (annual average percentage change; depreciation =-) & -1.6 & 0.8 & 2.3 & -1.8 & 2.2 & $\ldots$ & 200 \\
\hline Exchange rate (per U.S. dollar, period average) & 1.58 & 1.57 & 1.56 & 1.43 & 1.34 & 1.4 & 200 \\
\hline \multicolumn{8}{|l|}{ Financial market indicators } \\
\hline \multicolumn{8}{|l|}{ Stock market indices, end of period } \\
\hline Banja Luka Stock Exchange ${ }^{1}$ & 1,150 & 1,367 & 2,885 & 2,564 & 1,028 & 1021 & Oct-C \\
\hline Sarajevo Stock Exchange ${ }^{2}$ & $\ldots$ & 1,612 & 2,856 & 3,685 & 1,234 & 1,129 & Oct-C \\
\hline \multicolumn{8}{|l|}{ Sovereign ratings } \\
\hline Moody's foreign currency sovereign rating & B3/positive & Dositive & B2/stable & B2/stable & B2/stable & B2/stable & Dec-C \\
\hline S\&P's sovereign rating & $\ldots$ & $\ldots$ & $\ldots$ & $\ldots$ & $\ldots$ & $\mathrm{B}+/$ stable & Dec-C \\
\hline
\end{tabular}

Sources: Bosnian authorities; and IMF staff estimates and projections.

${ }^{1}$ Banja Luka Stock Exchange's BIRS index.

${ }^{2}$ Sarajevo Stock Exchange's SASX-10 index 
Table 4. Bosnia and Herzegovina: General Government, 2008-15

(In percent of GDP)

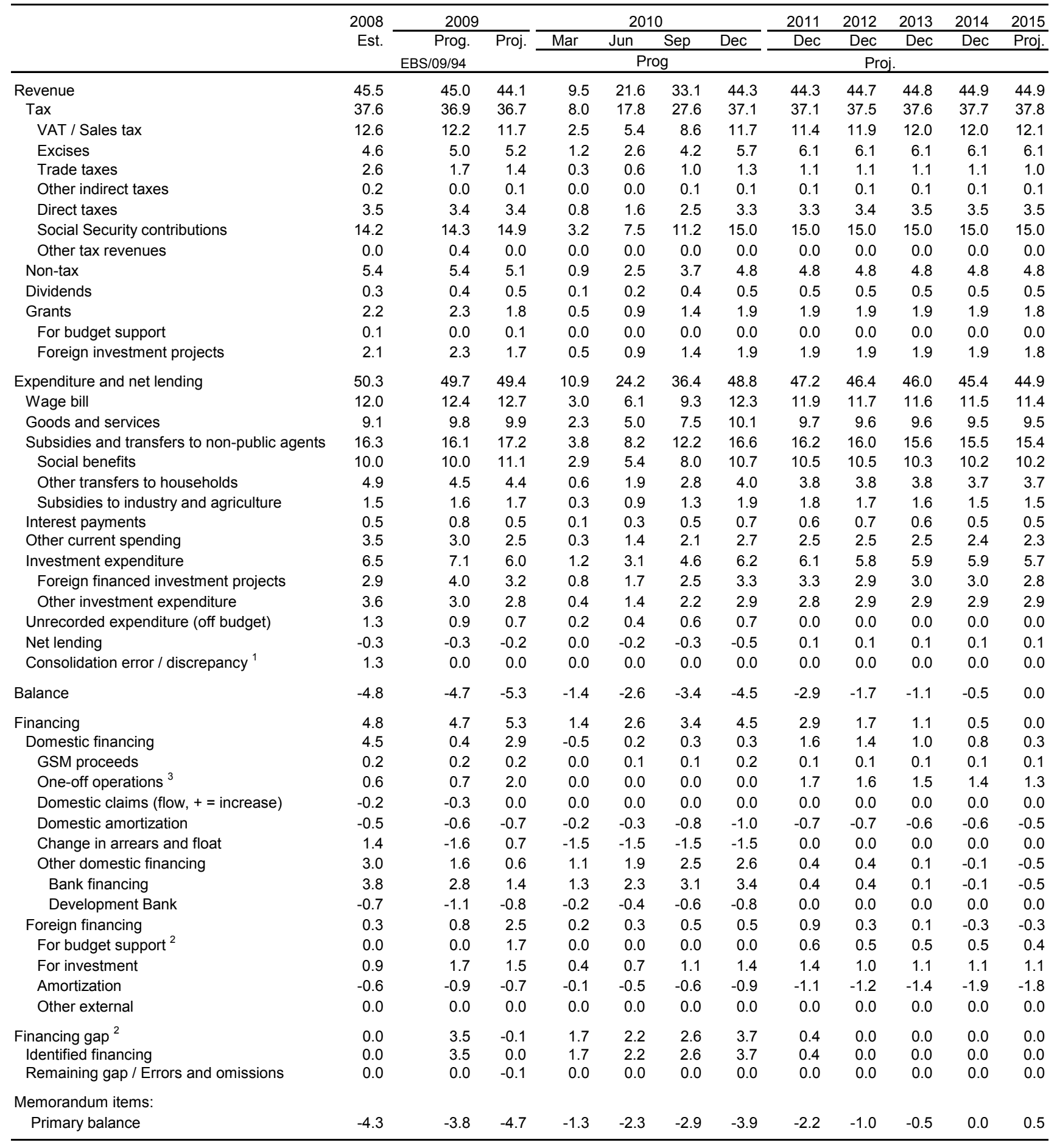

Sources: Ministries of Finance; and IMF staff estimates.

${ }^{1}$ The 2008 amount represents a discrepancy between above- and below-the-line totals.

2 Disbursements of budget support loans and grants from multilateral creditors are recorded under "Foreign financing for budget support" and "Grants for budget support", respectively, in the year they are drawn, and under "Identified financing of financing gap" in projections.

Projected issuance of international bonds in 2011-14 for general budget financing are recorded under "Foreign financing for budget support."

${ }^{3}$ Includes proceeds from privatization, succession funds, and the use of the 2009 SDR allocations. 
Table 5. Bosnia and Herzegovina: General Government, 2008-15

(Millions of $\mathrm{KM}$ )

\begin{tabular}{|c|c|c|c|c|c|c|c|c|c|c|c|c|}
\hline \multirow[t]{3}{*}{. } & \multirow{3}{*}{$\begin{array}{r}2008 \\
\text { Est. }\end{array}$} & \multicolumn{2}{|l|}{2009} & \multicolumn{4}{|c|}{2010} & \multirow{2}{*}{$\begin{array}{r}2011 \\
\text { Dec } \\
\end{array}$} & \multirow{2}{*}{$\begin{array}{r}2012 \\
\mathrm{Dec} \\
\end{array}$} & \multirow{2}{*}{$\begin{array}{r}2013 \\
\mathrm{Dec} \\
\end{array}$} & \multirow{2}{*}{$\begin{array}{r}2014 \\
\text { Dec } \\
\end{array}$} & \multirow{2}{*}{$\begin{array}{r}2015 \\
\mathrm{Dec} \\
\end{array}$} \\
\hline & & Prog & Proj. & Mar & Jun & Sep & $\overline{D e c}$ & & & & & \\
\hline & & \multicolumn{2}{|l|}{ EBS/09/94 } & \multicolumn{4}{|c|}{ Prog } & \multicolumn{5}{|c|}{ Proj } \\
\hline Revenue & 11,245 & 10,942 & 10,643 & 2,349 & 5,340 & 8,189 & 10,973 & 11,694 & 12,803 & 13,857 & 14,928 & 16,037 \\
\hline Tax revenue & 9,296 & 8,961 & 8,856 & 1,976 & 4,420 & 6,839 & 9,193 & 9,787 & 10,745 & 11,631 & 12,535 & 13,507 \\
\hline VAT / Sales tax & 3,119 & 2,956 & 2,828 & 609 & 1,341 & 2,142 & 2,902 & 3,020 & 3,397 & 3,695 & 3,996 & 4,324 \\
\hline Excises & 1,127 & 1,219 & 1,247 & 297 & 653 & 1,043 & 1,413 & 1,601 & 1,736 & 1,873 & 2,014 & 2,166 \\
\hline Trade taxes & 646 & 422 & 341 & 69 & 151 & 242 & 328 & 297 & 315 & 334 & 353 & 370 \\
\hline Other indirect taxes & 40 & 0 & 21 & 5 & 10 & 15 & 20 & 22 & 22 & 24 & 25 & 27 \\
\hline Direct taxes & 864 & 814 & 827 & 203 & 406 & 609 & 812 & 884 & 976 & 1,068 & 1,158 & 1,257 \\
\hline Social Security contributions & 3,500 & 3,464 & 3,590 & 792 & 1,857 & 2,786 & 3,715 & 3,960 & 4,295 & 4,635 & 4,984 & 5,359 \\
\hline Other tax revenues & 0 & 86 & 2 & 1 & 1 & 2 & 2 & 3 & 3 & 3 & 3 & 4 \\
\hline Non- tax revenue & 1,331 & 1,310 & 1,231 & 232 & 624 & 907 & 1,189 & 1,279 & 1,376 & 1,484 & 1,596 & 1,716 \\
\hline Dividends & 83 & 102 & 117 & 24 & 60 & 90 & 120 & 128 & 139 & 150 & 161 & 173 \\
\hline Grants & 535 & 569 & 439 & 118 & 235 & 353 & 471 & 501 & 544 & 591 & 636 & 641 \\
\hline Budget support & 28 & 10 & 25 & 1 & 2 & 3 & 4 & 0 & 0 & 0 & 0 & 0 \\
\hline Foreign investment projects & 508 & 559 & 414 & 117 & 233 & 350 & 467 & 501 & 544 & 591 & 636 & 641 \\
\hline Expenditure and net lending & 12,432 & 12,083 & 11,912 & 2,700 & 5,992 & 9,022 & 12,100 & 12,454 & 13,303 & 14,207 & 15,101 & 16,055 \\
\hline Wage bill & 2,958 & 3,001 & 3,069 & 734 & 1,514 & 2,305 & 3,058 & 3,140 & 3,344 & 3,592 & 3,823 & 4,071 \\
\hline Goods and services & 2,260 & 2,378 & 2,387 & 564 & 1,243 & 1,863 & 2,491 & 2,566 & 2,755 & 2,959 & 3,149 & 3,386 \\
\hline Subsidies and transfers to non-public agents & 4,038 & 3,907 & 4,157 & 942 & 2,020 & 3,030 & 4,109 & 4,275 & 4,588 & 4,836 & 5,149 & 5,492 \\
\hline Social benefits & 2,463 & 2,431 & 2,687 & 725 & 1,328 & 1,992 & 2,656 & 2,780 & 3,015 & 3,188 & 3,405 & 3,636 \\
\hline Other transfers to households & 1,199 & 1,096 & 1,069 & 142 & 469 & 704 & 979 & 1,017 & 1,093 & 1,167 & 1,241 & 1,327 \\
\hline dustry and agriculture & 376 & 380 & 400 & 75 & 223 & 334 & 475 & 478 & 481 & 481 & 504 & 528 \\
\hline Interest & 130 & 206 & 130 & 27 & 75 & 113 & 162 & 169 & 202 & 195 & 175 & 187 \\
\hline Other current spending & 863 & 733 & 614 & 83 & 341 & 511 & 678 & 670 & 727 & 784 & 808 & 833 \\
\hline Investment expenditure & 1,604 & 1,717 & 1,437 & 304 & 767 & 1,150 & 1,533 & 1,608 & 1,659 & 1,810 & 1,964 & 2,052 \\
\hline Foreign financed investment projects & 709 & 979 & 772 & 205 & 410 & 615 & 821 & 865 & 839 & 923 & 1,011 & 1,017 \\
\hline Other investment expenditure & 895 & 738 & 664 & 99 & 356 & 535 & 712 & 743 & 820 & 887 & 952 & 1,035 \\
\hline Unrecorded expenditure & 315 & 218 & 178 & 38 & 91 & 137 & 182 & 0 & 0 & 0 & 0 & 0 \\
\hline Net lending & -62 & -78 & -60 & 9 & -57 & -86 & -113 & 26 & 28 & 30 & 33 & 35 \\
\hline Consolidation error / discrepancy ${ }^{1}$ & 326 & 0 & 0 & 0 & 0 & 0 & 0 & 0 & 0 & 0 & 0 & 0 \\
\hline Balance on a commitment basis & $-1,187$ & $-1,140$ & $-1,270$ & -351 & -653 & -833 & $-1,127$ & -760 & -500 & -350 & -173 & -17 \\
\hline Financing on a commitment basis & 1,187 & 1,140 & 1,270 & 351 & 653 & 833 & 1,127 & 760 & 500 & 350 & 173 & 17 \\
\hline Domestic financing & 1,118 & 97 & 691 & -125 & 51 & 68 & 78 & 409 & 407 & 311 & 271 & 121 \\
\hline GSM proceeds & 48 & 42 & 40 & 12 & 25 & 37 & 50 & 28 & 28 & 28 & 28 & 28 \\
\hline One-off operations ${ }^{3}$ & 139 & 175 & 488 & 0 & 0 & 0 & 0 & 450 & 450 & 450 & 450 & 450 \\
\hline Domestic claims (flow, $+=$ increase) & -40 & -47 & -5 & 0 & 0 & 0 & 0 & 0 & 0 & 0 & 0 & 0 \\
\hline Domestic amortization & -117 & -91 & -167 & -52 & -85 & -209 & -248 & -186 & -195 & -195 & -190 & -167 \\
\hline Change in arrears and float & 335 & -384 & 180 & -368 & -368 & -368 & -368 & 0 & 0 & 0 & 0 & 0 \\
\hline Other domestic financing & 752 & 401 & 155 & 283 & 480 & 609 & 645 & 118 & 124 & 28 & -17 & -189 \\
\hline Bank financing & 932 & 676 & 344 & 333 & 580 & 759 & 845 & 118 & 124 & 28 & -17 & -189 \\
\hline Development Bank (RS) & -180 & $\ldots$ & -189 & -50 & -100 & -150 & -200 & 0 & 0 & 0 & 0 & 0 \\
\hline Foreign fir & 69 & 198 & 596 & 55 & 63 & 117 & 120 & 237 & 93 & 39 & -98 & -104 \\
\hline For budget support ${ }^{2}$ & 0 & 0 & 398 & 0 & 0 & 0 & 0 & 150 & 150 & 150 & 150 & 150 \\
\hline For investment & 214 & 420 & 358 & 88 & 177 & 265 & 354 & 364 & 295 & 332 & 375 & 376 \\
\hline Amortization & -145 & -223 & -161 & -33 & -114 & -148 & -234 & -277 & -352 & -442 & -623 & -630 \\
\hline Change in arrears & 0 & 0 & 0 & 0 & 0 & 0 & 0 & 0 & 0 & 0 & 0 & 0 \\
\hline Financing gap ${ }^{2}$ & 0 & 846 & -17 & 421 & 539 & 648 & 929 & 113 & 0 & 0 & 0 & 0 \\
\hline Identified financing & 0 & 839 & 0 & 421 & 539 & 648 & 929 & 113 & 0 & 0 & 0 & 0 \\
\hline Remaining gap / Errors and omissions & 0 & 7 & -17 & 0 & 0 & 0 & 0 & 0 & 0 & 0 & 0 & 0 \\
\hline
\end{tabular}

Sources: Ministries of Finance; and IMF staff estimates.

${ }^{1}$ The 2008 amount represents a discrepancy between above- and below-the-line totals.

${ }^{2}$ Disbursements of budget support loans and grants from multilateral creditors are recorded under "Foreign financing for budget support" and "Grants for budget support", respectively, in the year they are drawn, and under "Identified financing of financing gap" in projections.

Projected issuance of international bonds in 2011-14 for general budget financing are recorded under "Foreign financing for budget support."

${ }^{3}$ Includes proceeds from privatization, succession funds, and the use of the 2009 SDR allocations. 
Table 5a. Bosnia and Herzegovina: State Government, 2008-15

(Millions of $\mathrm{KM}$ )

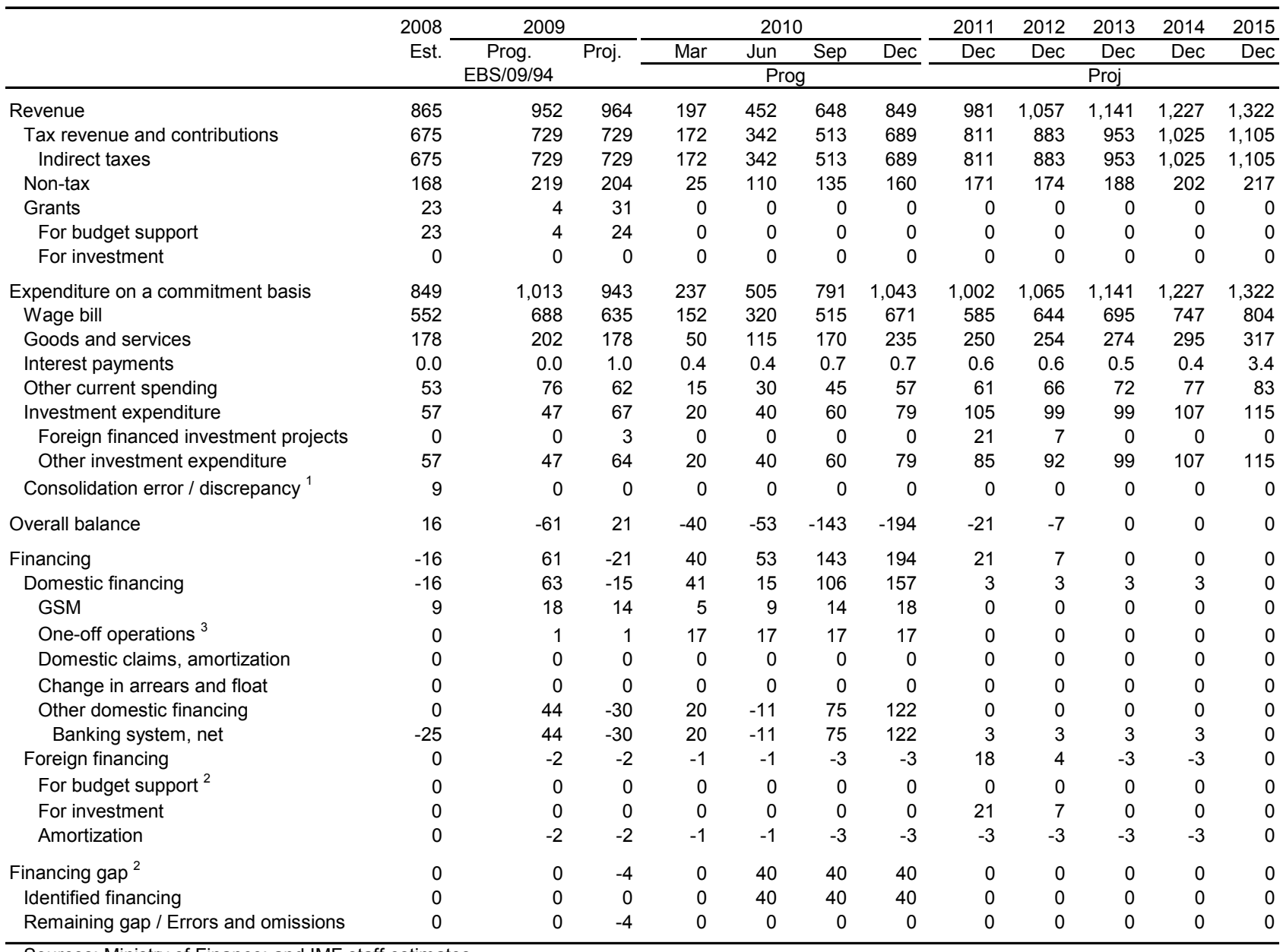

Sources: Ministry of Finance; and IMF staff estimates.

1 The 2008 amount represents a discrepancy between above- and below-the-line totals.

${ }^{2}$ Disbursements of budget support loans and grants from multilateral creditors are recorded under "Foreign financing for budget support" and "Grants for budget support", respectively, in the year they are drawn, and under "Identified financing of financing gap" in projections.

Projected issuance of international bonds in 2011-14 for general budget financing are recorded under "Foreign financing for budget support."

${ }^{3}$ Includes proceeds from privatization, succession funds, and the use of the 2009 SDR allocations. 
Table 5b. Bosnia and Herzegovina: Federation BiH Consolidated General Government, 2008-15 (Millions of KM)

\begin{tabular}{|c|c|c|c|c|c|c|c|c|c|c|c|c|}
\hline & \multirow{3}{*}{$\begin{array}{c}2008 \\
\text { Est. }\end{array}$} & \multicolumn{2}{|l|}{2009} & \multicolumn{4}{|c|}{2010} & \multirow{3}{*}{$\begin{array}{r}2011 \\
\mathrm{Dec} \\
\end{array}$} & \multirow{3}{*}{$\begin{array}{r}2012 \\
\text { Dec } \\
\end{array}$} & \multirow{3}{*}{$\begin{array}{r}2013 \\
\text { Dec } \\
\text { Proj }\end{array}$} & \multirow{3}{*}{$\begin{array}{r}2014 \\
\text { Dec } \\
\end{array}$} & \multirow{3}{*}{$\begin{array}{r}2015 \\
\mathrm{Dec} \\
\end{array}$} \\
\hline & & \multirow{2}{*}{$\begin{array}{c}\text { Prog. } \\
\text { EBS/09/94 }\end{array}$} & \multirow[t]{2}{*}{ Proj. } & Mar & Jun & Sep & $\mathrm{Dec}$ & & & & & \\
\hline & & & & \multicolumn{4}{|c|}{ Prog } & & & & & \\
\hline Revenue & 6,788 & 6,675 & 6,344 & 1,396 & 3,227 & 4,975 & 6,678 & 7,062 & 7,747 & 8,392 & 9,045 & 9,718 \\
\hline Tax revenue and contributions & 5,739 & 5,510 & 5,350 & 1,180 & 2,694 & 4,177 & 5,613 & 5,925 & 6,513 & 7,058 & 7,610 & 8,204 \\
\hline Indirect taxes & 2,719 & 2,506 & 2,407 & 522 & 1,171 & 1,891 & 2,566 & 2,667 & 2,962 & 3,211 & 3,464 & 3,734 \\
\hline Direct taxes & 510 & 518 & 493 & 118 & 235 & 353 & 470 & 511 & 572 & 632 & 689 & 753 \\
\hline Social Security contributions & 2,510 & 2,485 & 2,451 & 541 & 1,288 & 1,933 & 2,577 & 2,747 & 2,979 & 3,214 & 3,457 & 3,717 \\
\hline Non-tax & 624 & 689 & 599 & 114 & 317 & 475 & 634 & 675 & 732 & 790 & 850 & 914 \\
\hline Grants & 341 & 374 & 277 & 78 & 156 & 233 & 311 & 334 & 363 & 394 & 424 & 427 \\
\hline For budget support & 3 & 1 & 1 & 0 & 0 & 0 & 0 & 0 & 0 & 0 & 0 & 0 \\
\hline For investment & 339 & 373 & 276 & 78 & 156 & 233 & 311 & 334 & 363 & 394 & 424 & 427 \\
\hline Dividends & 83 & 102 & 117 & 24 & 60 & 90 & 120 & 128 & 139 & 150 & 161 & 173 \\
\hline Expenditure on a commitment basis & 7,515 & 7,220 & 6,895 & 1,531 & 3,519 & 5,277 & 7,117 & 7,571 & 8,142 & 8,724 & 9,264 & 9,875 \\
\hline Wage bill & 1,556 & 1,406 & 1,528 & 353 & 738 & 1,108 & 1,477 & 1,627 & 1,749 & 1,871 & 1,996 & 2,131 \\
\hline of which: severance package & 0 & 0 & -26 & 0 & 0 & 0 & 0 & 0 & 0 & 0 & 0 & 0 \\
\hline Goods and services & 1,393 & 1,395 & 1,456 & 334 & 751 & 1,127 & 1,502 & 1,564 & 1,692 & 1,825 & 1,935 & 2,080 \\
\hline Subsidies and transfers to non-public agents & 2,821 & 2,709 & 2,742 & 601 & 1,315 & 1,973 & 2,699 & 2,844 & 3,082 & 3,255 & 3,486 & 3,739 \\
\hline Social benefits & 1,706 & 1,667 & 1,699 & 478 & 855 & 1,282 & 1,709 & 1,822 & 1,976 & 2,089 & 2,247 & 2,416 \\
\hline Other transfers to households & 909 & 826 & 806 & 82 & 346 & 520 & 733 & 755 & 823 & 879 & 935 & 1,000 \\
\hline Subsidies to industry and agriculture & 206 & 216 & 236 & 40 & 114 & 171 & 257 & 268 & 283 & 287 & 304 & 323 \\
\hline Interest payments & 71 & 127 & 73 & 16 & 51 & 75 & 110 & 109 & 125 & 120 & 109 & 113 \\
\hline Other current spending & 552 & 489 & 385 & 41 & 234 & 351 & 469 & 467 & 506 & 546 & 562 & 580 \\
\hline Investment expenditure & 851 & 1,143 & 753 & 171 & 459 & 688 & 918 & 933 & 959 & 1,076 & 1,143 & 1,196 \\
\hline Foreign financed investment projects & 471 & 653 & 486 & 137 & 273 & 410 & 546 & 545 & 537 & 615 & 674 & 678 \\
\hline Other investment expenditure & 380 & 490 & 267 & 35 & 186 & 279 & 371 & 388 & 423 & 461 & 468 & 519 \\
\hline Unrecorded expenditures & 0 & & & & & & & & & & & \\
\hline Net lending & -64 & -49 & -41 & 15 & -29 & -44 & -57 & 26 & 28 & 30 & 33 & 35 \\
\hline Consolidation error / discrepancy ${ }^{1}$ & 278 & 0 & 0 & 0 & 0 & 0 & 0 & 0 & 0 & 0 & 0 & 0 \\
\hline Overall balance & -727 & -545 & -552 & -135 & -293 & -302 & -439 & -509 & -395 & -332 & -219 & -157 \\
\hline Financing & 727 & 545 & 552 & 135 & 293 & 302 & 439 & 509 & 395 & 332 & 219 & 157 \\
\hline Domestic financing & 680 & -199 & 183 & -186 & -88 & -191 & -230 & 414 & 446 & 399 & 373 & 316 \\
\hline GSM & 15 & 0 & 16 & 6 & 11 & 17 & 22 & 22 & 22 & 22 & 22 & 22 \\
\hline One-off operations ${ }^{3}$ & 10 & 124 & 322 & -14 & -14 & -14 & -14 & 450 & 450 & 450 & 450 & 450 \\
\hline Domestic amortization & -14 & -91 & -73 & -6 & -16 & -84 & -97 & -100 & -87 & -82 & -76 & -53 \\
\hline Domestic claims (flow, $+=$ increase) & -40 & 16 & -5 & 0 & 0 & 0 & 0 & 0 & 0 & 0 & 0 & 0 \\
\hline Change in arrears and float & 335 & -356 & 113 & -232 & -232 & -232 & -232 & 0 & 0 & 0 & 0 & 0 \\
\hline Other domestic financing & 374 & 108 & -191 & 61 & 164 & 122 & 91 & 42 & 61 & 9 & -23 & -103 \\
\hline Banking system, net & 374 & 108 & -191 & 61 & 164 & 122 & 91 & 42 & 61 & 9 & -23 & -103 \\
\hline Transfer to the Development Bank & 0 & 0 & 0 & 0 & 0 & 0 & 0 & 0 & 0 & 0 & 0 & 0 \\
\hline Foreign financing & 48 & 139 & 374 & 41 & 48 & 89 & 94 & 27 & -51 & -67 & -154 & -159 \\
\hline Loan disbursement & 144 & 280 & 477 & 59 & 118 & 176 & 235 & 211 & 174 & 221 & 250 & 251 \\
\hline Project & 144 & 280 & 210 & 59 & 118 & 176 & 235 & 211 & 174 & 221 & 250 & 251 \\
\hline Budget support ${ }^{2}$ & 0 & 0 & 267 & 0 & 0 & 0 & 0 & 0 & 0 & 0 & 0 & 0 \\
\hline Amortization & -97 & -141 & -103 & -18 & -69 & -88 & -141 & -185 & -225 & -288 & -404 & -409 \\
\hline Financing gap ${ }^{2}$ & 0 & 605 & -6 & 281 & 332 & 405 & 574 & 68 & 0 & 0 & 0 & 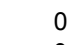 \\
\hline Identified financing & 0 & 598 & 0 & 281 & 332 & 405 & 574 & 68 & 0 & 0 & 0 & 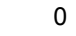 \\
\hline Remaining gap / Errors and omissions & 0 & 7 & -6 & 0 & 0 & 0 & 0 & 0 & 0 & 0 & 0 & 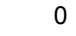 \\
\hline
\end{tabular}

Sources: Ministry of Finance; and IMF staff estimates.

${ }^{1}$ The 2008 amount represents a discrepancy between above- and below-the-line totals.

2 Disbursements of budget support loans and grants from multilateral creditors are recorded under "Foreign financing for budget support" and "Grants for budget support", respectively, in the year they are drawn, and under "Identified financing of financing gap" in projections.

Projected issuance of international bonds in 2011-14 for general budget financing are recorded under "Foreign financing for budget support."

${ }^{3}$ Includes proceeds from privatization, succession funds, and the use of the 2009 SDR allocations. 
Table 5c. Bosnia and Herzegovina: Republika Srpska Consolidated General Government, 2008-15

(Millions of KM)

\begin{tabular}{|c|c|c|c|c|c|c|c|c|c|c|c|c|}
\hline & \multirow{3}{*}{$\begin{array}{l}2008 \\
\text { Est. }\end{array}$} & \multicolumn{2}{|l|}{2009} & \multicolumn{4}{|c|}{2010} & \multirow{2}{*}{$\begin{array}{r}2011 \\
\text { Dec }\end{array}$} & \multirow{2}{*}{$\begin{array}{r}2012 \\
\text { Dec }\end{array}$} & \multirow{2}{*}{$\begin{array}{r}2013 \\
\mathrm{Dec}\end{array}$} & \multirow{2}{*}{$\begin{array}{r}2014 \\
\mathrm{Dec}\end{array}$} & \multirow{2}{*}{$\begin{array}{r}2015 \\
\text { Dec }\end{array}$} \\
\hline & & \multirow{2}{*}{$\begin{array}{c}\text { Prog. } \\
\text { EBS/09/94 } \\
\end{array}$} & \multirow[t]{2}{*}{ Proj. } & Mar & Jun & Sep & $\overline{\mathrm{Dec}}$ & & & & & \\
\hline & & & & \multicolumn{4}{|c|}{ Prog } & & & Proj & & \\
\hline Revenue & 3,374 & 3,109 & 3,189 & 713 & 1,569 & 2,421 & 3,250 & 3,442 & 3,768 & 4,074 & 4,387 & 4,707 \\
\hline Tax & 2,705 & 2,498 & 2,660 & 591 & 1,314 & 2,037 & 2,738 & 2,888 & 3,167 & 3,425 & 3,689 & 3,971 \\
\hline Indirect taxes & 1,386 & 1,247 & 1,202 & 258 & 580 & 937 & 1,271 & 1,316 & 1,462 & 1,585 & 1,710 & 1,843 \\
\hline Direct taxes & 330 & 272 & 319 & 83 & 165 & 247 & 329 & 359 & 389 & 420 & 452 & 486 \\
\hline Social Security contributions & 989 & 979 & 1,140 & 250 & 569 & 854 & 1,138 & 1,213 & 1,316 & 1,420 & 1,527 & 1,642 \\
\hline Non-tax & 497 & 421 & 391 & 82 & 176 & 264 & 352 & 386 & 419 & 452 & 486 & 523 \\
\hline Grants & 171 & 191 & 138 & 40 & 80 & 120 & 160 & 167 & 181 & 197 & 212 & 214 \\
\hline For budget support & 2 & 5 & 0 & 1 & 2 & 3 & 4 & 0 & 0 & 0 & 0 & 0 \\
\hline For investment & 169 & 186 & 138 & 39 & 78 & 117 & 156 & 167 & 181 & 197 & 212 & 214 \\
\hline Expenditure on a commitment basis & 3,872 & 3,655 & 3,914 & 884 & 1,872 & 2,811 & 3,749 & 3,694 & 3,883 & 4,115 & 4,341 & 4,572 \\
\hline Wage bill & 781 & 828 & 839 & 208 & 413 & 620 & 826 & 854 & 872 & 941 & 988 & 1,038 \\
\hline Goods and services & 689 & 737 & 705 & 167 & 352 & 528 & 704 & 697 & 749 & 797 & 851 & 915 \\
\hline Subsidies and transfers to non-public agents & 1,179 & 1,160 & 1,384 & 332 & 687 & 1,030 & 1,373 & 1,392 & 1,464 & 1,535 & 1,614 & 1,700 \\
\hline Social benefits & 758 & 764 & 988 & 247 & 473 & 710 & 946 & 958 & 1,039 & 1,099 & 1,158 & 1,220 \\
\hline Other transfers to households & 263 & 241 & 242 & 53 & 111 & 166 & 221 & 236 & 241 & 257 & 273 & 291 \\
\hline Subsidies to industry and agriculture & 158 & 154 & 154 & 32 & 103 & 154 & 206 & 198 & 184 & 179 & 183 & 188 \\
\hline Interest payments & 59 & 78 & 56 & 10 & 23 & 36 & 50 & 58 & 76 & 74 & 66 & 70 \\
\hline Other current spending & 251 & 153 & 163 & 26 & 74 & 110 & 147 & 136 & 148 & 160 & 161 & 163 \\
\hline Investment expenditure & 649 & 509 & 608 & 109 & 261 & 392 & 523 & 556 & 574 & 608 & 660 & 686 \\
\hline Foreign financed investment projects & 239 & 326 & 286 & 69 & 137 & 206 & 274 & 299 & 295 & 308 & 337 & 339 \\
\hline Other investment expenditure & 411 & 183 & 322 & 41 & 124 & 186 & 248 & 257 & 279 & 301 & 323 & 348 \\
\hline Off-budget & 259 & 218 & 178 & 38 & 91 & 137 & 182 & 0 & 0 & 0 & 0 & 0 \\
\hline Net lending $(+/-)$ & 2 & -30 & -18 & -7 & -28 & -42 & -56 & 0 & 0 & 0 & 0 & 0 \\
\hline Consolidation error / discrepancy ${ }^{1}$ & 2 & 0 & 0 & 0 & 0 & 0 & 0 & 0 & 0 & 0 & 0 & 0 \\
\hline Overall balance & -498 & -546 & -725 & -170 & -303 & -390 & -500 & -253 & -116 & -41 & 46 & 135 \\
\hline Financing & 498 & 546 & 725 & 170 & 303 & 390 & 500 & 253 & 116 & 41 & -46 & -135 \\
\hline Domestic financing & 476 & 244 & 519 & 14 & 121 & 156 & 157 & 15 & -24 & -69 & -105 & -190 \\
\hline GSM & 25 & 8 & 10 & 2 & 5 & 7 & 10 & 6 & 6 & 6 & 6 & 6 \\
\hline One-off operations ${ }^{3}$ & 129 & 50 & 163 & -8 & -8 & -8 & -8 & 0 & 0 & 0 & 0 & 0 \\
\hline Domestic claims, amortization & -103 & -47 & -90 & -46 & -69 & -121 & -147 & -82 & -102 & -107 & -108 & -108 \\
\hline Change in arrears and float & 0 & -27 & 67 & -136 & -136 & -136 & -136 & 0 & 0 & 0 & 0 & 0 \\
\hline Other domestic financing & 425 & 261 & 370 & 201 & 329 & 414 & 438 & 91 & 73 & 33 & -4 & -89 \\
\hline Banking system, net & 605 & 536 & 558 & 251 & 429 & 564 & 638 & 91 & 73 & 33 & -4 & -89 \\
\hline Transfer to the Development Bank & -180 & -275 & -189 & -50 & -100 & -150 & -200 & 0 & 0 & 0 & 0 & 0 \\
\hline Foreign financing & 21 & 61 & 224 & 16 & 16 & 32 & 29 & 193 & 139 & 109 & 59 & 56 \\
\hline Loan disbursement & 69 & 140 & 279 & 30 & 59 & 89 & 119 & 282 & 264 & 261 & 275 & 275 \\
\hline Project & 69 & 140 & 148 & 30 & 59 & 89 & 119 & 132 & 114 & 111 & 125 & 125 \\
\hline Budget support ${ }^{2}$ & 0 & 0 & 131 & 0 & 0 & 0 & 0 & 150 & 150 & 150 & 150 & 150 \\
\hline Amortization & -48 & -80 & -56 & -14 & -44 & -57 & -90 & -89 & -125 & -151 & -216 & -220 \\
\hline Financing gap ${ }^{2}$ & 0 & 241 & -17 & 140 & 166 & 203 & 314 & 45 & 0 & 0 & 0 & 0 \\
\hline Identified financing & 0 & 241 & 0 & 140 & 166 & 203 & 314 & 45 & 0 & 0 & 0 & 0 \\
\hline Remaining gap / Errors and omissions & 0 & 0 & -17 & 0 & 0 & 0 & 0 & 0 & 0 & 0 & 0 & 0 \\
\hline
\end{tabular}

Sources: Ministry of Finance; and IMF staff estimates.

${ }^{1}$ The 2008 amount represents a discrepancy between above- and below-the-line totals.

2 Disbursements of budget support loans and grants from multilateral creditors are recorded under "Foreign financing for budget support" and "Grants for budget support", respectively, in the year they are drawn, and under "Identified financing of financing gap" in projections.

Projected issuance of international bonds in 2011-14 for general budget financing are recorded under "Foreign financing for budget support."

${ }^{3}$ Includes proceeds from privatization, succession funds, and the use of the 2009 SDR allocations. 
Table 6. Bosnia and Herzegovina: Monetary Survey, 2008-15

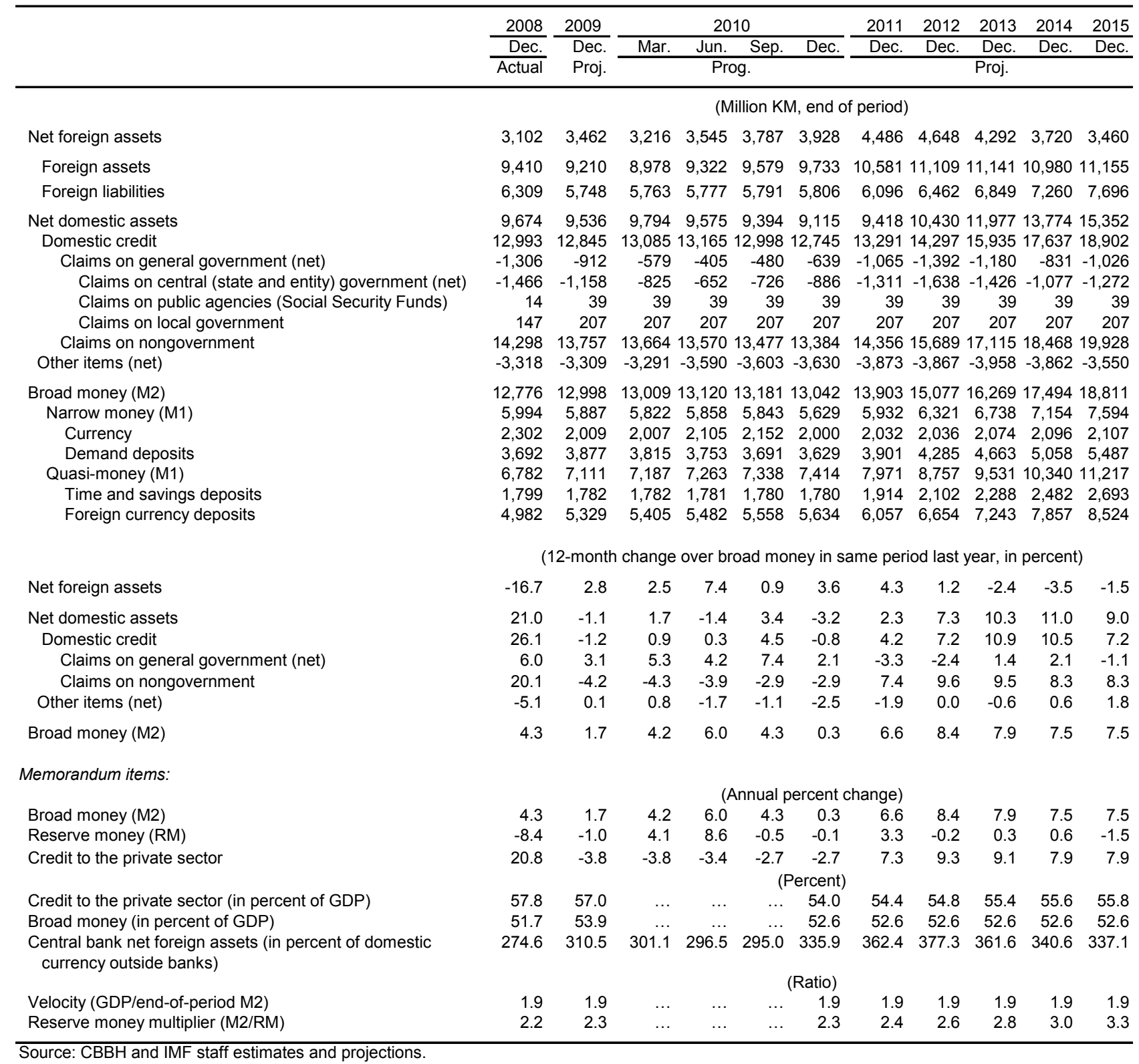


Table 7. Bosnia and Herzegovina: Central Bank and Commercial Banks, 2008-15 (Million KM, end of period)

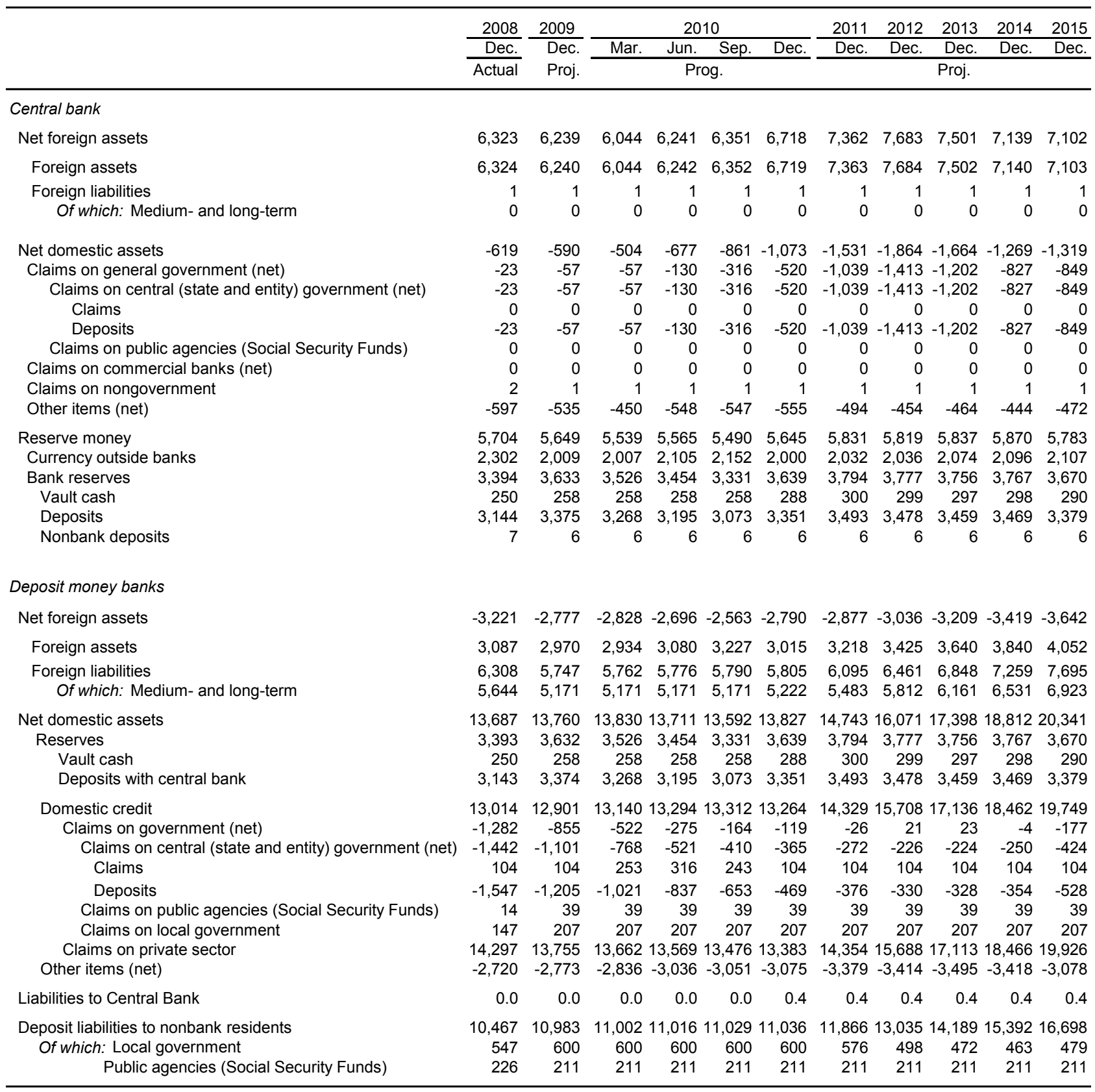

Source: CBBH and IMF staff estimates and projections. 
Table 8. Bosnia and Herzegovina: Financial Soundness Indicators, 2005-09

\begin{tabular}{|c|c|c|c|c|c|}
\hline & 2005 & 2006 & 2007 & 2008 & $\begin{array}{c}2009 \\
\text { Prel. }\end{array}$ \\
\hline \multicolumn{6}{|l|}{ Capital } \\
\hline Tier 1 capital to risk-weighted assets (RWA) & 13.7 & 13.6 & 12.6 & 12.0 & 12.4 \\
\hline Net capital to RWA & 17.8 & 17.7 & 17.1 & 16.3 & 15.7 \\
\hline \multicolumn{6}{|l|}{ Quality of assets } \\
\hline Nonperforming loans to total loans & 5.3 & 4.0 & 3.0 & 3.1 & 5.8 \\
\hline Nonperforming assets (NPAs) to total assets & 3.3 & 2.5 & 1.8 & 2.2 & 3.9 \\
\hline NPAs net of provisions to tier 1 capital & 20.4 & 15.2 & 12.9 & 14.3 & 25.6 \\
\hline Provision to NPAs & 40.1 & 39.6 & 37.2 & 37.9 & 34.4 \\
\hline \multicolumn{6}{|l|}{ Profitability } \\
\hline Return on assets & 0.7 & 0.9 & 0.9 & 0.4 & 0.1 \\
\hline Return on equity & 6.2 & 8.5 & 8.9 & 4.3 & 1.1 \\
\hline Net interest income to gross income & 54.1 & 54.3 & 59.9 & 60.6 & 61.5 \\
\hline Noninterest expenses to gross income & 90.1 & 86.4 & 84.9 & 90.5 & 96.7 \\
\hline \multicolumn{6}{|l|}{ Liquidity } \\
\hline Liquid assets to total assets & 36.1 & 35.9 & 37.7 & 30.0 & 30.9 \\
\hline Liquid assets to short- term financial liabilities & 61.9 & 60.8 & 61.3 & 51.8 & 52.9 \\
\hline Short- term financial liabilities to total financial liabilities & 66.1 & 67.1 & 69.0 & 65.4 & 66.1 \\
\hline \multicolumn{6}{|l|}{ Foreign exchange risk } \\
\hline Foreign currency and indexed loans to total loans & 68.7 & 71.0 & 74.0 & 73.3 & 73.9 \\
\hline Foreign currency liabilities to total financial liabilities & 64.4 & 62.8 & 65.0 & 69.5 & 69.2 \\
\hline Net open position & 8.3 & 8.9 & 4.9 & 6.2 & 1.7 \\
\hline
\end{tabular}

Source: CBBH. 
Table 9. Bosnia and Herzegovina: Baseline Medium-Term Outlook, 2007-15 ${ }^{1}$

\begin{tabular}{|c|c|c|c|c|c|c|c|c|c|}
\hline & 2007 & 2008 & 2009 & 2010 & 2011 & 2012 & 2013 & 2014 & 2015 \\
\hline & & & Est. & \multicolumn{6}{|c|}{ Projections } \\
\hline \multicolumn{10}{|l|}{ Real sector } \\
\hline Real GDP growth (percent) & 6.5 & 5.4 & -3.4 & 0.5 & 4.0 & 5.8 & 5.3 & 4.5 & 4.5 \\
\hline $\mathrm{CPI}$, period average percent change & 1.5 & 7.4 & -0.4 & 1.6 & 1.9 & 2.1 & 2.3 & 2.5 & 2.5 \\
\hline \multicolumn{10}{|c|}{ (In percent of GDP, unless otherwise indicated) } \\
\hline \multicolumn{10}{|l|}{ Savings and investment } \\
\hline Consumption & 107.4 & 108.0 & 104.4 & 102.8 & 100.4 & 99.8 & 98.8 & 98.2 & 97.6 \\
\hline Public & 19.4 & 20.5 & 20.6 & 20.4 & 19.4 & 19.2 & 19.1 & 18.8 & 18.7 \\
\hline Private & 88.0 & 87.5 & 83.8 & 82.4 & 81.0 & 80.6 & 79.7 & 79.3 & 78.9 \\
\hline Investment & 24.9 & 24.8 & 19.1 & 21.3 & 22.9 & 22.9 & 22.9 & 23.0 & 22.8 \\
\hline Public & 6.6 & 6.5 & 6.0 & 6.2 & 6.1 & 5.8 & 5.9 & 5.9 & 5.7 \\
\hline Private & 18.3 & 18.4 & 13.2 & 15.1 & 16.8 & 17.1 & 17.1 & 17.1 & 17.1 \\
\hline National savings & 12.3 & 9.9 & 11.6 & 14.0 & 15.9 & 15.9 & 16.6 & 17.2 & 17.1 \\
\hline Public & 5.1 & 0.9 & -0.2 & 0.9 & 2.4 & 3.3 & 4.0 & 4.7 & 5.1 \\
\hline Private & 7.2 & 9.0 & 11.8 & 13.1 & 13.4 & 12.6 & 12.6 & 12.5 & 12.1 \\
\hline Foreign savings & 12.6 & 14.9 & 7.5 & 7.3 & 7.1 & 7.0 & 6.3 & 5.8 & 5.7 \\
\hline \multicolumn{10}{|l|}{ General government } \\
\hline Total revenue and grants & 47.2 & 45.5 & 44.1 & 44.3 & 44.3 & 44.7 & 44.8 & 44.9 & 44.9 \\
\hline o/w Grants & 3.1 & 2.2 & 1.8 & 1.9 & 1.9 & 1.9 & 1.9 & 1.9 & 1.8 \\
\hline Total expenditure & 47.3 & 50.3 & 49.4 & 48.8 & 47.2 & 46.4 & 46.0 & 45.4 & 44.9 \\
\hline Current & 40.6 & 43.8 & 43.4 & 42.7 & 41.1 & 40.7 & 40.1 & 39.5 & 39.2 \\
\hline Capital & 6.6 & 6.5 & 6.0 & 6.2 & 6.1 & 5.8 & 5.9 & 5.9 & 5.7 \\
\hline Overall balance & -0.1 & -4.8 & -5.3 & -4.5 & -2.9 & -1.7 & -1.1 & -0.5 & 0.0 \\
\hline Overall balance excl. grants & -3.3 & -7.0 & -7.1 & -6.4 & -4.8 & -3.6 & -3.0 & -2.4 & -1.8 \\
\hline Public debt (percent of GDP) & 32.9 & 30.8 & 33.4 & 38.1 & 38.5 & 36.9 & 33.1 & 28.8 & 25.7 \\
\hline \multicolumn{10}{|l|}{ Balance of payments } \\
\hline Current account balance (percent of GDP) & -12.6 & -14.9 & -7.5 & -7.3 & -7.1 & -7.0 & -6.3 & -5.8 & -5.7 \\
\hline Export growth rate (percent) & 15.0 & 13.9 & -20.0 & 9.7 & 8.8 & 7.0 & 8.0 & 6.6 & 6.3 \\
\hline Import growth rate (percent) & 18.7 & 15.3 & -24.5 & 7.2 & 6.1 & 6.0 & 6.0 & 5.8 & 4.6 \\
\hline \multirow[t]{2}{*}{ Gross reserves (months of imports of GNFS) } & 4.7 & 5.7 & 5.3 & 5.4 & 5.6 & 5.5 & 5.1 & 4.6 & 4.6 \\
\hline & \multicolumn{9}{|c|}{ (In percent of exports of goods and services) } \\
\hline Total external debt service & 8.0 & 8.9 & 11.8 & 13.1 & 12.8 & 13.1 & 15.6 & 18.3 & 14.4 \\
\hline Memorandum item: GDP, millions of KM & 21,759 & 24,717 & 24,121 & 24,775 & 26,411 & 28,641 & 30,904 & 33,231 & 35,734 \\
\hline
\end{tabular}

Sources: BiH authorities; and IMF staff estimates and projections.

${ }^{1}$ On the basis of recommended policies. 
Table 10a. Bosnia and Herzegovina: Gross Financing Requirements 2008-15 (In millions of euros)

\begin{tabular}{|c|c|c|c|c|c|c|c|c|}
\hline & 2008 & 2009 & 2010 & 2011 & 2012 & 2013 & 2014 & 2015 \\
\hline Financing requirements & 2,146 & 1,195 & 1,240 & 1,285 & 1,390 & 1,533 & 1,710 & 1,578 \\
\hline Current account deficit & 1,879 & 921 & 930 & 953 & 1,018 & 996 & 981 & 1,039 \\
\hline Amortization & 267 & 274 & 310 & 332 & 373 & 537 & 728 & 539 \\
\hline Government, excluding IMF repurchases & 60 & 77 & 120 & 142 & 180 & 334 & 510 & 311 \\
\hline Other & 207 & 196 & 191 & 190 & 193 & 203 & 218 & 228 \\
\hline Financing & 2,146 & 1,195 & 1,240 & 1,285 & 1,390 & 1,533 & 1,710 & 1,578 \\
\hline Capital transfers & 198 & 191 & 195 & 210 & 215 & 221 & 226 & 232 \\
\hline FDI & 717 & 300 & 350 & 678 & 728 & 758 & 778 & 778 \\
\hline Net bank financing & 962 & -227 & 7 & 44 & 81 & 88 & 108 & 114 \\
\hline Foreign loans & 664 & 717 & 367 & 468 & 453 & 495 & 542 & 569 \\
\hline Government & 382 & 539 & 181 & 263 & 228 & 246 & 268 & 269 \\
\hline Other & 282 & 178 & 187 & 205 & 226 & 248 & 273 & 300 \\
\hline Gross international reserves $(-=$ increase $)$ & 206 & 45 & -245 & -329 & -164 & 93 & 185 & 19 \\
\hline Other & -601 & 169 & -145 & -110 & -114 & -122 & -129 & -134 \\
\hline Financing gap ${ }^{1}$ & $\ldots$ & $\ldots$ & 712 & 323 & 191 & 0 & 0 & 0 \\
\hline Fiscal & $\ldots$ & $\ldots$ & 475 & 58 & 0 & $\ldots$ & $\ldots$ & $\ldots$ \\
\hline Augmentation of reserves & $\ldots$ & $\ldots$ & 237 & 265 & 191 & $\ldots$ & $\ldots$ & $\ldots$ \\
\hline IMF & $\ldots$ & $\ldots$ & 474 & 265 & 191 & $\ldots$ & $\ldots$ & $\ldots$ \\
\hline World Bank & $\ldots$ & $\ldots$ & 138 & 58 & 0 & $\ldots$ & $\ldots$ & $\ldots$ \\
\hline EU & $\ldots$ & $\ldots$ & 100 & 0 & 0 & $\ldots$ & $\ldots$ & $\ldots$ \\
\hline Other (including London Club debt deferment) & $\ldots$ & $\ldots$ & 0 & 0 & 0 & $\ldots$ & $\ldots$ & $\ldots$ \\
\hline
\end{tabular}

Table 10b. Bosnia and Herzegovina: Gross Financing Requirements 2008-15 (In percent of GDP)

\begin{tabular}{|c|c|c|c|c|c|c|c|c|}
\hline & 2008 & 2009 & 2010 & 2011 & 2012 & 2013 & 2014 & 2015 \\
\hline Financing requirements & 17.0 & 9.7 & 9.8 & 9.5 & 9.5 & 9.7 & 10.1 & 8.6 \\
\hline Current account deficit & 14.9 & 7.5 & 7.3 & 7.1 & 7.0 & 6.3 & 5.8 & 5.7 \\
\hline Amortization & 2.1 & 2.2 & 2.4 & 2.5 & 2.5 & 3.4 & 4.3 & 2.9 \\
\hline Government, excluding IMF repurchases & 0.5 & 0.6 & 0.9 & 1.1 & 1.2 & 2.1 & 3.0 & 1.7 \\
\hline Other & 1.6 & 1.6 & 1.5 & 1.4 & 1.3 & 1.3 & 1.3 & 1.2 \\
\hline Financing & 17.0 & 9.7 & 9.8 & 9.5 & 9.5 & 9.7 & 10.1 & 8.6 \\
\hline Capital transfers & 1.6 & 1.5 & 1.5 & 1.6 & 1.5 & 1.4 & 1.3 & 1.3 \\
\hline FDI & 5.7 & 2.4 & 2.8 & 5.0 & 5.0 & 4.8 & 4.6 & 4.3 \\
\hline Net bank financing & 7.6 & -1.8 & 0.1 & 0.3 & 0.6 & 0.6 & 0.6 & 0.6 \\
\hline Foreign loans & 5.3 & 5.8 & 2.9 & 3.5 & 3.1 & 3.1 & 3.2 & 3.1 \\
\hline Government & 3.0 & 4.4 & 1.4 & 1.9 & 1.6 & 1.6 & 1.6 & 1.5 \\
\hline Other & 2.2 & 1.4 & 1.5 & 1.5 & 1.5 & 1.6 & 1.6 & 1.6 \\
\hline Gross international reserves $(-=$ increase $)$ & 1.6 & 0.4 & -1.9 & -2.4 & -1.1 & 0.6 & 1.1 & 0.1 \\
\hline Other & -4.8 & 1.4 & -1.1 & -0.8 & -0.8 & -0.8 & -0.8 & -0.7 \\
\hline Financing gap ${ }^{1}$ & $\ldots$ & $\ldots$ & 5.6 & 2.4 & 1.3 & 0.0 & 0.0 & 0.0 \\
\hline Fiscal & $\ldots$ & $\ldots$ & 3.7 & 0.4 & 0.0 & $\ldots$ & $\ldots$ & $\ldots$ \\
\hline Augmentation of reserves & $\ldots$ & $\ldots$ & 1.9 & 2.0 & 1.3 & $\ldots$ & $\ldots$ & $\ldots$ \\
\hline IMF & $\ldots$ & $\ldots$ & 3.7 & 2.0 & 1.3 & $\ldots$ & $\ldots$ & $\ldots$ \\
\hline World Bank & $\ldots$ & $\ldots$ & 1.1 & 0.4 & 0.0 & $\ldots$ & $\ldots$ & $\ldots$ \\
\hline EU & $\cdots$ & $\cdots$ & 0.8 & 0.0 & 0.0 & $\ldots$ & $\ldots$ & $\ldots$ \\
\hline Other (including London Club debt deferment) & $\ldots$ & $\ldots$ & 0.0 & 0.0 & 0.0 & $\ldots$ & $\ldots$ & $\ldots$ \\
\hline
\end{tabular}

Source: IMF staff projections and calculations.

${ }^{1}$ Disbursements of budget support loans and grants from multilateral creditors (incl. IMF) are recorded under

"Foreign loans" and "Current transfers", respectively, in the year they are drawn, and under "Identified financing of

financing gap" in projections. 
Table 11. Bosnia and Herzegovina: Indicators of Capacity to Repay the Fund, 2008-15

\begin{tabular}{|c|c|c|c|c|c|c|c|c|}
\hline & 2008 & 2009 & 2010 & 2011 & 2012 & 2013 & 2014 & 2015 \\
\hline & Est. & \multicolumn{7}{|c|}{ Projections } \\
\hline \multicolumn{9}{|l|}{ Fund repurchases and charges } \\
\hline In millions of SDRs & & 1.3 & 5.5 & 9.6 & 35.6 & 174.5 & 322.8 & 319.0 \\
\hline In millions of U.S. dollars & & 2.1 & 8.6 & 14.8 & 55.1 & 270.0 & 499.5 & 494.4 \\
\hline In percent of exports of goods and NFS & & 0.0 & 0.1 & 0.2 & 0.8 & 3.9 & 6.7 & 6.4 \\
\hline In percent of debt service & & 1.2 & 4.9 & 5.9 & 19.1 & 75.8 & 120.9 & 94.2 \\
\hline In percent of quota & & 0.8 & 3.3 & 5.7 & 21.1 & 103.3 & 190.9 & 188.9 \\
\hline In percent of gross official reserves & & 0.0 & 0.2 & 0.3 & 1.0 & 5.2 & 10.2 & 10.2 \\
\hline \multicolumn{9}{|l|}{ Fund credit outstanding } \\
\hline In millions of SDRs & & 182.6 & 608.8 & 845.5 & 991.8 & 829.4 & 516.2 & 202.9 \\
\hline In millions of U.S. dollars & & 281.7 & 943.5 & $1,306.7$ & $1,533.5$ & $1,283.2$ & 798.9 & 314.5 \\
\hline In percent of quota & & 108.0 & 360.0 & 500.0 & 586.5 & 490.5 & 305.2 & 120.0 \\
\hline In percent of GDP & & 1.6 & 5.3 & 7.0 & 7.6 & 6.0 & 3.5 & 1.3 \\
\hline In percent of gross official reserves & & 6.1 & 19.9 & 25.3 & 28.7 & 24.7 & 16.3 & 6.5 \\
\hline \multicolumn{9}{|l|}{ Memorandum items: } \\
\hline Exports of goods and services (millions of US\$) & 6,840 & 5,335 & 5,771 & 6,174 & 6,547 & 7,003 & 7,419 & $7,772.6$ \\
\hline Debt service (millions of US\$) & 172 & 175 & 251 & 288 & 356 & 413 & 525 & 536 \\
\hline Quota (millions of SDRs) & 169 & 169 & 169 & 169 & 169 & 169 & 169 & 169 \\
\hline Quota (millions of US\$) & 267 & 261 & 262 & 261 & 261 & 262 & 262 & 262 \\
\hline Gross official reserves (millions of US\$) & 4,385 & 4,637 & 4,738 & 5,155 & 5,348 & 5,187 & 4,905 & 4,850 \\
\hline GDP (millions of US\$) & 18,512 & 17,133 & 17,641 & 18,615 & 20,063 & 21,512 & 22,986 & 24,565 \\
\hline
\end{tabular}

Source: Fund staff estimates. 
Table 12. Bosnia and Herzegovina: Performance Criteria Under the 2009-12 Stand-By Arrangement, 2009 (In millions of KM)

\begin{tabular}{|c|c|c|c|c|c|c|}
\hline & \multirow{4}{*}{$\begin{array}{c}\text { End-year stock } \\
2008 \\
\text { December } \\
\text { Actual }\end{array}$} & \multirow{2}{*}{\multicolumn{5}{|c|}{$\begin{array}{l}\text { Cummulative flow within the calendar year } \\
2009\end{array}$}} \\
\hline & & & & & & \\
\hline & & \multirow{2}{*}{$\begin{array}{c}\text { June } \\
\text { Actual }\end{array}$} & \multicolumn{2}{|c|}{ September } & \multicolumn{2}{|c|}{ Dec } \\
\hline & & & Program & Actual & Program & Actual \\
\hline \multicolumn{7}{|l|}{ Ceiling on accumulation of net credit of the banking system to: ${ }^{1}$} \\
\hline $\begin{array}{l}\text { General government } \\
\text { of which: }\end{array}$ & $-2,338$ & 261 & 476 & 156 & 676 & 309 \\
\hline State government & -412 & -89 & 44 & -69 & 44 & -30 \\
\hline RS government & $-1,109$ & 285 & 424 & 398 & 536 & 523 \\
\hline Federation government & -737 & 86 & 15 & -161 & 108 & -191 \\
\hline $\begin{array}{l}\text { Ceiling on new guarantees and the assumption of enterprise } \\
\text { debt to banks by the State, Federation and RS governments }{ }^{2}\end{array}$ & $\ldots$ & 0 & 0 & 0 & 0 & 0 \\
\hline Ceiling on accumulation external debt service arrears ${ }^{2}$ & $\ldots$ & 0 & 0 & 0 & 0 & 0 \\
\hline $\begin{array}{l}\text { Ceiling on contracting new short-term external } \\
\text { nonconcessional debt }{ }^{2}\end{array}$ & $\ldots$ & 0 & 0 & 0 & 0 & 0 \\
\hline \multicolumn{7}{|l|}{ Ceiling on accumulation of domestic arrears of: ${ }^{2}$} \\
\hline State government & $\ldots$ & 0 & 0 & 0 & 0 & 0 \\
\hline RS government & $\ldots$ & 0 & 0 & 0 & 0 & 0 \\
\hline Federation government & $\ldots$ & 0 & 0 & 0 & 0 & 0 \\
\hline
\end{tabular}

${ }^{1}$ Cumulative within each calendar year. Equal to the sum of the three listed sub-ceilings plus the net bank credit to the District of Brčko, which is not monitored individually due to its small size.

${ }^{2}$ Continuous. 
Table 13. Bosnia and Herzegovina: Performance Criteria Under the 2009-12 Stand-By Arrangement, 2010 (In millions of KM)

\begin{tabular}{|c|c|c|c|c|c|}
\hline & \multirow{3}{*}{$\begin{array}{c}\text { Stock } \\
2009 \\
\text { December } \\
\end{array}$} & \multicolumn{4}{|c|}{ Cumulative flow since the beginning of the referenced year } \\
\hline & & \multicolumn{4}{|c|}{2010} \\
\hline & & March & June & September & December \\
\hline & Actual & Program & Program & Ind target & Ind target \\
\hline \multicolumn{6}{|l|}{ Ceiling on accumulation of net credit of the banking system to: ${ }^{1,2}$} \\
\hline $\begin{array}{l}\text { General government } \\
\text { of which: }\end{array}$ & $-2,029$ & 333 & 580 & 759 & 845 \\
\hline State government & -442 & 20 & -11 & 75 & 122 \\
\hline RS government & -586 & 251 & 429 & 564 & 638 \\
\hline Federation government & -928 & 61 & 164 & 122 & 91 \\
\hline $\begin{array}{l}\text { Ceiling on new guarantees and the assumption of enterprise debt to banks } \\
\text { by the State, Federation and RS governments }{ }^{3}\end{array}$ & $\ldots$ & 0 & 0 & 0 & 0 \\
\hline Ceiling on accumulation external debt service arrears ${ }^{3}$ & $\ldots$ & 0 & 0 & 0 & 0 \\
\hline $\begin{array}{l}\text { Ceiling on contracting new short-term external } \\
\text { nonconcessional debt }{ }^{3}\end{array}$ & $\ldots$ & 0 & 0 & 0 & 0 \\
\hline \multicolumn{6}{|l|}{ Ceiling on accumulation of domestic arrears of: ${ }^{3}$} \\
\hline State government & $\ldots$ & 0 & 0 & 0 & 0 \\
\hline RS government & $\ldots$ & 0 & 0 & 0 & 0 \\
\hline Federation government & $\ldots$ & 0 & 0 & 0 & 0 \\
\hline
\end{tabular}

\footnotetext{
${ }^{1}$ Equal to the sum of the three listed sub-ceilings plus the net bank credit to the District of Brčko, which is not monitored individually due to its small size.

${ }^{2}$ The targets on banking system net claims the general government will be adjusted upward (downward) by the full amount of any shortfall (surplus) in programmed disbursements of budget support loans and grants; and will also be adjusted upward (downward) by the amount by which reported change in float is arithmetically smaller (greater) than its targets in the fiscal program. The upward adjustment is limited to 10 percent of the absolute value of the respective change-in-float target (see Technical Memorandum of Understanding on Definitions and Reporting Under the 2009-12 Economic Program).

${ }^{3}$ Continuous.
} 
Table 14. Bosnia and Herzegovina: Performance for the First Review under the 2009-12 Stand-By Arrangement

\begin{tabular}{|c|c|c|c|}
\hline & & Target date & Status \\
\hline I. & Quantitative performance criteria & & \\
\hline 1. & $\begin{array}{l}\text { Ceiling on accumulation of net credit of the banking system to: } \\
\text { general government } \\
\text { State government } \\
\text { RS government } \\
\text { Federation government }\end{array}$ & December 2009 & $\begin{array}{l}\text { observed } \\
\text { observed } \\
\text { observed } \\
\text { observed }\end{array}$ \\
\hline 2. & $\begin{array}{l}\text { Ceiling on new guarantees and assumption of enterprise debt to banks by the State, } \\
\text { Federation and RS governments }\end{array}$ & December 2009 & observed \\
\hline 3. & Ceiling on accumulation of external payment arrears & December 2009 & observed \\
\hline 4. & Ceiling on contracting new short-term external nonconcessional debt & December 2009 & observed \\
\hline 5. & $\begin{array}{l}\text { Ceiling on accumulation of domestic payment arrears } \\
\text { State government } \\
\text { RS government } \\
\text { Federation government }\end{array}$ & December 2009 & $\begin{array}{l}\text { observed } \\
\text { observed } \\
\text { observed }\end{array}$ \\
\hline II. & Current Structural Benchmarks & & \\
\hline A. & Continued adherence of the Currency Board Arrangement as constituted under the law & continuous & observed \\
\hline B. & Fiscal Sector & & \\
\hline 1. & Approve the rebalanced budgets by the Entity Parliaments & end-August 2009 & observed \\
\hline 2. & $\begin{array}{l}\text { Agree on an action plan acceptable to the World Bank and IMF staffs to reform the system of } \\
\text { rights-based transfers (Federation) }\end{array}$ & end-November 2009 & observed with delay \\
\hline 3. & Submit to the Parliament a Law forbidding passing of unfunded legislation (Federation) & end-November 2009 & observed with delay \\
\hline 4. & $\begin{array}{l}\text { Publish on the State government's web site quarterly consolidated general government } \\
\text { accounts with a } 5 \text { week lag }\end{array}$ & continuous & $\begin{array}{l}\text { observed partially, with } \\
\text { delay }\end{array}$ \\
\hline C. & Financial Sector & & \\
\hline 1. & $\begin{array}{l}\text { Form a standing committee of financial stability and sign the MoU on financial stability, crisis } \\
\text { preparedness and crisis management }\end{array}$ & end-November 2009 & observed with delay \\
\hline 2. & $\begin{array}{l}\text { The Deposit Insurance Agency to impose a principle of universal membership requirements, } \\
\text { including for partially state-owned banks }\end{array}$ & end-February 2010 & observed \\
\hline \multirow[t]{2}{*}{ III. } & Proposed New Conditionality & & \\
\hline & Prior Actions & & \\
\hline 1. & $\begin{array}{l}\text { Approve by State and Entity Parliaments } 2010 \text { budgets consistent with the program, including } \\
\text { supporting legislation }\end{array}$ & & met \\
\hline 2. & $\begin{array}{l}\text { Enact by Entity Parliaments framework legislation in preparation for the transition to a means- } \\
\text { tested system of rights-based benefits (Federation, RS) }\end{array}$ & & met \\
\hline \multirow[t]{2}{*}{3.} & $\begin{array}{l}\text { Enact law to eliminate special unemployment benefits granted to demobilized soldiers } \\
\text { effective May 1, } 2010 \text { (Federation) }\end{array}$ & & met \\
\hline & Structural Benchmarks & & \\
\hline 1. & $\begin{array}{l}\text { Carry out eligibility audits for civil and war benefit recipients; publish results (quarterly within } 4 \\
\text { weeks after the end of each quarter) of audits, including expected savings from } \\
\text { disqualifications (Federation, RS) }\end{array}$ & continuous & \\
\hline 2. & $\begin{array}{l}\text { Adopt by Parliament wage legislation consistent with the } 2010 \text { fiscal policy objectives } \\
\text { (Federation) }\end{array}$ & end-March 2010 & \\
\hline 3. & Reform privileged pensions by entity governments (Federation, RS) & end-March 2010 & \\
\hline 4. & Prepare a strategy for pension reform by entity governments (Federation, RS) & end-March 2010 & \\
\hline
\end{tabular}


Table 15. Bosnia and Herzegovina: Schedule of Purchases Under the Stand-By Arrangement, 2009-12

\begin{tabular}{|c|c|c|c|}
\hline \multirow[b]{2}{*}{$\begin{array}{l}\text { Available on } \\
\text { or after }\end{array}$} & \multicolumn{2}{|c|}{ Amount of Purchase } & \multirow[b]{2}{*}{ Conditions } \\
\hline & $\begin{array}{l}\text { In millions } \\
\text { of SDRs }\end{array}$ & $\begin{array}{l}\text { In percent } \\
\text { of quota }{ }^{1}\end{array}$ & \\
\hline 1 July 8, 2009 & 182.63 & 108 & Board approval of the arrangement. \\
\hline 2 December 10, 2009 & 87.93 & 52 & $\begin{array}{l}\text { Observance of end-September } 2009 \text { performance criteria and } \\
\text { completion of the first program review. }\end{array}$ \\
\hline 3 March 10, 2010 & 33.82 & 20 & $\begin{array}{l}\text { Observance of end-December } 2009 \text { performance criteria, and } \\
\text { completion of the quarterly program review. }\end{array}$ \\
\hline 4 June 10, 2010 & 33.82 & 20 & $\begin{array}{l}\text { Observance of end-March } 2010 \text { performance criteria and } \\
\text { completion of the quarterly program review. }\end{array}$ \\
\hline 5 September 10, 2010 & 135.28 & 80 & $\begin{array}{l}\text { Observance of end-June } 2010 \text { performance criteria and } \\
\text { completion of the quarterly program review. }\end{array}$ \\
\hline 6 December 10, 2010 & 135.28 & 80 & $\begin{array}{l}\text { Observance of end-September } 2010 \text { performance criteria and } \\
\text { completion of the quarterly program review. }\end{array}$ \\
\hline 7 March 10, 2011 & 33.82 & 20 & $\begin{array}{l}\text { Observance of end-December } 2010 \text { performance criteria and } \\
\text { completion of the quarterly program review. }\end{array}$ \\
\hline 8 June 10, 2011 & 33.82 & 20 & $\begin{array}{l}\text { Observance of end-March } 2011 \text { performance criteria and } \\
\text { completion of the quarterly program review. }\end{array}$ \\
\hline 9 September 10, 2011 & 84.55 & 50 & $\begin{array}{l}\text { Observance of end-June } 2011 \text { performance criteria and } \\
\text { completion of the quarterly program review. }\end{array}$ \\
\hline 10 December 10, 2011 & 84.55 & 50 & $\begin{array}{l}\text { Observance of end-September } 2011 \text { performance criteria and } \\
\text { completion of the quarterly program review. }\end{array}$ \\
\hline 11 March 10, 2012 & 84.55 & 50 & $\begin{array}{l}\text { Observance of end-December } 2011 \text { performance criteria and } \\
\text { completion of the quarterly program review. }\end{array}$ \\
\hline 12 June 10, 2012 & 84.55 & 50 & $\begin{array}{l}\text { Observance of end-March } 2012 \text { performance criteria and } \\
\text { completion of the quarterly program review. }\end{array}$ \\
\hline Total & $1,014.60$ & 600 & \\
\hline
\end{tabular}

${ }^{1}$ The quota is SDR 169.1 million. 
Appendix Figure 1. Bosnia and Herzegovina: External Debt Sustainability: Bound Tests ${ }^{1}$ (External debt in percent of GDP)

Baseline and historical scenarios

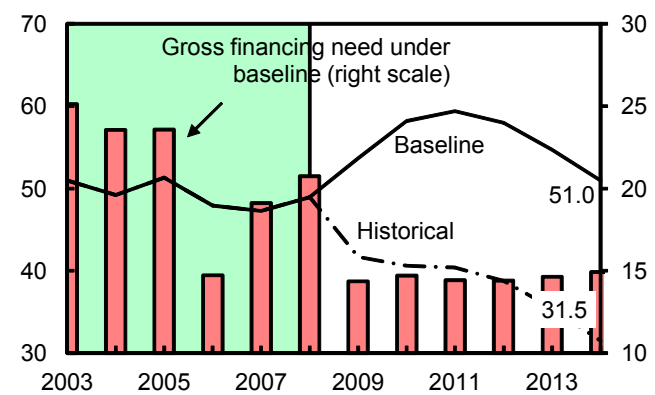

Growth shock (percent per year)

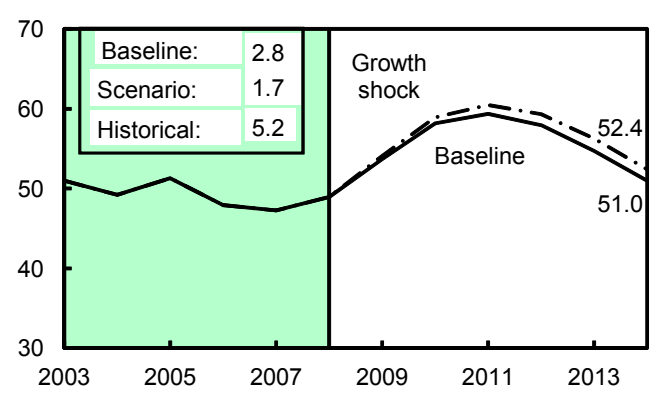

Combined shock ${ }^{2}$

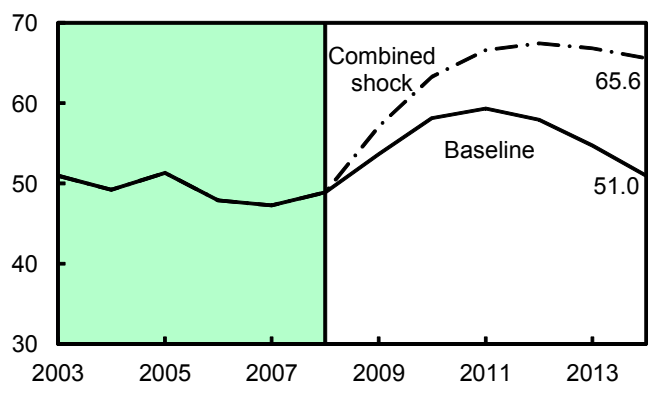

Interest rate shock (percent)

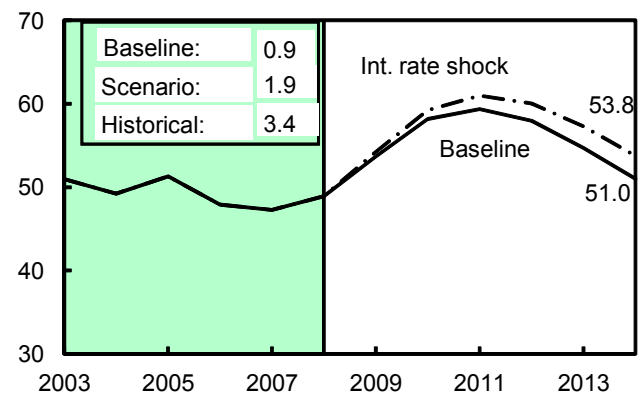

Non-interest current account shock (percent of GDP)

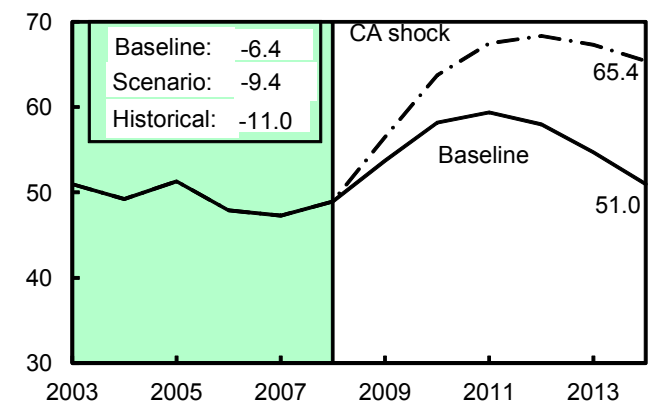

Sources: International Monetary Fund, Country desk data, and staff estimates.

${ }^{1}$ Shaded areas represent actual data. Individual shocks are permanent one-half standard deviation shocks. Figures in the boxes represent average projections for the respective variables in the baseline and scenario being presented. Ten-year historical average for the variable is also shown.

2 Permanent $1 / 4$ standard deviation shocks applied to real interest rate, growth rate, and current account balance.

${ }^{3}$ One-time real depreciation of 30 percent occurs in 2009. 
Appendix Figure 2. Bosnia and Herzegovina: Public Debt Sustainability: Bound Tests ${ }^{1}$ (Public debt in percent of GDP)

Baseline and historical scenarios

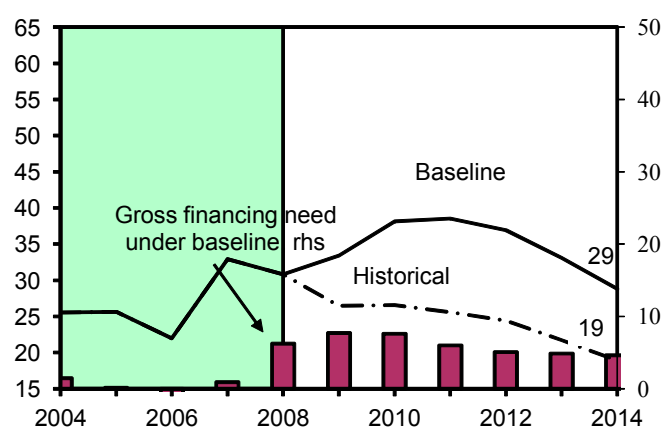

Growth shock (in percent per year)

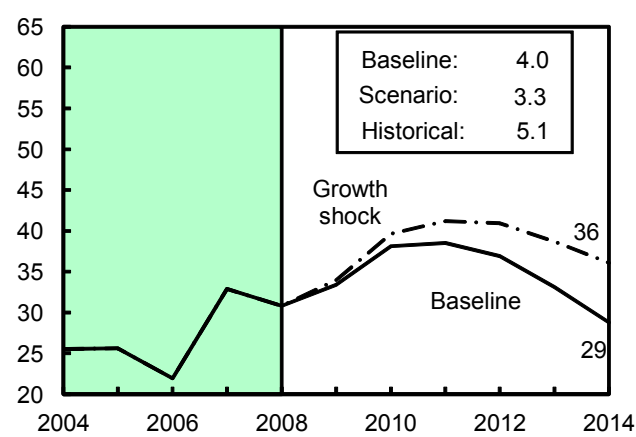

Interest rate shock (in percent)

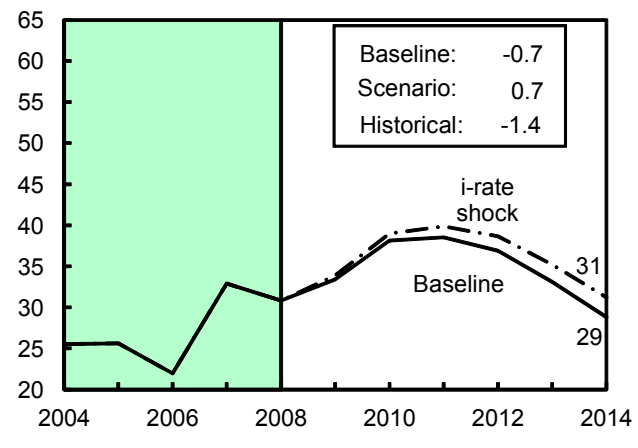

Primary balance shock and constant primary balance scenario (in percent of GDP)

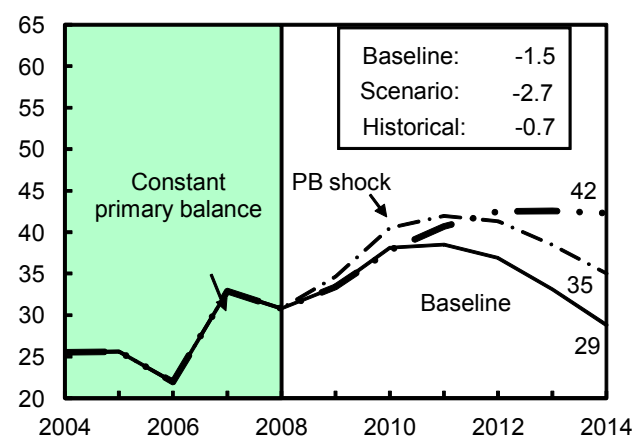

Combined shock ${ }^{2}$

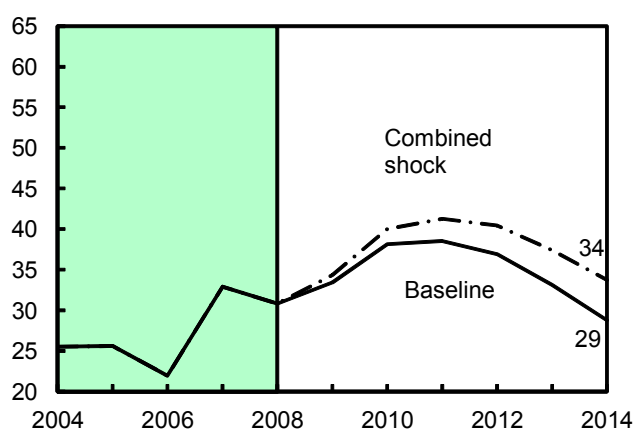

Real depreciation and contingent liabilities shocks ${ }^{3}$

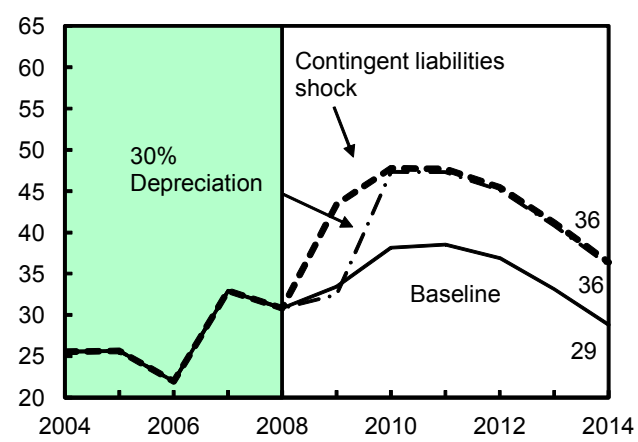

Sources: International Monetary Fund, country desk data, and staff estimates.

1 Shaded areas represent actual data. Individual shocks are permanent one-half standard deviation shocks. Figures in the boxes represent average projections for the respective variables in the baseline and scenario being presented. Ten-year historical average for the variable is also shown

2 Permanent $1 / 4$ standard deviation shocks applied to real interest rate, growth rate, and primary balance.

3 One-time real depreciation of 30 percent and 10 percent of GDP shock to contingent liabilities occur in 2009, with real depreciation defined as nominal depreciation (measured by percentage fall in dollar value of local currency) minus domestic inflation (based on GDP deflator). 
Appendix Table 1. Bosnia and Herzegovina: External Debt Sustainability Framework, 2005-2014

(In percent of GDP, unless otherwise indicated)

\begin{tabular}{|c|c|c|c|c|c|c|c|c|c|c|c|c|}
\hline & & \multicolumn{4}{|c|}{ Actual } & \multicolumn{6}{|c|}{ Projections } & \multirow{2}{*}{$\begin{array}{l}\text { Debt-stabilizing } \\
\text { non-interest } \\
\text { current account }\end{array}$} \\
\hline & & 2005 & 2006 & 2007 & 2008 & 2009 & 2010 & 2011 & 2012 & 2013 & 2014 & \\
\hline \multicolumn{2}{|c|}{1 Baseline: External debt } & 51.3 & 47.9 & 47.3 & 48.9 & 53.7 & 58.2 & 59.4 & 58.0 & 54.7 & 51.0 & -8.8 \\
\hline \multirow{2}{*}{\multicolumn{2}{|c|}{$\begin{array}{l}2 \text { Change in external debt } \\
3 \text { Identified external debt-creating flows }(4+8+9)\end{array}$}} & 2.1 & -3.4 & -0.6 & 1.7 & 4.8 & 4.5 & 1.2 & -1.4 & -3.2 & -3.7 & \\
\hline & & 3.9 & -8.2 & -13.5 & 0.0 & 7.4 & 1.5 & -2.5 & -3.8 & -3.8 & -3.4 & \\
\hline 4 & Current account deficit, excluding interest payments & 17.0 & 7.4 & 11.4 & 14.2 & 7.1 & 6.9 & 6.6 & 6.4 & 5.8 & 5.4 & \\
\hline 5 & Deficit in balance of goods and services & 41.1 & 29.7 & 32.3 & 32.9 & 23.5 & 24.1 & 23.4 & 22.7 & 21.8 & 21.2 & \\
\hline 6 & Exports & 32.7 & 36.7 & 36.5 & 37.0 & 31.1 & 32.7 & 33.1 & 32.6 & 32.5 & 32.3 & \\
\hline 7 & Imports & 73.9 & 66.5 & 68.8 & 69.8 & 54.7 & 56.8 & 56.5 & 55.3 & 54.3 & 53.4 & \\
\hline 8 & Net non-debt creating capital inflows (negative) & -10.9 & -10.3 & -16.9 & -6.2 & -4.0 & -4.3 & -6.6 & -6.4 & -6.2 & -5.9 & \\
\hline 9 & Automatic debt dynamics ${ }^{1}$ & -2.3 & -5.3 & -7.9 & -7.9 & 4.3 & -1.1 & -2.6 & -3.7 & -3.4 & -2.9 & \\
\hline 10 & Contribution from nominal interest rate & 1.0 & 1.0 & 1.2 & 0.8 & 0.4 & 0.5 & 0.5 & 0.5 & 0.5 & 0.5 & \\
\hline 11 & Contribution from real GDP growth & -1.8 & -3.1 & -2.7 & -1.9 & 1.8 & -0.3 & -2.2 & -3.2 & -2.8 & -2.3 & \\
\hline 12 & Contribution from price and exchange rate changes ${ }^{2}$ & -1.4 & -3.1 & -6.5 & -6.8 & 2.1 & -1.3 & -0.8 & -1.1 & -1.1 & -1.0 & \\
\hline \multicolumn{2}{|r|}{13 Residual, incl. change in gross foreign assets $(2-3)^{3}$} & -1.8 & 4.8 & 12.8 & 1.6 & -2.6 & 3.0 & 3.7 & 2.3 & 0.5 & -0.3 & \\
\hline \multicolumn{2}{|r|}{ External debt-to-exports ratio (in percent) } & 156.8 & 130.4 & 129.5 & 132.4 & 172.4 & 177.9 & 179.1 & 177.7 & 168.2 & 158.1 & \\
\hline \multicolumn{2}{|r|}{ Gross external financing need (in billions of US dollars) ${ }^{4}$} & 2.5 & 1.8 & 2.9 & 3.8 & 2.5 & 2.6 & 2.7 & 2.9 & 3.1 & 3.4 & \\
\hline & in percent of GDP & 23.6 & 14.7 & 19.1 & 20.8 & 14.4 & 14.7 & 14.4 & 14.4 & 14.6 & 14.9 & \\
\hline \multicolumn{2}{|r|}{ Scenario with key variables at their historical averages ${ }^{5}$} & & & & & 41.7 & 40.6 & 40.4 & 38.8 & 35.5 & 31.5 & -14.6 \\
\hline \multicolumn{13}{|c|}{ Key Macroeconomic Assumptions Underlying Baseline } \\
\hline \multicolumn{2}{|r|}{ Real GDP growth (in percent) } & 3.9 & 6.9 & 6.8 & 4.9 & -3.4 & 0.5 & 4.0 & 5.8 & 5.3 & 4.5 & \\
\hline \multirow{2}{*}{\multicolumn{2}{|c|}{ GDP deflator in US dollars (change in percent) }} & 3.0 & 6.5 & 15.6 & 16.8 & -4.2 & 2.5 & 1.5 & 1.9 & 1.9 & 2.3 & \\
\hline & & 2.1 & 2.2 & 3.1 & 2.0 & 0.7 & 0.9 & 0.9 & 1.0 & 0.9 & 0.8 & \\
\hline & 19.6 & 27.7 & 23.6 & 22.9 & -22.0 & 8.1 & 7.0 & 6.0 & 7.0 & 5.9 & \\
\hline & 12.3 & 2.4 & 28.7 & 23.1 & -27.5 & 7.0 & 5.0 & 5.4 & 5.3 & 5.1 & \\
\hline \multirow{2}{*}{\multicolumn{2}{|c|}{$\begin{array}{l}\text { Current account balance, excluding interest payments } \\
\text { Net non-debt creating capital inflows }\end{array}$}} & -17.0 & -7.4 & -11.4 & -14.2 & -7.1 & -6.9 & -6.6 & -6.4 & -5.8 & -5.4 & \\
\hline & & 10.9 & 10.3 & 16.9 & 6.2 & 4.0 & 4.3 & 6.6 & 6.4 & 6.2 & 5.9 & \\
\hline
\end{tabular}

${ }_{1}^{1}$ Derived as $[r-g-r(1+g)+$ ea $(1+r)](1+g+r+g r)$ times previous period debt stock, with $r=$ nominal effective interest rate on external debt; $r=$ change in domestic GDP deflator in US dollar terms, $g$ = real GDP growth rate, $\mathrm{e}=$ nominal appreciation (increase in dollar value of domestic currency), and $\mathrm{a}=$ share of domestic-currency denominated debt in

${ }^{2}$ The contribution from price and exchange rate changes is defined as $[-r(1+g)+e a(1+r)] /(1+g+r+g r)$ times previous period debt stock. $r$ increases with an appreciating domestic currency $(e>0)$ and rising inflation (based on GDP deflator).

For projection, line includes the impact of price and exchange rate changes.

${ }^{4}$ Defined as current account deficit, plus amortization on medium- and long-term debt, plus short-term debt at end of previous period.

${ }^{5}$ The key variables include real GDP growth; nominal interest rate; dollar deflator growth; and both non-interest current account and non-debt inflows in percent of GDP.

Long-run, constant balance that stabilizes the debt ratio assuming that key variables (real GDP growth, nominal interest rate, dollar deflator growth, and non-debt inflows in

percent of GDP) remain at their levels of the last projection year. 
Appendix Table 2. Bosnia and Herzegovina: Public Sector Debt Sustainability Framework, 2005-14

(In percent of GDP, unless otherwise indicated)

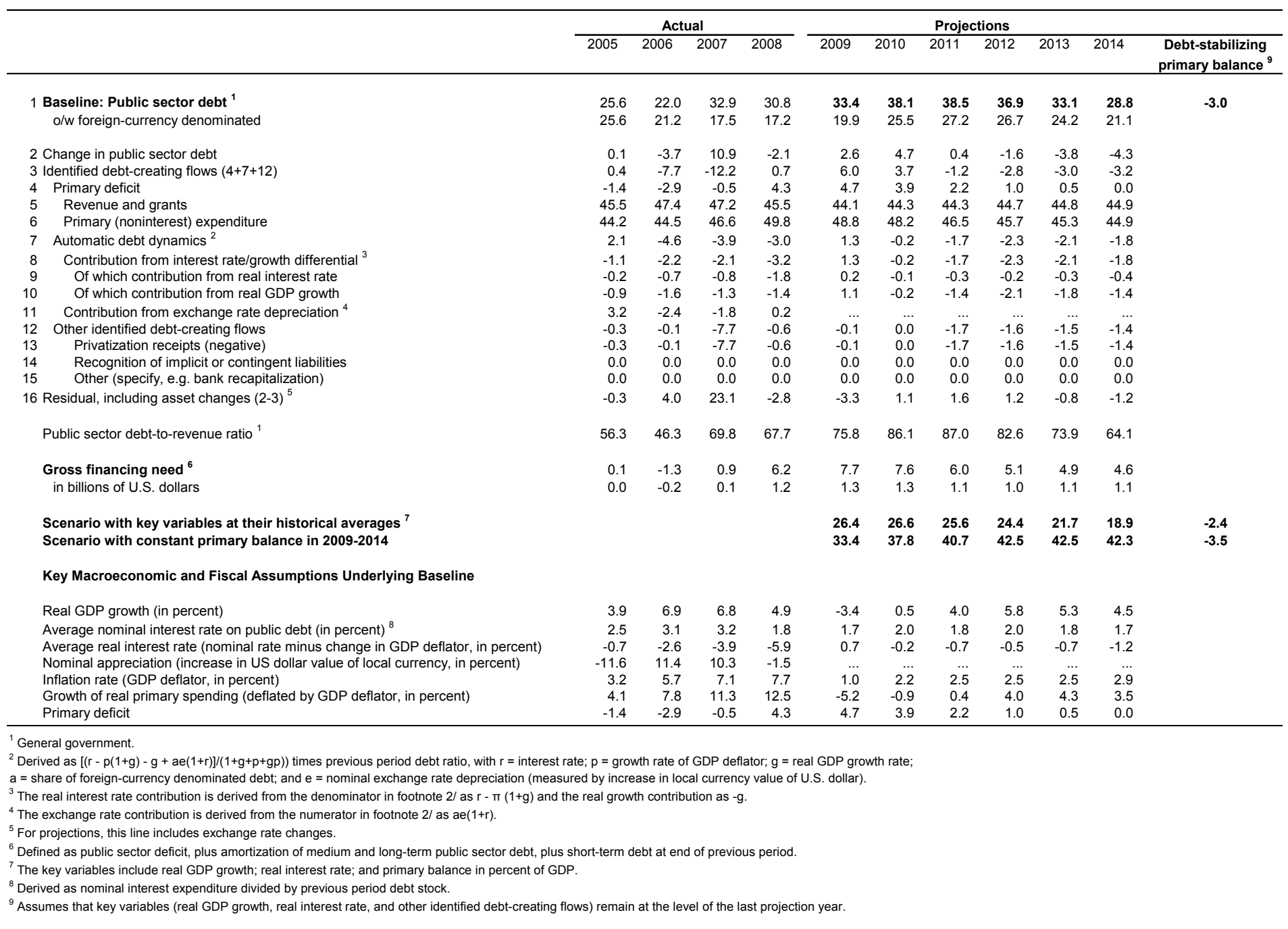

CInternational Monetary Fund. Not for Redistribution 


\title{
ATTACHMENT I. BOSNIA AND HERZEGOVINA: LETTER OF INTENT
}

\author{
Sarajevo and Banja Luka, Bosnia and Herzegovina
}

March 5, 2010

Mr. Dominique Strauss-Kahn

Managing Director

International Monetary Fund

Washington, D.C. 20431

Dear Mr. Strauss-Kahn:

1. The economy of Bosnia and Herzegovina $(\mathrm{BiH})$ has been adversely affected by the global financial and economic crisis. The impact of the crisis has been aggravated by underlying imbalances in our economy, raising concerns about macroeconomic stability and BiH's long-term prospects. Economic activity has been contracting, hit by declines in exports and domestic demand. However, recent indicators suggest that the pace of the contraction is slowing and we expect a gradual improvement in 2010. The current account deficit of the balance of payments is shrinking, and external financial strains have eased. Foreign banks have broadly maintained their exposure to $\mathrm{BiH}$, household deposits have resumed flowing into the banking system, and foreign exchange reserves have partly recovered.

2. Despite the challenging environment, policy implementation of the IMF-supported program has been broadly in line with our commitments (Tables 1 and 3). All quantitative performance criteria for end-September and end-December 2009 and structural benchmarks have been met albeit some with a delay. Regarding the structural benchmark for the publication on the State government's website of quarterly consolidated general government data (continuous structural benchmark), we have established a coordinating group with the task of collecting and consolidating fiscal statistics from all levels of government to ensure that we meet this benchmark on time in the future.

3. Although we were able to keep overall expenditures in check, revenue shortfalls led to a 2009 fiscal deficit outturn above the program objective, and ongoing fiscal pressures put achievement of the program's 2010 fiscal deficit objective at risk. We have thus identified corrective measures elaborated in this Letter. In view of this performance and our continued commitment to the program, we request completion of the first review under the Stand-By Arrangement.

4. The policies described in the letter of June 16, 2009 and in this Letter are adequate to achieve the objectives of our economic program, and we stand ready to take additional measures as appropriate to ensure the attainment of these objectives. As is standard under all 
IMF arrangements, we will consult with the IMF before modifying measures contained in this letter or adopting new measures that would deviate from the goals of the program, and provide the IMF with the necessary information for program monitoring.

\section{RECENT DEVELOPMENTS}

5. Since the beginning of 2009, the downturn has quickly spread across the economy and, as elsewhere in the region, the sharp drop in domestic demand has helped drive down imports substantially, while exports have declined as well, but by a lesser amount. As a result, the trade deficit is narrowing faster than initially projected, leading to a sharp contraction in the current account deficit. Inflation has declined sharply from near 10 percent in mid-2008 to zero by end-2009, partly aided by drops in food and energy prices.

6. Financial market stress has eased, reflecting an improvement in market sentiment. Nongovernment deposits have been flowing back into the banking system and central bank reserves have strengthened in large part owing to the first purchase under the SBA and the SDR allocation. Commercial banks are liquid but their reluctance to assume increased risk and the general worsening of the economic environment have brought credit growth to a halt.

7. However, because of uneven implementation of fiscal policy measures included in the program and revenue shortfalls, the general government deficit has been widening. We now estimate that the consolidated general government deficit in 2009 reached 5.3 percent of GDP compared with a deficit of 4.8 percent in 2008 and against a deficit objective of 4.7 percent under the program. Limiting the consolidated fiscal deficit to this level took substantial efforts from all governments (see below). The State budget is estimated to have recorded a surplus. In the Federation, the fiscal slippage is mainly attributed to revenue shortfalls, while overruns in current expenditure were partially compensated by cuts in capital spending. In the Republika Srpska (RS), shortfalls in indirect tax revenues have been more than offset by better than budgeted social contributions and direct taxes. However, overruns took place in the wage bill and pressures on the finances of the pension fund have been increasing.

\section{The Program}

8. The main objectives of the program remain to preserve macroeconomic and financial stability, safeguard the currency board, and cushion the effects of the adverse external environment. Uneven implementation of our commitments in the fiscal area will necessitate stronger efforts in the coming months. The fiscal consolidation and public sector wage restraint will ensure stability in the short term, but also bring us back on the path of fiscal sustainability. Fiscal policy measures will be accompanied by measures to strengthen the financial sector and ambitious structural reforms to improve public finance management, and the competitiveness of our economy, thus providing an environment conducive to robust private sector activity. 


\section{A. Macroeconomic Framework}

9. The macroeconomic framework has retained cautious assumptions. A gradual return to positive growth is projected, with GDP gaining about 0.5 percent in 2010 , aided by recovery in the euro area. Inflation is expected to pick up slightly, approaching $1 \frac{1}{2}$ percent by end-2010. While exports are expected to lead the recovery, imports are also projected to grow, but at a fairly modest rate. As a result, the current account deficit is expected to remain flat, but considerably below pre-crisis levels.

\section{B. Fiscal Policy}

10. Since the approval of the program in July 2009, we have maintained fiscal prudence. We prepared rebalanced budgets of the two Entity budgets incorporating all our commitments. Since the delay in completion of the first SBA review also delayed the second disbursement from the Fund, the Fiscal Council recommended distribution of the funds from the SDR allocations to the two Entities, which used them for budget financing (within the agreed deficit objectives).

11. The Institutions of Bosnia and Herzegovina have adopted the amendments to wage legislation, effective from July $1^{\text {st }}, 2009$, as agreed under the Letter of Intent as of June 16 2009. In addition, BiH Institutions have implemented saving measures in 2009 as instructed by the ministry of finance and treasury. These measures are estimated to have achieved a surplus of 0.1 percent of GDP in 2009.

12. The Federation exercised restraint in spending, at all levels of government and across all types of expenditures in 2009. However, given the further shortfalls in revenue collection, in particular of indirect tax revenues, the Ministry of Finance adopted a budget rebalance, which provided for further cuts of public revenues of KM 55 million.

13. In July 2009, the Federation Parliament passed a Law on Savings, providing for savings on wages, allowances, transfers and other current spending for the duration of the program on a temporary basis, and until new legislation reforming spending in these categories is designed and adopted.

14. In order to legally regulate the wage cuts for government employees and the employees of other institutions financed from the Federation budget, the government passed amendments and changes to the Law on Savings providing for changes of Articles 1 and 2 in a way to include the following provisions regarding savings on: (i) gross wages and allowances through 10 percent cuts and (ii) employees' allowances by introducing a ceiling of 1 percent of the average wage on meal allowances and lowering the vacation allowance to 50 percent of the average wage from 75 percent of the individual wage. Until the Amendments and Changes to the Law on Savings become effective, the Federation 
government has passed, as a temporary measure, a decision on coefficient cuts across wage grades of all budget users.

15. Republika Srpska adopted a rebalanced budget for 2009 by December 31, 2009 which incorporated lower overall spending.

16. We will continue fiscal consolidation in 2010. To this end, we will aim at a general government deficit of $4 \frac{1}{2}$ percent of GDP. Our adjustment efforts will focus on controlling current expenditure, thus allowing space for spending on much-needed infrastructure. Wages in the public sector have grown very rapidly over the past few years and we are committed to wage restraint across all levels of government. We are also planning comprehensive structural fiscal reforms to return public finances to a sustainable path.

17. On the revenue side, we have already approved a Law on Excises, which will lead to a full harmonization of excises on tobacco by 2015 with those stipulated in the EU directives. On January 1, 2010, these excises increased again (with an estimated impact KM 120 million— 0.5 percent of GDP).

18. In 2010, the Institutions of Bosnia and Herzegovina will continue to implement restrictive wage policy based on legislation amended in 2009. Total spending in the 2010 budget of $\mathrm{BiH}$ Institutions will be slightly lower in comparison to the 2009 budget. As a result of a drawdown in deposits accumulated in 2008 and 2009, to finance part of the expenditures in 2010 budget, deficit will reach 0.8 percent of GDP (KM 194 million).

19. To address the weaknesses in the current system of public wages and transfers on a lasting basis, the Federation Government has elaborated a new draft law on wages and allowances for civil servants in all levels of government and draft legislation regulating social sector. These will allow a further reduction in the wage bill and keeping social transfers at the level of the rebalanced 2009 budget. As a result, the consolidated budget deficit will go down to KM 439 million in 2010.

20. The Federation Government shall undertake, in consultation with the World Bank, comprehensive reforms of the system of rights-based benefits, with the objective of better targeting through means-testing. We intend to: (i) introduce means-testing for acquisition of social benefit rights for disabled civilians, civilian war victims, and war-disabled (from January 1, 2011), and income tests for war medal holders (from May 1, 2010); (ii) link increases in all allowances to inflation, rather than average salary increases; and (iii) pass a law to eliminate the special benefits for unemployed demobilized soldiers, effective May 1 , 2010 (prior action - already met). We will reform privileged pensions (structural benchmark, end-March 2010), specifically: (i) pension rights of war disabled people and demobilized soldiers; (ii) rights to pensions under favourable conditions of military insurees of $\mathrm{FBiH}$ Armed Forces, civil servants and employees of the former Federal Ministry of Defence. We will consult with the IMF on any new proposed legislation in the area of rights-based 
benefits and ensure that it is consistent with the goal of fiscal sustainability and the objectives of the reform of these benefits. Specifically, any reintroduction of benefits for demobilized soldiers currently under consideration will not feature cash benefits, special pensions, housing loans or subsidized provision of housing.

21. These reforms will be supported through amendments to the following existing laws:

- Law on Audit of Rights of Beneficiaries Entitled to Defence-Invalid Protection (already adopted by parliament). Audits have started on January 1, 2010 and the disqualified beneficiaries will see their benefits cut immediately. The results of the audits will be published on a quarterly basis in the government's website, along with the estimates of realized monthly savings (continuous structural benchmark).

- Amendments to the Law on Rights of War Veterans and Members of their Families.

- Amendments to the Law on Rights of War Medal and Order Holders to become effective May 1, 2010;

- Law on Social Protection Basis and Social Security Minimum; Law on Basic Rights of Individuals with Disabilities; Law on Civilian War Victims by March 31, 2010;

- Framework Law on Targeting of Cash Benefits was adopted by Parliament (prior action).

- Law on Preferential Retirement of War Insurees which would unify all the FBiH Government provisions on preferential conditions for acquisition of rights to age retirement of military insurees of $\mathrm{FBiH}$ Armed Forces, civil servants and employees of the former Federal Ministry of Defence (Provision I, II and III). The purpose of the amendment will be to reduce the amounts paid out for privileged pensions (by tightening eligibility criteria and bringing the average amount closer to the average amount of regular pensions) and align the total cost with the resources earmarked for this purpose. This will help safeguard the financial integrity of the public pension system, on which the most vulnerable groups of society rely for income.

- To advance the transition to a means-tested system of social benefits, we will undertake the comprehensive property and revenue census, and introduce audits of property status for all the holders of civilian and war veteran rights by January 1, 2011.

22. The Government of the Federation will establish a centralised system of registration, control, and collection of taxes and contributions. This system will help improve implementation of laws and compliance with laws and regulations. For this purpose, we have 
adopted the Law on Fiscal Systems regulating record keeping and control of sales through fiscal systems.

23. The Federation Government will adopt a comprehensive Law on Wages to establish a fully harmonized, comprehensive and transparent remuneration system across all levels of government (structural benchmark, end-March 2010). All allowances and contributions will be consolidated in the base wage. This law will prescribe payment classes and coefficients for the categories of elected officials, managers, advisors, civil servants and police officers. The base will be determined by Government in consultation with the Trade Union, in accordance with the transparency principle.

24. The Federation Government recognises the need to change the budget process to ensure that adopted laws are adequately financially supported. For this purpose, we will be working toward adoption of a law on fiscal responsibility. In the meantime, amendments to the Law on the Budget have been adopted. The purpose of the amendments is to ensure that no legislation can be adopted without a full analysis of its fiscal implications and financing. This will rule out adoption of legislation for which adequate funding has not been identified.

25. The Government of Republika Srpska adopted a 2010 budget envisaging a consolidated deficit of KM 497 million (2 percent of GDP). Substantial cuts are envisaged for the wage bill: (i) a wage cut of KM 3 million compared to the 2009 budget rebalance will be carried out through amendments and changes of the RS Law on wages of government employees, Law on wages of Ministry of Interior employees, of those employed with correction institutions and court police as well as the Law on wages of those employed in education and culture or by Government decision; (ii) wage cuts to the employees in local administration units of KM 8.5 million in 2010 compared to the 2009 budget execution; (iii) wage cuts to the extra-budgetary funds employees (PIO, Health Fund, Child Protection Fund and Employment Fund) of KM 3.7 million compared to the 2009 budget execution; and (iv) wage cuts to PE"RS Roads" employees of KM 0.3 million compared to the 2009 budget execution.

26. Savings of KM 40 million will be realized on extra-budgetary funds: (i) the Pension Fund will save KM 25 million in line with the Pension System Reform Strategy and Restoration of the first mandatory insurance pillar; (ii) the Health Fund will save KM 15 million in health system costs; (iii) the deficit of the PIO Fund will be reduced by clearing the arrears of the RS budget as pursuant to the Protocol on mutual reconciliation of obligations and claims for war veterans' pension contributions (dated July 12, 2007) through escrow account payments-KM 38 million. Also savings in consolidated balance of KM 10 million are envisaged.

27. Republika Srpska has already amended and changed the Law on rights of war veterans and families of deceased soldiers and the Law on protection of the civil victims of 
the war as envisaged under the World Bank DPL project. The RS National Assembly also amended and changed the Law on pension and disability insurance and the Pension System Reform Strategy will be adopted by end-March 2010 (structural benchmark).

28. The Entity governments understand that our adjustment program may have an impact on the vulnerable groups of our population. Thus, the envisaged reforms are critical to ensuring that financial public support for households is better targeted toward the most vulnerable groups of society, and that financial integrity of public pension and unemployment insurance schemes does not become jeopardized.

\section{Financial Sector Policies}

29. The banking system has been able to withstand the shock of the global financial crisis. However, nonperforming loans have increased from 3 percent of assets at end 2008 to 5.8 percent at end December 2009, and profitability has declined. The two banking agencies are closely monitoring banking sector developments and ensure that banks continue to have adequate capital. To this end, banks have been instructed to retain profits and build up their buffers to prevent capital depletion. The banking agencies will ensure that banks have a forward-looking capital plan that will show how any potential deterioration in capital levels will be addressed and the banking agencies and the banks will review such plans periodically, to account for changing macroeconomic environment.

30. Parent banks have also pledged to continue to support their subsidiaries in $\mathrm{BiH}$ and more specifically to maintain their exposure to $\mathrm{BiH}$. The $\mathrm{CBBH}$ has received all 9 bilateral commitment letters from the parents of, mainly large, foreign-owned banks, confirming their commitments made in Vienna in June 2009 and Sarajevo in September 2009. The CBBH and the Banking Agencies are in the process of monitoring the parent banks' commitments. To help monitor the level of parent bank exposure to $\mathrm{BiH}$, the parent banks have been requested to provide comprehensive data on their exposures on a regular basis. In addition, bilateral discussions with banks will be initiated to review their capital adequacy, on the basis of stress tests to be finalized by the $\mathrm{CBBH}$ in cooperation with the two banking agencies.

31. We continue to improve our framework for crisis preparedness and management. To this end we have established a Standing Committee for Financial Stability (SCFS), which consists of members of the Fiscal Council, the $\mathrm{CBBH}$, the two banking agencies, and the Deposit Insurance Agency. A Memorandum of Understanding that establishes the formal framework of cooperation among the various parties has already been signed. We will be meeting on a regular basis to discuss and exchange information related to financial stability.

32. We are also continuing to improve our deposit insurance scheme to ensure continued confidence in our banking system. We have amended the deposit insurance regulation to enable all banks, regardless of the bank's ownership, to become a member of the deposit 
insurance scheme if the bank fulfills the necessary prudential criteria (structural benchmark for end-February 2010). In addition, we have signed an agreement with EBRD on access to emergency credit.

\section{Other}

33. We have already made important progress in improving the quality of statistics, particularly of the government accounts with the objective of compiling data harmonized with Eurostat and the IMF's Government Statistics guidelines. Under the umbrella of the Fiscal Council, we created a coordinating group with the task of collecting and consolidating the fiscal statistics from all levels of government in $\mathrm{BiH}$. We will ensure timely submission of all fiscal statistics by lower levels of government in the two Entities. We will make progress towards improving data collection and reconciliation of external grants and loan disbursements at the level of donors, state, and Entities. We will also broaden the coverage of reporting on fiscal execution to include foreign-financed projects and off-budget spending from escrow accounts in general government fiscal accounts in the two Entities.

34. On the basis of the conclusions of the updated safeguard assessment of the $\mathrm{CBBH}$, we are planning to: (i) revise the Audit Committee charter to include into its responsibilities an oversight of the external audit process and the requirement that at least one member of the Committee is an expert in accounting and/or audit issues; and (ii) ensure that audit procedures for FY2009 include confirmation that foreign assets are not pledged.

35. The program will continue to be monitored through quarterly reviews, prior actions, quantitative performance criteria, and structural benchmarks. Revised quantitative targets for 2010 are set out in Table 2; and structural benchmarks are set out in Table 3. We request that the end-March and end-June 2010 targets be established as performance criteria. The understandings between the authorities of Bosnia and Herzegovina and IMF staff regarding the quantitative performance criteria described in this memorandum are further specified in the TMU attached to this memorandum.

36. IMF resources under the arrangement will be disbursed to the Central Bank of Bosnia and Herzegovina, which acts as the fiscal agent for $\mathrm{BiH}$, and credited to an account of the State. The resources will be allocated to the two Entity budgets on the customary $2 / 3: 1 / 3$ split. 
$/ \mathrm{s} /$

Nikola Špirić

Chair

of the Council of Ministers

Bosnia and Herzegovina

/s/

Dragan Vrankić

Minister of Finance

of $\mathrm{BiH}$ Institutions

Bosnia and Herzegovina

/s/

Kemal Kozarić

Governor

Central Bank of Bosnia and Herzegovina
$/ \mathrm{s} /$

Mustafa Mujezinović

Prime Minister

Federation of Bosnia

and Herzegovina

/s/

Vjekoslav Bevanda

Minister of Finance

Federation of Bosnia

and Herzegovina
$/ \mathrm{s} /$

Milorad Dodik

Prime Minister

Republika Srpska

/s/

Aleksandar Džombić

Minister of Finance

Republika Srpska

Attachment 


\section{ATTACHMENT II. TeChNiCAL Memorandum OF UndERSTANDing}

\section{BOSNIA AND HERZEGOVINA}

\section{Technical Memorandum of Understanding on Definitions and Reporting Under the 2009-12 Economic Program}

March 5, 2010

This memorandum sets out the understanding between the government of Bosnia and Herzegovina and the IMF mission regarding the definitions of quantitative and structural performance criteria and targets for the stand-by arrangement (Tables 1-3) as well as data reporting requirements for program monitoring (Table 5).

\section{DEFINITIONS}

In the following definitions, the end-quarter test dates apply to the last working day of each quarter for both banking and budgetary statistics.

\section{A. Ceiling on the Cumulative Change in Net Credit from the Banking System to the General Government}

\section{Definitions}

- The general government is defined to include the governments of the State, the Republika Srpska Entity (RS), the Federation of Bosnia and Herzegovina Entity (Federation) and the District Brcko. The Federation government is defined to include the central government, the cantonal governments, the municipal governments, the extrabudgetary funds and the road fund. The RS government is defined to include the central government, the municipal governments, the extrabudgetary funds and the road fund. Extrabudgetary funds include, but are not limited to, the pension funds, health funds, unemployment funds, and children's fund in the two Entities. Any new budgetary and extra budgetary funds, created during the program period will also be included in the definition of the general government consistent with the definitions of the IMF Manual on Government Finance Statistics 2001. The BIH authorities will inform IMF staff of the creation of any such new funds.

- The banking system consists of the Central Bank of Bosnia and Herzegovina (CBBH) and the commercial banks in both Entities and the District of Brcko.

- Net credit of the banking system to the general government (net bank claims on general government) is defined as all banking system claims on general government (e.g. loans, 
securities, bills, and other claims in both convertible marka and foreign currencies) minus general government claims on the banking system (deposits, loans and other claims, including deposits in entities' escrow accounts) as defined in the Table 4 below. For program purposes, those components of claims that are denominated in foreign currencies will be converted into convertible marka at current exchange rates.

\section{Application of performance criteria}

- The value of net bank claims on general government will be monitored from the accounts of the banking system, as compiled by the $\mathrm{CBBH}$, and supplemented by information provided by the Ministries of Finance of each Entity and the State. Table 4 shows the banking system net claims on the general government as of end-December 2009.

- The ceilings on the cumulative change in net bank claims on general government will be defined, for each test date, as the cumulative change from the level existing on December 31 of the previous year.

- The ceilings on the cumulative change in net bank claims on general government will be defined in terms of three sub-ceilings that, together with the net bank claims on the District of Brčko, ${ }^{1}$ sum to the ceiling for the general government. These sub-ceilings will be on the cumulative change in net bank claims on the government of the State, the governments of the Federation of Bosnia and Herzegovina and of the Republika Srpska. For the purposes of program monitoring, compliance with the ceiling on net bank claims on general government will require that each of these three sub-ceilings be observed independently.

\section{Adjustors to performance criteria}

- $\quad$ The targets on net bank claims on general government will be adjusted upward (downward) ${ }^{2}$ by the full amount of any shortfall (surplus) in programmed disbursements of budget support loans and grants. Program budget support disbursements are defined as external disbursements from official creditors (e.g., World Bank, IMF, and European Commission) used for financing of general government budget deficits.

\footnotetext{
${ }^{1}$ The net bank credit to the District of Brčko is not monitored individually because of its small size.

${ }^{2}$ In the case of both positive and negative targets on net bank claims on general government, upward means resetting of the target to an arithmetically bigger number, whereas downward means resetting of the target to an arithmetically smaller number.
} 
The targets on net bank claims on general government will be adjusted upward (downward) ${ }^{3}$ by the amount by which reported change in float is arithmetically smaller (greater) than its targets in the fiscal program. Float is defined as accrued but unpaid purchases of goods and services, wages and salaries, pensions, social benefits, and investments that are not in arrears (as defined in the text below). The upward adjustment is limited to 10 percent of the absolute value of the respective change-infloat target.

$\mathrm{BiH}$ : General Government Change in Float, 2009 (In millions of KM)

\begin{tabular}{|c|c|}
\hline & $\begin{array}{r}2009 \\
\text { Dec } \\
\end{array}$ \\
\hline Change in float ( (1)-(2)-(3) ) & 180 \\
\hline State government & 0 \\
\hline $\mathrm{FBiH}$ government & 113 \\
\hline RS government & 67 \\
\hline District Brcko & 0 \\
\hline (1) Change in arrears and float & 180 \\
\hline State government & 0 \\
\hline FBiH government & 113 \\
\hline RS government & 67 \\
\hline District Brcko & 0 \\
\hline (2) External debt service arrears & 0 \\
\hline State government & 0 \\
\hline FBiH government & 0 \\
\hline RS government & 0 \\
\hline District Brcko & 0 \\
\hline (3) Domestic arrears & 0 \\
\hline State government & 0 \\
\hline $\mathrm{FBiH}$ government & 0 \\
\hline RS government & 0 \\
\hline District Brcko & 0 \\
\hline
\end{tabular}

\section{B. Operation of the Central Bank of Bosnia and Herzegovina}

Under the Central Banking Law and the program, the $\mathrm{CBBH}$ is required to ensure that the value of its domestic liabilities does not exceed the convertible marka counter-value of its net foreign exchange reserves. Furthermore, the $\mathrm{CBBH}$ will pay a dividend only if its initial capital and general reserves exceed 5 percent of its monetary liabilities.

\section{Definitions}

- Net foreign exchange reserves of $\mathbf{C B B H}$ are defined as the value of foreign assets less the value of foreign liabilities, including short-term liabilities denominated in convertible currencies or convertible marka.

- $\quad$ Foreign assets are defined to include: (i) any gold, other precious metal and stones held by or for the account of the Central Bank; (ii) any banknotes and coins in freely convertible foreign currency held by or for the account of the Central Bank; (iii) convertible foreign exchange notes; (iv) credit balances in convertible foreign exchange - including SDRs - on the books of foreign central banks or other financial institutions; (v) liquid debt securities issued by the government and the central bank of the country on whose currency the securities are denominated; and (vi) officially

\footnotetext{
${ }^{3}$ In the case of both positive and negative targets on net bank claims on general government, upward means resetting of the target to an arithmetically bigger number, whereas downward means resetting of the target to an arithmetically smaller number.
} 
guaranteed forward and repurchase contracts of different types providing for future payments in convertible foreign exchange by nonresidents. Excluded are (i) assets in nonconvertible currencies; (ii) any assets that are pledged, collateralized, or otherwise encumbered; (iii) claims on residents; and (iv) foreign exchange claims arising from derivatives in foreign currencies vis-à-vis domestic currency.

- $\quad$ Foreign liabilities are defined to include: (i) foreign exchange and convertible marka balances on the books of the $\mathrm{CBBH}$ due to nonresidents, including foreign central banks and international financial institutions; (ii) credit balances due to foreign central banks, governments, international organizations, and foreign financial institutions; (iii) forward and repurchase contracts of different types providing for future payments in foreign exchange by the $\mathrm{CBBH}$ to nonresidents; and (iv) any other liabilities due to nonresidents.

- $\quad$ Monetary liabilities are defined as the sum of (a) currency in circulation, (b) credit balances of resident banks at the $\mathrm{CBBH}$, and (c) credit balances of other residents at the $\mathrm{CBBH}$.

- $\quad$ Capital and reserves are defined as (a) initial capital, (b) accumulated profits of the CBBH since the beginning of its operation on August 11, 1997, (c) shares, (d) other reserves.

- $\quad$ Free reserves of the $\mathbf{C B B H}$ are defined as foreign exchange reserves not utilized as backing for the currency. They therefore consist of the stock of $\mathrm{CBBH}$ net foreign exchange reserves less the stock of CBBH monetary liabilities.

- $\quad$ Foreign currency holdings will be converted into convertible marka at the exchange rates of April 30, 2009, as published in the IMF International Financial Statistics. Valuation changes will therefore be monitored from the accounts of the $\mathrm{CBBH}$, with information on net foreign assets provided monthly by the $\mathrm{CBBH} .{ }^{4}$

\footnotetext{
${ }^{4}$ At end-April 2009, one SDR unit was equal to 1.1283 euro, or to 1.4978 U.S. dollars.
} 


\section{Ceiling on External Payment Arrears}

\section{Definitions}

- External payment arrears are defined as overdue debt service arising in respect of debt obligations incurred directly or guaranteed by the general government, except on debt subject to rescheduling or restructuring.

- Debt obligations are defined as all current liabilities, which are created under a contractual arrangement through the provision of value in the form of assets (including currency) or services, and which require the general government to make one or more payments in the form of assets (including currency), at some future point(s) in time to discharge principal and/or interest liabilities incurred under the contract. In effect, all instruments that share the characteristics of debt as described above (including loans, suppliers' credits and leases) will be included in the definition and be subject to the ceiling. The definition of general government is as described above.

\section{Application of performance criteria}

- The ceiling on the change in external payments arrears applies to the change in the stock of overdue payments on medium- and long-term debt contracted or guaranteed by the State, the Federation, and the Republika Srpska. This criterion will apply continuously.

- The limit on the change in external payments arrears also applies to the change in the stock of overdue payments on short term debt in convertible currencies with an original maturity of up to and including one year. The limit excludes reductions in connection with rescheduling of official and commercial debt and debt buy back. Accumulation of new external arrears is prohibited under the program.

\section{Ceiling on Domestic Expenditure Arrears}

\section{Definition}

Expenditure arrears are defined as the difference between payment obligations due, and actual payments made. They can arise on any expenditure item, including transfers, debt service, wages, pensions, energy payments and goods and services. Expenditure arrears for goods and services to suppliers are defined as obligations to suppliers, which are due but not paid for more than 45 days as defined in $\mathrm{BiH}$ organic Budget law, and are nondisputed. Arrears between the Entity central government budgets and local government, and extrabudgetary funds are not counted towards the expenditure arrears' ceiling on the general government. 


\section{Application of performance criteria}

The ceiling on accumulation of domestic payment arrears applies to obligations of the State, the Federation, and the Republika Srpska. This criterion will apply continuously.

\section{E. Contracting or Guaranteeing of New External Debt}

Governments will consult with the IMF before contracting or guaranteeing any new external debt.

\section{Definitions}

- The term "debt" is defined to include all current liabilities, which are created under a contractual arrangement through the provision of value in the form of assets (including currency) or services, and which require the general government to make one or more payments in the form of assets (including currency), at some future point(s) in time to discharge principal and/or interest liabilities incurred under the contract. In effect, all instruments that share the characteristics of debt as described above (including loans, suppliers' credits and leases) will be included in the definition. The definition of general government is as described above.

- New nonconcessional external debt is defined as including all debt (as defined above) contracted or guaranteed by the general government or the CBBH during the program period that is not on concessional terms.

- Concessional loans are defined as those with a grant element of at least 35 percent of the value of the loan, using currency-specific discount rates based on the commercial interest rates reported by the OECD (CIRRS). The average CIRRs over the last ten years--plus a margin reflecting the repayment period (1 percent for repayment period of 15-19 years; 1.15 percent for repayment period of 20-29 years; and 1.25 percent for repayment period of 30 years or more) — will be used as discount rates for assessing the concessionality of loans of a maturity of at least 15 years. For loans with shorter maturities, the average CIRRs of the proceeding six-month period (plus a margin of 0.75 percent) will be used.

- Short-term debt is defined as debt contracted or guaranteed by the general government with an original maturity of up to and including one year. 


\section{Application of performance criteria}

The ceiling on contracting new short-term external nonconcessional debt applies to obligations of the State, the Federation, and the Republika Srpska. This criterion will apply continuously.

\section{Data Reporting}

The Bosnia and Herzegovina authorities will report the following data to the Fund within the time limits listed below. The authorities will also provide, no later than the first week of each month, a summary of key macroeconomic policy decisions taken during the previous month; a summary of regulatory changes in the area of banking and financial sector, report any revisions to monthly and annual fiscal reports as well as any amendments to the Entity and state budget and local government budgets within a week after their approval.

Any revisions to past data previously reported to the Fund will be reported to the Fund promptly, together with a detailed explanation. The data will be provided in an electronic form.

All magnitudes subject to performance criteria or indicative targets will be reported in millions of convertible marka where the corresponding target is in convertible marka, or in millions of euro where the target is in euro.

The Bosnia and Herzegovina authorities will supply the Fund with any additional information that the Fund requests in connection with monitoring performance under the program on a timely basis. 
Table 1. Bosnia and Herzegovina: Performance Criteria Under the 2009-12 Stand-By Arrangement, 2009 (In millions of $\mathrm{KM}$ )

\begin{tabular}{|c|c|c|c|c|c|c|}
\hline & \multirow{4}{*}{$\begin{array}{c}\text { End-year stock } \\
2008 \\
\text { December } \\
\text { Actual }\end{array}$} & \multirow{2}{*}{\multicolumn{5}{|c|}{$\begin{array}{l}\text { Cummulative flow within the calendar year } \\
2009\end{array}$}} \\
\hline & & & & & & \\
\hline & & \multirow{2}{*}{$\frac{\text { June }}{\text { Actual }}$} & \multicolumn{2}{|c|}{ September } & \multicolumn{2}{|c|}{ Dec } \\
\hline & & & Program & Actual & Program & Actual \\
\hline \multicolumn{7}{|l|}{ Ceiling on accumulation of net credit of the banking system to: ${ }^{1}$} \\
\hline $\begin{array}{l}\text { General government } \\
\text { of which: }\end{array}$ & $-2,338$ & 261 & 476 & 156 & 676 & 309 \\
\hline State government & -412 & -89 & 44 & -69 & 44 & -30 \\
\hline RS government & $-1,109$ & 285 & 424 & 398 & 536 & 523 \\
\hline Federation government & -737 & 86 & 15 & -161 & 108 & -191 \\
\hline $\begin{array}{l}\text { Ceiling on new guarantees and the assumption of enterprise } \\
\text { debt to banks by the State, Federation and RS governments }{ }^{2}\end{array}$ & $\ldots$ & 0 & 0 & 0 & 0 & 0 \\
\hline Ceiling on accumulation external debt service arrears ${ }^{2}$ & $\cdots$ & 0 & 0 & 0 & 0 & 0 \\
\hline $\begin{array}{l}\text { Ceiling on contracting new short-term external } \\
\text { nonconcessional debt }{ }^{2}\end{array}$ & $\ldots$ & 0 & 0 & 0 & 0 & 0 \\
\hline \multicolumn{7}{|l|}{ Ceiling on accumulation of domestic arrears of: ${ }^{2}$} \\
\hline State government & $\ldots$ & 0 & 0 & 0 & 0 & 0 \\
\hline RS government & $\ldots$ & 0 & 0 & 0 & 0 & 0 \\
\hline Federation government & $\ldots$ & 0 & 0 & 0 & 0 & 0 \\
\hline
\end{tabular}

${ }^{1}$ Cumulative within each calendar year. Equal to the sum of the three listed sub-ceilings plus the net bank credit to the

District of Brčko, which is not monitored individually due to its small size.

${ }^{2}$ Continuous.

Table 2. Bosnia and Herzegovina: Performance Criteria Under the 2009-12 Stand-By Arrangement, 2010 (In millions of $\mathrm{KM}$ )

\begin{tabular}{|c|c|c|c|c|c|}
\hline & \multirow{3}{*}{$\begin{array}{c}\text { Stock } \\
2009 \\
\text { December }\end{array}$} & \multicolumn{4}{|c|}{ Cumulative flow since the beginning of the referenced year } \\
\hline & & \multicolumn{4}{|c|}{2010} \\
\hline & & March & June & September & December \\
\hline & Actual & Program & Program & Ind target & Ind target \\
\hline \multicolumn{6}{|l|}{ Ceiling on accumulation of net credit of the banking system to: ${ }^{1,2}$} \\
\hline $\begin{array}{l}\text { General government } \\
\text { of which: }\end{array}$ & $-2,029$ & 333 & 580 & 759 & 845 \\
\hline State government & -442 & 20 & -11 & 75 & 122 \\
\hline RS government & -586 & 251 & 429 & 564 & 638 \\
\hline Federation government & -928 & 61 & 164 & 122 & 91 \\
\hline $\begin{array}{l}\text { Ceiling on new guarantees and the assumption of enterprise debt to banks } \\
\text { by the State, Federation and RS governments }{ }^{3}\end{array}$ & $\ldots$ & 0 & 0 & 0 & 0 \\
\hline Ceiling on accumulation external debt service arrears ${ }^{3}$ & $\ldots$ & 0 & 0 & 0 & 0 \\
\hline $\begin{array}{l}\text { Ceiling on contracting new short-term external } \\
\text { nonconcessional debt }{ }^{3}\end{array}$ & $\ldots$ & 0 & 0 & 0 & 0 \\
\hline \multicolumn{6}{|l|}{ Ceiling on accumulation of domestic arrears of: ${ }^{3}$} \\
\hline State government & $\ldots$ & 0 & 0 & 0 & 0 \\
\hline RS government & $\ldots$ & 0 & 0 & 0 & 0 \\
\hline Federation government & $\ldots$ & 0 & 0 & 0 & 0 \\
\hline
\end{tabular}

\footnotetext{
${ }^{1}$ Equal to the sum of the three listed sub-ceilings plus the net bank credit to the District of Brčko, which is not monitored individually due to its small size.

${ }^{2}$ The targets on banking system net claims the general government will be adjusted upward (downward) by the full amount of any shortfall (surplus) in programmed disbursements of budget support loans and grants; and will also be adjusted upward (downward) by the amount by which reported change in float is arithmetically smaller (greater) than its targets in the fiscal program. The upward adjustment is limited to 10 percent of the absolute value of the respective change-in-float target (see Technical Memorandum of Understanding on Definitions and Reporting Under the 2009-12 Economic Program).

${ }^{3}$ Continuous.
} 
Table 3. Bosnia and Herzegovina: Performance for the First Review under the 2009-12 Stand-By Arrangement

Status
Target date

\section{Quantitative performance criteria}

1. Ceiling on accumulation of net credit of the banking system to: general government

December 2009

State government

RS government

Federation government

2. Ceiling on new guarantees and assumption of enterprise debt to banks by the State, Federation and RS governments

3. Ceiling on accumulation of external payment arrears

4. Ceiling on contracting new short-term external nonconcessional debt

5. Ceiling on accumulation of domestic payment arrears

State government

RS government

Federation government

II. Current Structural Benchmarks

A. Continued adherence of the Currency Board Arrangement as constituted under the law

B. Fiscal Sector

1. Approve the rebalanced budgets by the Entity Parliaments

2. Agree on an action plan acceptable to the World Bank and IMF staffs to reform the system of rights-based transfers (Federation)

3. Submit to the Parliament a Law forbidding passing of unfunded legislation (Federation)

4. Publish on the State government's web site quarterly consolidated general government accounts with a 5 week lag

\begin{tabular}{|c|c|}
\hline & $\begin{array}{l}\text { observed } \\
\text { observed } \\
\text { observed } \\
\text { observed }\end{array}$ \\
\hline December 2009 & observed \\
\hline December 2009 & observed \\
\hline December 2009 & observed \\
\hline December 2009 & $\begin{array}{l}\text { observed } \\
\text { observed } \\
\text { observed }\end{array}$ \\
\hline continuous & observed \\
\hline end-August 2009 & observed \\
\hline nd-November 2009 & observed with delay \\
\hline nd-November 2009 & observed with delay \\
\hline continuous & $\begin{array}{c}\text { observed partially, with } \\
\text { delay }\end{array}$ \\
\hline
\end{tabular}

\section{Financial Sector}

1. Form a standing committee of financial stability and sign the MoU on financial stability, crisis preparedness and crisis management

2. The Deposit Insurance Agency to impose a principle of universal membership requirements, including for partially state-owned banks

III. Proposed New Conditionality Prior Actions

1. Approve by State and Entity Parliaments 2010 budgets consistent with the program, including supporting legislation

2. Enact by Entity Parliaments framework legislation in preparation for the transition to a meanstested system of rights-based benefits (Federation, RS)

3. Enact law to eliminate special unemployment benefits granted to demobilized soldiers effective May 1, 2010 (Federation)

\section{Structural Benchmarks}

1. Carry out eligibility audits for civil and war benefit recipients; publish results (quarterly within 4 weeks after the end of each quarter) of audits, including expected savings from disqualifications (Federation, RS)

2. Adopt by Parliament wage legislation consistent with the 2010 fiscal policy objectives (Federation)

3. Reform privileged pensions by entity governments (Federation, RS)

4. Prepare a strategy for pension reform by entity governments (Federation, RS)

met

met

met continuous

end-March 2010

end-March 2010

end-March 2010 
Table 4. Bosnia and Herzegovina: Net Claims of the Banking System on the General Government, as of December 31, 2009

(In millions of KM)

\begin{tabular}{|c|c|}
\hline Position & Stock \\
\hline Total net bank claims on the general government $((1)+(2))$ & $-2,029$ \\
\hline (1) Central bank claims on general government (net) & -398 \\
\hline Claims & 0 \\
\hline State government & 0 \\
\hline FBiH government ${ }^{1}$ & 0 \\
\hline RS government $^{2}$ & 0 \\
\hline District Brcko & 0 \\
\hline Deposits & 398 \\
\hline On-balance sheet deposits in $\mathrm{KM}^{3}$ & 50 \\
\hline State government ${ }^{4}$ & 48 \\
\hline FBiH government ${ }^{1}$ & 2 \\
\hline RS government $^{2}$ & 0 \\
\hline District Brcko & 0 \\
\hline Off-balance sheet deposits in foreign currency & 347 \\
\hline State government ${ }^{5}$ & 347 \\
\hline FBiH government & 0 \\
\hline District Brcko & 0 \\
\hline (2) Commercial bank claims on general government (net) & $-1,632$ \\
\hline Claims & 346 \\
\hline State government & 1 \\
\hline FBiH government ${ }^{1}$ & 36 \\
\hline RS government $^{2}$ & 303 \\
\hline District Brcko & 6 \\
\hline Deposits & 1,978 \\
\hline State government & 48 \\
\hline FBiH government ${ }^{1}$ & 962 \\
\hline RS government ${ }^{2,6}$ & 890 \\
\hline District Brcko & 78 \\
\hline
\end{tabular}

Source: $\mathrm{CBBH}$.

${ }^{1}$ Includes FBiH central government, cantons, municipalities, road fund, and social funds.

${ }^{2}$ Includes RS central government, municipalities, road fund, and social funds.

${ }^{3}$ Excludes on-balance sheet accounts at $\mathrm{CBBH}$ used for safekeeping on behalf of State and Entity governments of the proceeds from sale of general and special SDR allocations.

${ }^{4}$ The deposits of the State government, as reported by $\mathrm{CBBH}$, are adjusted to exclude the deposits of the Indirect Tax Administration (KM 33.65 million at end-September, 2009).

${ }^{5}$ Excludes the off-balance sheet account at $\mathrm{CBBH}$ used as a pass-through account for external debt servicing on behalf of Entity governments; and the off-balance sheet account at $\mathrm{CBBH}$ used for safekeeping on behalf of State and Entity governments of succession funds from the distribution of rights, obligations, assets and liabilities of the former Socialist Federal Republic of Yugoslavia among successor states.

${ }^{6}$ The deposits of the RS government are adjusted to exclude the deposits of investment funds managed by the RS Development Bank. Whereas the latter is not included in the definition of general government, some banks report the deposits of these investment funds as part of net bank credit to government. At end-September 2009, the amount of excluded deposits stood at KM 33.78 million. 
Table 5. Bosnia and Herzegovina: Data Reporting Requirements under the 2009 SBA

\begin{tabular}{|c|c|c|c|c|}
\hline & Data series & $\begin{array}{c}\text { Data } \\
\text { frequency }\end{array}$ & $\begin{array}{l}\text { Periodicity of } \\
\text { data reporting }\end{array}$ & Timeliness of data reporting \\
\hline I. & Daily data reporting & Daily & Weekly & Up to 14 working days after the end \\
\hline 1 & Gross international reserves & & & of each week, unless noted \\
\hline 2 & CBBH foreign exchange purchases and sales & & & \\
\hline II. & Monthly data reporting & Monthly & Monthly & Up to 4 weeks after the end of each \\
\hline 1 & The balance sheet of the $\mathrm{CBBH}$. & & & month, unless noted otherwise \\
\hline 2 & The commercial bank survey and monetary survey & & & \\
\hline 3 & Weighted average interest rates by bank and by type of loans & & & \\
\hline 4 & Banking sector credit to the general government (by level of & & & \\
\hline 5 & Government deposits in the banking sector & & & \\
\hline 6 & $\begin{array}{l}\text { Revenues, expenditures and financing data for central governments } \\
\text { (the State, and the Entity governments). Expenditures will include } \\
\text { those financed from deposits in the escrow accounts. }\end{array}$ & & & \\
\hline 7 & ITA revenues. & & & \\
\hline 8 & New external loans contracted or guaranteed by governments. & & & \\
\hline 9 & Report on inflows into and outflows from escrow accounts (FBiH, & & & \\
\hline 10 & $\begin{array}{l}\text { Transfers to the Entity Development Banks from the Entity central } \\
\text { governments. }\end{array}$ & & & \\
\hline III. & Quarterly data reporting & Quarterly & Quarterly & Up to five weeks after the end of \\
\hline 1 & Banking supervision: financial soundness indicators & & & each quarter, unless noted \\
\hline 2 & $\begin{array}{l}\text { Banking supervision: bank-by-bank commercial banks' summary } \\
\text { balance sheets and income statements and prudential data on loan } \\
\text { quality, liquidity, and exposures }{ }^{1}\end{array}$ & & & \\
\hline 3 & $\begin{array}{l}\text { Revenues, expenditures and financing data for municipalities (in both } \\
\text { entities), and cantons (in the Federation), and Brcko District }\end{array}$ & & & \\
\hline 4 & $\begin{array}{l}\text { Revenues, expenditures and financing data for the road funds in both } \\
\text { entities }\end{array}$ & & & \\
\hline 5 & $\begin{array}{l}\text { Revenues, expenditures and financing data for the extrabudgetary } \\
\text { funds (pension funds, health funds, unemployment funds and (in the } \\
\text { RS) the children's fund) }\end{array}$ & & & \\
\hline 6 & $\begin{array}{l}\text { Revenues, expenditures and financing data for consolidated BiH, } \\
\text { consolidated FBIH, consolidated RS }\end{array}$ & & & \\
\hline 7 & Financial statements of the RS Investment and Development Bank & & & \\
\hline 8 & $\begin{array}{l}\text { External debt service projections for current year; total, by creditor, by } \\
\text { level of government, and in original currency }\end{array}$ & & & \\
\hline 9 & $\begin{array}{l}\text { Newly issued government guarantees on external and domestic loans } \\
\text { contracted by public and private entities }\end{array}$ & & & \\
\hline 10 & $\begin{array}{l}\text { Newly contracted government external loans and degree of } \\
\text { concessionality (grant element); total, by creditor, by purpose } \\
\text { (project/budget support), original currency, and maturity }\end{array}$ & & & \\
\hline 11 & $\begin{array}{l}\text { External debt service payments (interest, amortization) by level of } \\
\text { government }\end{array}$ & & & \\
\hline 12 & $\begin{array}{l}\text { External loan and grants disbursements; by creditor, by level of } \\
\text { government, by purpose (project/budget support) and original } \\
\text { currency }\end{array}$ & & & \\
\hline 13 & $\begin{array}{l}\text { Stock of external debt for public sector, private nonbank sector, and } \\
\text { banking sector }\end{array}$ & & & \\
\hline 14 & Net exposure to $\mathrm{BiH}$ of foreign bank groups participating in the & & & \\
\hline 15 & $\begin{array}{l}\text { European Bank Coordination Initiative for } \mathrm{BiH}^{2} \\
\text { Stock of domestic government debt outstanding (by level of } \\
\text { government, type of obligation, and holder (bank and non-bank } \\
\text { sectors)); projected domestic government debt interest and } \\
\text { amortization payments (by level of government, type of obligation, } \\
\text { and holder) }\end{array}$ & & & \\
\hline 16 & $\begin{array}{l}\text { End-period stock of outstanding arrears and float during the } \\
\text { reference period by creditor and type of expenditure(wages, social } \\
\text { benefits, pension, goods and services, etc. ) }\end{array}$ & & & \\
\hline 17 & $\begin{array}{l}\text { Number of demobilized soldiers receiving unemployment benefits (by } \\
\text { canton), and amounts paid }\end{array}$ & & & \\
\hline
\end{tabular}

${ }^{1}$ Up to six weeks after the end of each quarter

${ }^{2}$ Upon request within eight weeks 
March 24, 2010

\section{IMF Completes First Review under Stand-By Arrangement with Bosnia and Herzegovina, Approves $€$ 138.4 million Disbursement}

The Executive Board of the International Monetary Fund (IMF) today completed the first review of Bosnia and Herzegovina's economic performance under a program supported by a 36-month Stand-By Arrangement (SBA). The completion of the review enables the immediate disbursement of an amount equivalent to SDR 121.75 million (about $€ 138.4$ million or US\$ 184.6 million), bringing total disbursements under the program to an amount equivalent to SDR 304.38 million (about $€ 345.9$ million or US\$ 461.4 million).

The SBA was approved on July 8, 2009 (see Press Release No.09/258). Following the Executive Board's discussion, Mr. Murilo Portugal, Deputy Managing Director and Acting Chair, stated:

"The authorities are to be commended for their satisfactory policy implementation under the Stand-by Arrangement amid a difficult economic and political environment. Strong efforts will continue to be needed to ensure fiscal and external sustainability, and to provide the basis for robust, sustainable growth. The authorities are committed to carefully monitor program implementation and adjust policies as necessary.

“The program's fiscal deficit objective for 2010 has been adjusted to strike a balance between accommodating the still weak economic situation and preserving the medium-term consolidation objectives. The envisaged measures aim to secure a permanent reduction in recurrent government spending, thus providing more space for much-needed capital expenditure. The reform of social benefits, including through better targeting, is crucial for safeguarding social protection and ensuring that these benefits reach the most vulnerable groups of the population. The authorities are also committed to reforming the pension and wage systems, and improving the budget process and public finance management. 
"The authorities are committed to continue to carefully monitor Bosnia and Herzegovina's competitiveness. Structural impediments to growth will be addressed through reforms aimed at enhancing productivity and fostering private sector development.

"The financial sector has coped well with the crisis. The commitment of foreign parent banks to maintain their exposure vis-à-vis Bosnia and Herzegovina and to keep their subsidiaries well capitalized has had a stabilizing effect. The recent enhancement of the monitoring of financial stability and improvements in crisis preparedness and management should increase the effectiveness of the authorities' response to future challenges. Continued vigilance and strengthened cooperation between the central bank and banking agencies will be important." 


\section{Statement by Mr. Bakker and Mr. Tomic on Bosnia and Herzegovina Executive Board Meeting 10/27 \\ March 24, 2010}

\section{Introduction}

1. The authorities of Bosnia and Herzegovina $(\mathrm{BiH})$ would like to thank staff for constructive policy discussions during the mission, the continued dialogue in the period after the visit, and the very helpful role the Fund has played in the Vienna Initiative. In addition, the authorities have benefited from the exemplary cooperation between WB and Fund staff.

2. While the counterfactual is hard to establish, it could be said that, so far, $\mathrm{BiH}$ has benefited from the IMF Stand-By Arrangement, at least, threefold: first, the IMF provided financing that helped mitigate the sharp fall in domestic and external demand; second, the initiated adjustment measures, some in the form of structural benchmarks, are key for securing long-term fiscal sustainability; and third, the program provided a strong signal for foreign banks to preserve their exposure and commitment to the $\mathrm{BiH}$ market. That said, the authorities remain aware that post-crisis progress depends on the continuation of the structural reforms, as high and increasing unemployment remains the major economic problem. Staff has presented an accurate description of both economic developments and future challenges.

\section{Program Implementation and macroeconomic developments}

3. The implementation of the Fund-supported program is on a satisfactory track, and all quantitative PCs, and major structural benchmarks have been met, albeit some with delay. The authorities remain committed to continuing this track record. With respect to the timely publication of fiscal data, the only structural benchmark fulfilled only partially, the authorities remain devoted to broadening the scope and shortening the time of making consolidated fiscal data publicly available. Delays in fulfilling some prior actions were used to gain further support of the wider public, as most of the adjustment measures consist of streamlining the entitlements provided during the upward cycle. Finally, the program performance should also be judged with a view to the general elections scheduled for October 2010.

4. Macroeconomic developments were mostly in line with the original program projections. Lower than expected growth and lower revenue outturn resulted in a 
slightly breached fiscal deficit objective for 2009. At the same time, a sharp reduction in imports, particularly of capital and durable goods, contributed to the narrowing of the external deficit. The latest data indicate a recovery of external demand, and this could be a sign of the crisis bottoming out. However, the speed of the recovery remains dependent on exogenous factors, including developments in the economies of major trading partners and a resumption of bank credit activities. A small positive growth is expected in 2010 .

\section{Monetary policy and the financial system}

5. The financial system, dominated by foreign-owned bank subsidiaries, withstood the impact of the global crisis. Although exposure of the foreign banks was slightly lower at the end of December 2009 than a year before, the banking system preserved stability, and deposits, after initial withdrawals, started recovering. The authorities established a standing committee on financial stability and improved crisis preparedness and risk management procedures. In addition, the deposit insurance regulation was changed and is now universal irrespective of the ownership structure. A credit line for strengthening the credibility of the increased deposit insurance was secured from the EBRD.

6. Credit expansion was negative, like elsewhere, as repaid loans exceeded new approvals. Similarly, nonperforming loans, although still at a comfortable level, have increased. In spite of these developments the capital adequacy ratio remained at a satisfactory level. $\mathrm{CBBH}$ and banking supervisory agencies have benefitted from MCM technical assistance, and are in the process of conducting stress tests. The monetary authorities remain committed to continuously monitoring the health of the financial system, including through bilateral discussions with banks.

7. The currency board arrangement (CBA), equally supported by market participants, the authorities and the broader public, remains an appropriate nominal anchor. The competiveness assessment by staff finds no evidence of misalignment. On the contrary, growing export market shares and low inflation expectations reinforce the overall impression of adequate competitiveness. In light of still present uncertainties related to a regional recovery, as well as depreciation among some trading partners, the authorities will continue to carefully monitor real effective exchange rate developments.

\section{Fiscal Policy}

8. Although the initial fiscal targets had to be somewhat relaxed partly because of revenue underperformance, the numerous measures adopted by all tiers of government helped maintain fiscal prudence by improving the expenditure structure. These measures were reflected in the 2009 supplementary as well as the adopted 2010 budgets. On top of expenditure reductions, additional savings will be achieved through improved legislation, most importantly the wage bill in the Federation $\mathrm{BiH}$. Similarly, reforms of social transfers through the introduction of means-testing in both entities will allow better targeting the most vulnerable. Enacted amendments to 
the budget law effectively rule out adoption of unfunded mandates.

9. The authorities are aware of the modest increase in the public debt to GDP ratio under the program until 2011, and remain determined to achieve a balanced budget over the medium term. More importantly, developing and implementing pension reform is considered as one of the priorities that will secure long-term fiscal sustainability.

\section{Going forward}

10. The program so far achieved the major objective of safeguarding macro stability and helping to initiate the needed structural reforms. Cognizant of the fact that continued success in achieving the program objectives critically depends on the implementation of the structural reforms, the authorities request approval of the first review. 